RỔ L Life Sciences Miscellaneous Publications

Royal Ontario Museum

\title{
A Systematic Illustrated
to Fossil Organic-walled \\ Dinoflagellate Genera
}

Darrah Artzner

Edward H. Davies

Gunter Dörhöfer

Armando Fasola

Geoffrey Norris

Silvana Poplawski

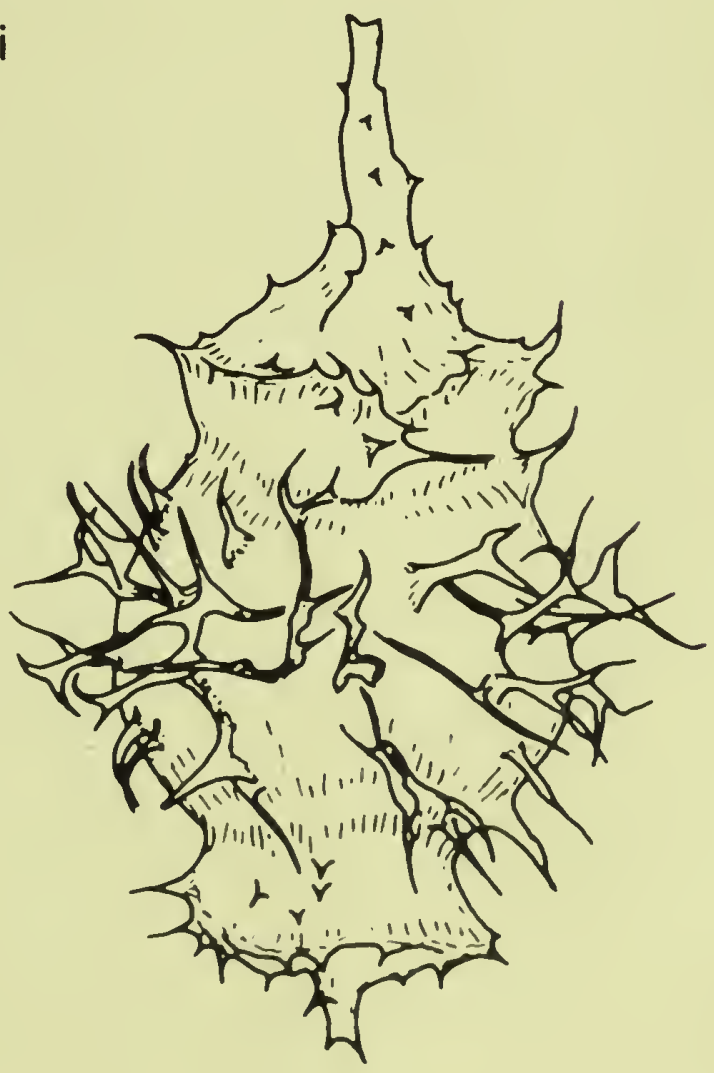


0 
DARRAH ARTZNER EDWARD H. DAVIES GUNTER DÖRHÖFER ARMANDO FASOLA GEOFFREY NORRIS SILVANA POPLAWSKI

\section{A Systematic Illustrated Guide to Fossil Organic-walled Dinoflagellate Genera}


The Royal Ontario Museum publishes three series in the Life Sciences:

LIFE SCIENCES CONTRIBLTIONS, a numbered series of original scientific publications including monographic works.

LIFE SCII:NCES OCCASIONAL. PAPERS, a numbered series of original scientific publications, primarily short and usually of taxonomic significance.

LIFE SCIENCES MISCELLANFOUS PL BLICATIONS, an unnumbered series of publications of varied subject matter and format.

All manuscripts considered for publication are subject to the scrutiny and editorial policies of the Life Sciences Editorial Board, and to review by persons outside the Museum staff who are authorities in the particular field involved.

LIFE SCIENCES EDITORIAL. BOARD

Senior Editor: I H MCANDREWS

Editor: R. D JAMES

Editor: C. MCGOWAN

DARRAH ART/NER and EIDWARD H DAVIES were postgraduate students in the Department of Geology, University of Toronto. GUNTIR DORHOFER was a postdoctoral fellow of the Depanment of Geology, University of Toronto. AR.MANDO FASOLA is a member of the Palynology Laboratory of the Department of Geology, University of Toronto. GEOFFREY NORRIS is a Research Associate in the Department of Botany, Royal Ontario Museum, and a Professor of Geology, University of Toronto. SILVANA POPLAwSKI is a member of the Palynology Laboratory of the Deparment of Geology, University of Toronto.

\section{Cover photo:}

Iriblasulata utinensis Originally described by Otto Wetzel in 1933 from a Cretaceous erratic flint in the Baltic region, this dinotlagellate cyst is now known from Maastrichtian sediments principally in North America and Europe.

\footnotetext{
Canadian Cataloguing in Publication I)ata

Main entry under title:

A Systematic illustrated guide to fossil organicwalled Dinoflagellate genera

(1afic sciences muscellaneous publications ISSN (xo82-5093)

Bıbliography: p.

ISIBN ()-88854-237-2

1 Dinotlagellata, Fossil - Identitication.

I Anzner. Darrah. II Royal Ontario Museum

III Series. Life sciences miscellaneous publication.

(21:774 D5.598
Q1.1 165.39
}

(1) The Royal Onlaris Museum, 1979

Ifx) Queen's Park, Toronto, Canada MSS 2 C6

I'RINTH:1) AND BOUND IN CANADA AT THI: ALGER PRESS

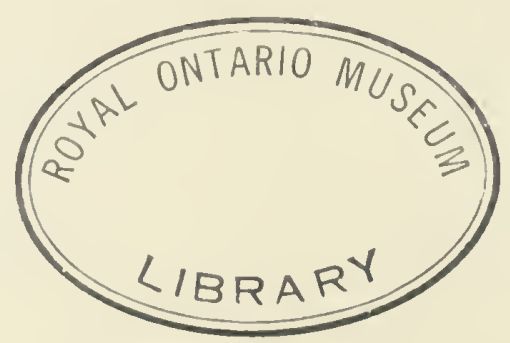




\section{Contents}

Abstract 5

Introduction 5

Abbreviations and Logograms 6

Classification 7

Order Peridiniales Haeckel, 18948

Order Dinophysidales Stein, 18839

Order Gymnodiniales, 18969

Nomenclature 9

How to Use the Guide 9

Alphabetical Check List of Families and Genera 10

Acknowledgements 13

Literature Cited 14 
Digitized by the Internet Archive in 2012 with funding from Royal Ontario Museum 


\title{
A Systematic Illustrated Guide to Fossil Organic-walled Dinoflagellate Genera
}

\begin{abstract}
The Guide assigns 276 genera of fossil dinoflagellates to the Orders Peridiniales, Dinophysidales, and Gymnodiniales. The Peridiniales are further subdivided into four suborders comprising 31 families. Each genus is illustrated by a line drawing at a standard magnification based in most cases on the illustration and description of the type species and holotype.
\end{abstract}

\section{Introduction}

The number of described fossil dinoflagellate taxa has increased dramatically since the mid-19th century (Downie and Sarjeant, 1965: Williams and Bujak, 1977a; Williams and Bujak, 1977b) with the last 10 to 15 years showing the greatest advance. During this period, however, taxonomic concepts have become stabilized and centre upon a few discrete characters which appear to be important for segregation of genera and higher level taxa (See Sarjeant, 1974, and Norris, 1978a, for a discussion of the development of higher level dinoflagellate cyst taxonomy since the 19th century.) Recent compilations (Evitt, 1975; Lentin and Williams, 1977b, 1978;) indicate in excess of 300 fossil genera and almost 2.000 fossil species of dinoflagellate cysts.

This explosion in fossil dinoflagellate taxonomy has rendered the Eisenack catalogue (Eisenack, 1964-1975) and the Fichier Micropaléontologique Général (Deflandre, and Deflandre-Rigaud, 1943-1974) essential tools for those attempting to trace original descriptions and illustrations of taxa and who do not have access to all the primary literature. Basionyms are almost exclusively used and few recombinations are referred to in those alphabetical listings of genera and species.

Our work facilitates the use of the existing catalogues and indices and improves understanding of the Class Dinophyceae by providing an illustrated guide to holotypes of type species of validly published fossil genera with organic-walled cysts. Generally, we include genera with sufficiently clear characters 10 allow placement in families, although a few assigned "Incertae Familiae" are also illustrated.

All genera are illustrated by line drawings, either as facsimile reproductions of original figures (some with magnification changes) or by drafting from published photographs. The quality of the drafted figure is linked to the quality and details visible on the original photograph. It is apparent that some holotypes are poorly preserved or displayed. This must be taken into account in any taxonomic assessment of a genus which, however, is not the purpose of this Guide.

Fossil dinoflagellate genera excluded from this Guide are those with calcareous or siliceous walls, and those with less than the minimum characters available for familial placement (with certain exceptions) or those of doubtful dinophycean affinity. Junior synonyms are also omitted. Taxa now considered of subgeneric status are not included. In general, we were conservative in the selection of genera for illustration. Holotypes or topotype material, in most cases, have not been studied directly, thus requiring considerable caution in the interpretation of salient morphologic features. We believe that on restudy, some of the omitted genera will be capable of placement into the taxonomic scheme. Precipitous placement at this stage, however, would not serve any useful purpose, even though it became apparent during the preparation of the Givide that several taxa require emendation or recombination. 


\section{Abbreviations and Logograms}

The families are listed herein with their salient morphologic features indicated by logograms (Norris, 1978a). Salient morphologic features of most fossil dinoflagellates, according to Norris (1978a), can be regarded as being dependent on up to six variables which are adequate for defining genera and higher taxa viz. degree of contraction, horns, archeopyle type, ornament distribution, special ornamental features, and tabulation. The following abbreviations are used for the variables in each category and are listed roughly in the order of ease of observation. They include terms used by Evitt et al. (1977), Norris (1978a), and by others that are listed in Williams, Sarjeant and Kidson (1973), together with some new terms that are discussed below. The terms selected for the variables are only some of the many available for describing dinoflagellate cyst morphology. They are adequate, however, for circumscribing taxonomically important features.

(i) degree of contraction (Text Fig. 1)

Pc proximate - cavate

$\mathrm{Pa}$ proximate - acavate (i.e. no pericoels developed)

Ap apteate

Sp spiniferate

$\mathrm{Ch}$ chorate

Ma marginate (see Fig. 165)

Some confusion is apparent in the usage of the term "proximochorate" as originally used by Downie and Sarjeant (1966: 15), for genera such as Spiniferites with low condensation ratios and sutural "outgrowths". The term suggests chorate cysts which have proximate characters. Yet, the main difference between proximate and chorate cysts is the development of a more or less spherical main body in the latter, whereas proximate cysts morphologically mimic the ambitus of the motile stage. Unfortunately, the term proximochorate has also been used for proximate cysts with low ornament, even though this type of cyst requires separate characterization. To remove this uncertainty and ambiguity, Norris (1978a) chose the term spiniferate, to indicate cysts with an essentially spheroidal main body (i.e. with no clear relationship to the presumed shape of the parent theca) and prominent sutural processes, which may be connected proximally by linear elements or distally by trabeculae, or both. The processes are typically short (low condensation ratio). For proximate cysts with ornamentation of reduced length (i.e. the main body has a clear relationship to the presumed shape of the parent theca) the term apteate was introduced by Dörhöfer and Davies (1979). Apteate ornament in most cases is related to the plate configuration, i.e. intra- or penitabularly arranged.

Recent work on rhaetogonyaulacinean genera (Dörhöfer and Davies, 1979) shows that the development of endoblasts is a variable feature. Two-layered (or more) proximate cysts may or may not develop endoblasts, without any change in overall morphology. Therefore, Dörhöfer (in press) differentiates between cavate and acavate proximate cysts (Text fig. 1). It may be necessary ultimately to revise the proximate-cavate and proximateacavate peridinialean families to express this variability more satisfactorily. At the moment, however, the distinction of phenotypic from genotypic variation in pericoelar development is difficult and its further application to taxonomy is not attempted here.

(ii) Horns (or unique processes in the cardinal positions)

ap apical horn

aa antapical horn

2aa two antapical horns

$2 \mathrm{cn}$ two cingular horns

$\mathrm{pc}$ one postcingular horn

$2 \mathrm{pc}$ two postcingular horns

(iii) Archeopyle type

A apical archeopyle

I intercalary archeopyle

P precingular archeopyle

\begin{tabular}{|c|c|c|c|c|}
\hline CAVATE & ACAVATE & APIEATE & SPINIFERATE & CHORATE \\
\hline \multicolumn{2}{|c|}{ PROXIMATE } & & \\
\hline
\end{tabular}

Text figure | Dinoflagellate cyst types based on degree of contraction. Refer to text for explanation. 
AIP epitractal archeopyle or archeopyle comprising some plates of each series in the epitract.

HA antapical archeopyle

DIS disintegration archeopyle

Disintegration archeopyles have been recognized and defined by Dörhöfer and Davies (1979) as forming by disintegration of the epitract, initiated by splitting in the mid-dorsal intercalary position (usually between the apical and intercalary series) and subsequent progressive loss of the neighbouring plates. This type of archeopyle is characteristic for the earliest dinoflagellates of the family Rhaetogonyaulacaceae.

These principal types of archeopyles are adequate for most family logograms. Lower taxononic levels require more elaborate formulas (see Norris, 1978a). We follow Norris (1978a: 303 ) in replacing the superscript bar in the archeopyle formula with round brackets in positions corresponding to each end of the bar.

(iv) Ornament distribution on the plate

sut sutural

pen penitabular

int intra-tabular (int-1 $=$ one process per plate; int $n=$ several processes per plate)

non non-tabular

abs absent

(v) Special ornamental features

trab trabeculate processes

pcel pericoelar connecting processes

akra akrate, i.e. ornament lacking or extremely reduced on cingulum

pcin pericingulate, i.e. sutural ornament exclusively or almost exclusively developed on cingulum

unpa unornamented pandasutural zone (or strongly reduced relative to intratabular elements elsewhere)

coro bearing a corona

(vi) Tabulation

The standard Kofoi. plate numeration system and formula as adapted for cysts may be used. Alternatively, the common gonyaulacoid or peridiniod patterns (Norris, 1978a) are indicated "gon" or "per" respectively. "Sus" refers to suessioid tabulation (Norris, 1978a), most clearly and complexly developed in Suessia Morbey in which plate number is high and variable, the diagnostic character being an anterior intercalary series with at least three, usually fastigiate plates (i.e. posterior margins angular relative to cingulum). The earliest suessioid genera are characterized by a disintegration archeopyle, whereas advanced types developed intercalary archeopyles (Dörhöfer and Davies, 1979).

The following logograms of some well-known genera help to clarify this system. Further examples may be found in Norris $(1978 \mathrm{a}, \mathrm{b})$. The logograms contain information on up to six variables, each category being separated by a semicolon.

Alterbia Vozzh. enend. Lentin and Williams

Pc; ap, aa; 1; sut-non-abs; pcin; per.

Gomualucista Deflandre ex Norris and Sarjeant emend

Sarjeant

Pc-Pa: ap; P; sut; gon.

Weraeliella Eisenack emend. Lentin and Williams

Pc; ap, 2aa, 2cn; 1; non-pen; per.

Hystrichosphaeridium Deflandre emend. Davey and Williams

Ch; A; int-1; gon.

Spiniferites Mantell emend. Sarjeant

Sp; P: sut; gon.

\section{Classification}

The revised classification of Norris (1978a, b), with emendations and additions by Dörhöfer and Davies (1979), is used to arrange illustrated genera in family groupings. This revised classification had its origins in the fundamental revision of existing fossil dinoflagellate families by Sarjeant and Downie (1974) and the principles proposed by them for adoption in the formulation of taxonomic units for dinoflagellates (Sarjeant and Downie, 1974: 13), viz. all stages of the life cycle should be used whenever possible in formulating and diagnosing taxa, both fossil and recent; a single epithet only is acceptable for identical fossil and living cysts, priority of publication determining the correct name; and the prime importance of salient morphologic features of fossil cysts in determining relationships and lineages.

Prior to Sarjeant and Downie's revision, no satisfactory supragencric scheme was available. Many of the families recognized by Sarjeant and Downie were internally coherent but proved difficult to relate at higher taxonomic levels. Norris $(1978 \mathrm{a}, \mathrm{b})$ examined these families in the light of improved understanding of tabulation patterns and archeopyle types. Of crucial importance to Norris's revision was the recognition of primitive but relatively complex tabulation in Triassic-Lower Jurassic dinoflagellates and the discrimination of earlier-evolved fastigiate intercalary plates from the later-evolved linteloid intercalary plates, any or all of the former contributing to archeopyle formation.

These observations led to recognition of the Rhaetogonyaulacineae, a suborder embracing the earliest and most primitive undoubted peridinialeans in the Triassic and later Mesozoic. Although we do not reject the notion of distantly related dinoflagellate forerunners in the Palaeozoic (see Sarjeant, 1974: 98-103 for a discussion and leading references), neither can we accept unequivocally the supposed dinophycean characters of putative Lower Palaeozoic dinoflagellates. They remain for us 
clearly defined acritarchs of doubtful affinity, with the exception of Arpylorus Calandra which appears to have some dinoflagellate-like features, but which are inadequate for familial placement.

The remaining three dinophycean suborders proliferated and eventually eclipsed the Rhaetogonyaulacineae in absolute taxonomic diversity in the late Mesozoic, although locally and regionally certain rhaetogonyaulacinean species continued to thrive or even dominate the phytoplankton (Dörhöfer and Davies, 1979; Dörhöfer, in press).

Examination of critical Jurassic and Cretaceous dinoflagellate assemblages allowed Dörhöfer and Davies (1979) to revise some aspects of Norris's classification. This included a fundamental reinterpretation and reassessment of certain rhaetogonyaulacinean genera, and the recognition of pseudoceratacean genera (included by Norris in the hystrichosphaeridiinean families Pseudoceratiaceae, Muderongiaceae, and Odontochitinaceae) as advanced and highly modified rhaetogonyaulacineans, the closest affinities being with the pareodiniaceans. The Muderongiaceae and Odontochitinaceae thereby are redundant.

Some of the deflandreinean families used here may require emendation on the basis of more detailed knowledge of tabulation, pericoel development, and archeopyle formation. Meanwhile, they are maintained pending further study.

The classification listed below incorporates these various changes and indicates by means of logograms the salient characters of each family, followed by references to illustrations in the Guide.

\section{Division Pyrrhophyta Pascher, 1914 Class Dinophyceae Fritsch, 1929 Order Peridiniales Haeckel, 1894}

A. Suborder Rhaetogonyaulacineae Norris, 1978b

1. Family Rhaetogonyaulacaceae Norris emend. Dörhöfer and Davies, 1979.

Pc-Pa; \pm ap, \pm aa; DIS; sut; sus. (Figs. 1-14).

2. Family Phallocystaceae Dörhöfer and Davies, 1979 Pc-Pa; \pm ap, \pm aa; 1 ; abs-sut-int; sus (-5a). (Figs. 15-18).

3. Family Pareodiniaceae Gocht emend. Dörhöfer and Davies, 1979

Pc-Pa; \pm ap, \pm aa; I; abs-sut; sus-gon (1-3a). (Figs. 19-26).

4. Family Pseudoceratiaceae Eisenack emend. Dörhöfer and Davies, 1979.

Pc-Pa; ap, 1-2aa, 1-2pc; Al; non-abs-pen; sus-gon. (Figs. 27-38).

B. Suborder Gonvaulaclestinca' Norris, $1978 \mathrm{~b}$

5. Family Gonyaulacystaceae Sarjeant and Downie emend. Sarjeant and Downie, 1966.

$\mathrm{Pa}$; \pm ap; P; sut; gon. (Figs. 39-54).

6. Family Apteodiniaceae Eisenack emend. Sarjeant and Downie, 1974.

$\mathrm{Pa} ; \pm$ ap, \pm aa; $\mathrm{P}$; abs-non; \pm pcin. (Figs. 55-67).

7. Family Spiniferitaceae Sarjeant and Downie emend. Sarjeant and Downie emend. Norris, 1978b.

Sp; 土 ap; P; sut; gon. (Figs. 68-77).

8. Family Endoscriniaceae Vozzhennikova emend. Sarjeant and Downie, 1974.

Pc; \pm ap, \pm aa; P; sut-abs; pcin; gon. (Figs. 78-92).

9. Family Scriniocassiaceae Sarjeant and Downie emend. Sarjeant and Downie, 1974.

Pc; \pm ap; P; non; pcel. (Figs. 93-99).

10. Family Cordosphaeridiaceae Sarjeant and Downie emend. Norris, 1978b.

$\mathrm{Ch}$; $\mathrm{P}$; int $(-1$ or $-n)-p e n ; \pm t r a b$; gon. (Figs. 100-113).

11. Family Lingulodiniaceae Sarjeant and Downie, 1974.

Ch; 士 ap; 1-5P; non. (Figs. 114-120).

12. Family Ctenidodiniaceae Sarjeant and Downie emend. Norris, $1978 \mathrm{~b}$.

Pa; \pm ap; (AP); sut-non; gon. (Figs. 121-129).

C. Suborder Histrichosphaeridiineale Norris, 1978b

13. Family Hystrichosphaeridiaceae Evitt emend. Sarjeant and Downie emend. Norris, $1978 \mathrm{~b}$. Ch; \pm aa; A; int-pen; \pm trab; gon. (Figs. 130-152).

14. Family Cleistosphaeridiaceae Sarjeant and Downie, 1974.

Ch; A; non. (Figs. 153-158).

15. Family Florentiniaceae Harker and Sarjeant emend. Norris, $1978 b$.

Ch; $\pm \mathrm{aa} ; \mathrm{A}+\mathrm{P}$; int $(-1$ or $-n)$; gon. (Figs. 159-163).

16. Family Areoligeraceae Evitt emend. Sarjeant and Downie, 1966.

Ma; A; non-pen: \pm trab. (Figs. 164-166).

17. Family Lithodiniaceae Norris, $1978 \mathrm{~b}$.

$\mathrm{Pa}$; \pm ap; A; sut-pen; gon. (Figs. 167-181).

18. Family Batiacasphaeraceae Dörhöfer and Davies, 1979.

$\mathrm{Pa}$; $\pm \mathrm{ap}$, $\pm \mathrm{aa}$; A; non; pcin. (Figs. 182-187).

19. Family Xiphophoridiaceae Sarjeant and Downie, 1966.

Sp; A; sut. (Figs. 188-190).

20. Family Senoniasphaeraceae Norris, 1978 b.

Pc; \pm ap, \pm aa; A; sut-abs; \pm pcin. (Figs. 191-199).

21. Family Membranilarnaciaceae Eisenack emend.

Sarjeant and Downie, 1966.

Pc; \pm ap; A; non; pcel. (Figs. 200-204).

22. Family Stephanelytraceac Stover, Sarjeant and Drugg, 1977.

Ap; A; sut-pen-non: coro. (Fig. 205). 
D. Suborder Deflandreineale Eisenack emend. Norris, $1978 \mathrm{~b}$

23. Family Deflandreaceate Eisenack emend. Sarjeant and Downie, 1974.

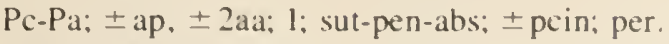

(Figs. 206-225).

24. Family Palaeoperidiniaceae Vozzhennikova emend. Sarjeant, 1967.

Pc-Pa: \pm ap, \pm aa; AlP; sut-pen-non-abs; per. (Figs. 226-234).

25. Family Wetzeliellaceae Vozzhennikova, 1961 Pc; ap, 2aa, 2cn; 1; non-pen; per. (Figs. 235-240).

26. Family Phthanoperidiniaceae Drugg and Loeblich, 1967.

Pa; ap. \pm aa; I; sut-non-abs; per. (Figs. 241-255).

27. Family Ovoidiniaceae Norris, $1978 \mathrm{~b}$

Pc: \pm ap, \pm aa; (AI): non-pcin; per. (Figs. 256 258).

\section{E. Suborders Incertue}

28. Family Ceratocoryaceae Stein, 1883.

Subfamily Thalassiphoroideae Gocht emend.

Sarjeant and Downie stat. nov. Norris, $1978 \mathrm{~b}$.

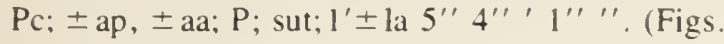
259-261).

29. Family Pyrophacaceae Lindemann emend. Steidinger and Davis, 1967.

Pc: 4HA; int; pcel. (Fig. 262).

30. Family Heteraulacacystaceae Drugg and Loeblich, 1967.

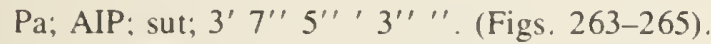

31. Family Microdiniaceae Eisenack emend. Sarjeant and Downie emend. McLean, 1973a.

$\mathrm{Pa}$; A; sut; 7" 6" ' Ip 1" "'. (Figs. 266-267).

\section{Order Dinophysidales Stein, 1883}

32. Family Nannoceratopsaceae Gocht, $1970 \mathrm{~b}$. $\mathrm{Pa}$; ap, aa; epitractal archeopyle; non-abs. (Fig. 268).

\section{Order Gymnodiniales Schütt, 1896}

33. Family Dinogymniaceae Sarjeant and Downie, 1974.

Pa; ap, aa; A; non; pcin. (Fig. 269).

Incertae Familiae (Figs. 270-276)

\section{Nomenclature}

In general, the recent index to genera and species of Lentin and Williams (1977b) has been used as a valid nomenclatural base with the following exceptions:

(a) Only genera with at least the minimum characters necessary for classification into fantilics are illustrated. A few doubtfully affiliated genera, however, are also included in "Incertae Familiae".

(b) Some genera recognized by us as synonymous are illustrated only by the senior synonym vis. AlterbiaSenegalinium; Pentadinium-Planinosphaeridium; Thalassiphora-Erikania.

(c) Those genera indicated as synonymous or superfluous by Lentin and Williams (1977b) but which we consider may be distinct, are illustrated individually pending further study viz. Dracodimium; Heliodinium; Imbatodinium; Komewuia; Palmnickia: Pluriarvalium; Soaniella; Trioperculodinium.

(d) Genera based only on the thecate stage are omitted.

(e) Only genera with resistant organic-walled cysts are included, i.e. those with mineralized cyst walls are omitted.

\section{How to Use the Guide}

This Guide will, we hope, be helpful in assigning species to their appropriate generic and higher taxonomic groups. The following procedure may be used for this purpose.

(i) Analyse the salient morphologic features of the unassigned species using a logogram to summarize selected features.

(ii) If all elements of the logogram have been identified, this should allow placement in a suborder and family.

(iii) Examine illustrations of the genera included in the family and select the most closely comparable genus or genera.

(iv) Refer to the Eisenack catalogue or similar species compendia, for illustrations and descriptions of species assigned to the suspected genus or genera, and thence to the primary literature for further information. Because the Eisenack catalogue generally lists basionyms, it may be necessary to peruse Lentin and Williams (1977b, 1978, and earlier compilations) to ascertain the original generic assignment of some species before they can be located in the Eisenack catalogue.

Rapid location of a particular genus may be made by reference to the alphabetical list of genera below. 


\section{Alphabetical Check List of Families and Genera}

The following list refers to families and genera selected for illustration in the Guide. The plates are arranged in taxonomic order; hence the plate explanations can be used as a taxonomic check list.

Acrunthoulax Sarjeant, 1968

Achilleodinium Eaton, 1976

Achomosphaera Evitt, 1963

Acrinorheca Cookson and Eisenack, 1960a

Adnurosphaeridium Williams and Downie, 1966b

Aireiana Cookson and Eisenack, 1965a

Alterbia Lentin and Williams, 1976

Amphidicadema Lentin and Williams, 1976

Amphorosphaeridium Davey, $1969 \mathrm{~b}$

Amphorula Dodekova, 1969

Andalusiella Riegel, 1974

Anshosphaeridium Cookson and Eisenack, 1968

Apectodinium Costa and Downie, 1976 stat. nov.

Lentin and Williams, 1977b

Aprobolocysta Duxbury, 1977

Aptea Eisenack, emend. Davey and Verdier, 1974

Apteodiniaceae Eisenack, emend. Sarjeant and

Downie, 1974

Apreodinium Eisenack, 1958

Aquadulcum Harland and Sarjeant, 1970

Arameosphaera Eaton, 1976

Archeorectalum Habib, 1972

Areoligera Lejeune-Carpentier, emend. Williams and Downie, 1966b

Areoligeraceae Evitt, emend. Sarjeant and

Downie, 1966

Areosphaeridium Eaton, 1971

Ascodinium Cookson and Eisenack, 1960a

Ascostomocistis Drugg and Loeblich, 1967

Athigmatocysta Duxbury, 1977

Avellodinium Duxbury, 1977

Bacchidinium Davey, in press

Balcarria Cookson and Eisenack, 1974

Batiacasphaera Drugg, 1970

Batiacasphaeraceae Dörhöfer and Davies, 1979

Belodinium Cookson and Eisenack, emend.

Dodekova, 1975

Biorlifera Habib, 1972

Bourkidinium Morgan, 1975

Breedoxella Norris, 1978b

Broomea Cookson and Eisenack, emend. Lentin and Williams, 1976

Bulbodinium Wetzel, 1960

Caligodinium Drugg, 1970

Callaiosphaeridium Davey and Williams, 1966

Canningta Cookson and Eisenack, 1960b

Camninginopsis Cookson and Eisenack, 1962b

Comnosphaeropsis Wetzel, emend. Williams and Downie, 1966 b

Canmulodinium Alberti, 1961

Carpestella Grigorovitch, 1969

Carpodinum Cookson and Eisenack, emend

leftingwell and Morgan, 1977
Fig. No.

39

100

68

78

130

101

206

207

102

131

241

270

235

27

28

$55-67$

55

226

103

56

164

$164-166$

132

256

271

79

69

Danea Morgenroth, 1968

Dapcodinium Evitt, 1961a

Deflandrea Eisenack, emend. Lentin and Williams 1976

104

257

182

$182-187$

167

121

133

122

19

208

20

159

29

168

70

21

40

41 emend. Pocock, 1972

Cladopvidium McLean, 1972

Clathroctenocystis Wiggins, 1972

Cleistosphaeridiaceae Sarjeant and Downie, 1974

Cleistosphaeridium Davey, Downie, Sarjeant and Williams, 1966

Cobricosphaeridium Harland and Sarjeant, 1970

Codoniella Cookson and Eisenack, 1961a

Comesodinium Deflandre and Courteville, 1939

Comparodinium Morbey, 1975

Composirosphaeridium Dodekova, 1974

Conosphaeridium Cookson and Eisenack, 1969

Cordosphaeridiaceae Sarjeant and Downie, 1974 emend. Norris, 1978b

Cordosphaeridium Eisenack, emend. Davey, 1969b

Coronifera Cookson and Eisenack, emend. Davey, 1974

Cribroperidinium Neale and Sarjeant, emend.

Davey, 1969a

Ctenidodiniaceae Sarjeant and Downie, 1966 emend. Norris, 1978b

Ctenidodinium Deflandre, emend. Sarjeant, 1975a

Cyclapophysis Benson, 1976

Ciclodiction Cookson and Eisenack, 1958

Ciclonephelium Deflandre and Cookson, emend Ioannides et al., 1977

Deflandreaceae Eisenack, emend. Sarjeant and Downie, 1974

Diacanthum Habib, 1972

Dichadogonvaulax Sarjeant, emend. Sarjeant, 1975 a

Diconodinium Eisenack and Cookson, 1960

Dimidiadinium Brideaux, 1977

Dingodinium Cookson and Eisenack, 1958

Dinogymniaceac Sarjeant and Downie, 1974

Dinogymnium Evitt, Clarke and Verdier, 1967

Dinopterygium Deflandre, 1935

Dioxyd Cookson and Eisenack, 1958

Diphyes Cookson, emend. Davey and Williams, 1966

Discorsia Duxbury, 1977 1973

Distatodinium Eaton, 1976

Dodekovia Dörhöfer and Davies, 1979

Dorocysta Davey, 1970

Dracodinium Gocht, 1955

Druggidium Habib, 1973

Duosphaeridium Davey and Williams, 1966
Cassiculosphaeridia Davey, 1969a

183

Carillopsis Drugg, 1970

184

Cauca Davey and Verdier, 1971

93

Ceratiopsis Vozzhennikova, 1963

Ceratocoryaceae Stein, 1883

Chatangiella Vozzhennikova, emend. Lentin and

Willians, 1976

Chiropteridium Gocht, 1960

Chlamvilophorella Cookson and Eisenack, 1958

Chytroeisphaeridia (Sarjeant) Downie Evitt, and Sarjeant,

$259-26$

210

165

200

Cryptarchaeodinium Deflandre, emend. Gitmez, 1970

$153-158$

153

154

80

272

15

134

105

100-113

106

114

42

21-129

124

107

94

166

108

1

206-225

Disphaeria Cookson and Eisenack, emend. Norvick.

16

188
236 
Egmonsodinium Gitmez and Sarjeanı, 1972

Eisenackia Deflandre and Corokson. emend. McLean. 1973 a

Ellipsodinium Clarke and Verdier, 1967

Ellipsoidicturum Klemenı, 1960

Emmetrocista Stover, 1975

Endoceratium Vozzhennikova, 1965

Endoscriniaceac Vozzhennikova, emend. Sarjeant and Downie, 1974

Endoscrinium (Klement) Vozzhennikova, 1967

Energlinia Sarjeant. 1976

Eocludopvis Morgenroth, 1966

Eodimic Eisenack, emend. Gocht, 1975a

Epelidosphoseridia Davey, 1969a

Epiplosphaera Klement, 1960

Exochosphaeridium Davey, Downie, Sarjeant and Williams, 1966

Fibradinium Morgenroth, 1968

Florentimia Davey and Verdier, 1973

Florentiniaceae Harker and Sarjeant, entend. Norris, $1978 b$

Fromea Cookson and Eisenack, 1958

Fusiformacisła Morgan. 1975

Gardodimium Alberti, 1961

Geiselodinium Krutzsch, 1962

Gillinia Cookson and Eisenack, 1960a

Ginginodinium Cookson and Eisenack, emend Lentin and Williams, 1976

Glabridinium Brideaux, 1977

Glomodinium Dodekova, 1975

Glossodinium loannides, Stavrinos and Downie, 1977

Glyphanodinium Drugg, 1964

Gochteodinia (Vozzhennikova) Norris, 1978b (not illustrated, see Family Pareodiniaceae)

Gonvaulacysia Deflandre, ex Norris and Sarjeant, emend. Sarjeant, 1969

Gonyaulacystaceae Sarjeant and Downie, emend.

Sarjeant and Downie, 1974

Hapsidaulax Sarjeant, 1975b

Hapsocista Davey, in press

Hebecisia Bujak and Fisher, 1976

Heibergella Bujak and Fisher, 1976

Heliodinium Alberti, 1961 emend. Sarjeant, 1966

Hemicystodinium Wall, 1967

Hemiplacophora Cookson and Eisenack, 1965a

Herendeenia Wiggins, 1969

Heslertonia Sarjeant, 1966

Heteraulacacista Drugg and Loeblich, 1967

Heteraulacacystaceae Drugg and Loeblich, 1967

Heterosphaeridium Cookson and Eisenack, 1968

Hexagonifera Cookson and Eisenack, emend.

Cookson and Eisenack, 1962b

Histiocvsia Davey, 1969a

Histiophora Klement, 1960

Homornblium Davey and Williams, 1966

Horologinella Cookson and Eisenack, 1962a

Hystrichodinium Deflandre, emend. Clarke and

Verdier, 1967

Hystrichogoniaulax Sarjeant, 1969

Histrichokolpoma Klumpp, emend. Williams and

Downie, 1966a

Hystrichosphaeridiaceae Eviu, emend Vorris, 1978h $130-152$

Histrichosphaeridium Deflandre, emend. Davey

and Williams, 1966
170

58

171

138

30

$78-92$

82

126

160

127

185

139

115

172

161

159-163

273

59

201

227

173

228

83

22

84

174

Hismihesphacropsis Dellindre, emend. Gocht. 1976

Imbatodimum Vozzhennikova, 1967

Impletosphaeridium Morgenroth, 1966

Incernae familias

Inersidimum McLean, 1973b

Isubelidimiom Lentin and Williams, 1977a

Kallosphaeridium De Coninck, 1969

Kenlevia Cookson and Eisenack, 1965b

Kisselovia Vozzhennikova, 1963

Kleishriasphaeridium Davey, 1974

Komewruid Cookson and Eisenack, 1960b

Laciniadinium Mclntyre, 1975

Lanterna Dodekova, 1969

Lamternosphaeridium Morgenroth, 1966

Leipokatium Bradford, 1975

Lejeumecysta Artzner and Dörhöfer, 1978

Leptodinium Klement, emend. Sarjeant, 1969

Lingulasphaera Drugg, 1970

Lingulodiniaceae Sarjeant and Downie, 1974

Lingulodinium Wall, emend. Wall, Dale and Harada, 1973

Lirhodinia Eisenack, emend. Gocht, 1975b

Lithodiniaceae Norris, 1978b

Lisosphaeridium Davey and Williams, emend

Davey and Verdier, 1973

Luehndea Morgenroth, 1970

Lunaradinium Brideaux and McIntyre, 1973

Luxadinium Brideaux and Mclntyre, 1975

Maduradinium Cookson and Eisenack, 1970

Membranilarnacia Eisenack, emend. Williams and Downie, 1966b

Membranilarnaciaceae Eisenack, emend. Sarjeant and Downie, 1966

Membranosphaera Samoilovitch ex Norris and Sarjeant, emend. Drugg, 1967

Mendicodinium Morgenroth, 1970

Microdiniaceae Eisenack, emend. McLean, 1973a

Microdinium Cookson and Eisenack, emend.

Sarjeant, 1966

Moesiodinium Antonescu, 1974

Montanarocista Corradini, 1973

Muderongia Cookson and Eisenack, 1958

Muiradimum Harland and Sarjeant, 1970

Muiriella Churchill and Sarjeant, emend.

Harland and Sarjeant. 1970

Multispimula Bradford. 1975

Muratodinium Drugg, 1970

116

179

$167-181$

143

$200-204$

Nannoceratopsis Deflandre, emend. Evitt, 196/b

Nannoceratopsaceae Gocht, 1970b

Nelchimepsis Wiggins, 1972

Nelsoniella Cookson and Eisenack, 1960a

Nematosphaeropsis Deflandre and Cookson, emend.

Williams and Downic, 1966

Nexosispinum Davey, in press

Noricysia Bujak and Fisher, 1976 
Omatla Cookson and Eisenack, emend. Wiggins, 1969

Operculodinium Wall, 1967

Ovolıniaceae Norris, 1978 b

Ovordmum Davey, emend. Lentin and Willians, 1976

Palcaeocistodinium Alberti, 1961

Palcieolisstrichoplora Deflandre, emend. Deflandre and Cookson, 1955

Palaeoperidiniaceae Vozzhennikova, emend. Sarjeant. 1967

Palcoeperidinium Deflandre, emend. Sarjeant, 1967

Polmnickia Eisenack, 1954

Palvodinimm Gocht, 1970a

Paragomialacista Johnson and Hills, 1973

Parilecaniclla Cookson and Eisenack, emend. Elsik, 1977

Pareodinic Deflandre, emend. Wiggins, 1975

Pareodiniaceae Gocht, emend. Norris, 1978b

Parvocavalus Gitmez, 1970

Parsulodinium Dodekova, 1975

Pentadinium Gerlach, 1961

Peridictvocista Cookson and Eisenack, 1974

Perisseiasplacridium Davey and Williams, 1966

Phallocista Dörhöfer and Davies, 1979

Phallocystaceae Dörhöfer and Davies, 1979

Phanerodinium Deflandre, 1937

Phoberocista Millioud, 1969

Phthanoperidiniaceae Drugg and Loeblich, 1967

Phthanoperidinium Drugg and Loeblich, 1967

Pluriarvalium Sarjeant, 1962

Polygonifera Habib, 1972

Polvsphaeridium Davey and Williams, 1966

Polvstephanephorus Sarjeant, 1961b

Prionodinium Leffingwell and Morgan, 1977

Prolixosphaeridium Davey, Downie, Sarjeant and Williams, 1966

Protoellipsodinium Davey and Verdier, 1971

Psaligonvanlax Sarjeant, 1966

Pseudoceratiaceae Eisenack, emend. Norris,

$$
1978 \mathrm{~b}
$$

Psendoceratium Gocht, 1957

Psendodeflandrea Alberti, 1959

Pterodinium Eisenack, 1958

Pyrophacaceae Lindemann, emend. Steidinger and Davis, 1967

Pyxidiella Cookson and Eisenack, 1958

Pixidinopsis Habib, 1976

Raphridodinium Deflandre, 1936

Renidinium Morgenroth, 1968

Rhaetogonyaulacaceac Norris, emend. Dörhöfer and Davis, 1979

Rhaetogonvaulax Sarjeant, emend. Harland,

Morbey and Sarjeant. 1975

Rhombodella Cookson and Eisenack, 1962b

Rlumbodinium Gocht, 1955

Rlunchodiniopsis Deflandre, 1935

Romunodinium Baltes, 1971

Rotmestia Cookson and Eisenack, 196lb

Sacpodminm Harris, 1974

Samlandia lisenack, 1954

Schemulophore Deflandre and Cookson, 1955

Scroniocassaceace Sarjeant and Downie, emend Sarjeant and Downic, 1974
Scrimiocassis Gocht, 1964

98
96

118

$256-258$

217

218

226-234

231

111

193

25

275

26

19-26

194

180

259

145

146

17

15-18

276

36

241-255

249

10

195

158

147

52

148

119

87

27-38

37

219

53

262

250

62

189

203

1-14

9

187

238

54

260

88

232
Scriniodinium Klement, 1957

Selenopempluix Benedek, 1972

251

Senomiasphacera Clarke and Verdier. 1967

196

Senoniasphaeraceae Norris, 1978b

$190-199$

Silicisplaera Davey and Verdier, 1976

112

Sirmiodinium Alberti. emend. Warren, 1973

197

Simolenskiella Vozzhennikova, 1967

220

Soamiella Vozzhennikova, 1967

252

Speetonia Duxbury, 1977

63

Spinidinium Cookson and Eisenack, emend. Lentin and Williams, 1976

Spiniferitaceae Sarjeant and Downie, emend.

Norris, 1978b

Spiniferites Mantell, emend. Sarjeant, 1970

Spongodinium Deflandre, 1936

Stelladinium Bradford, 1975

Stephanelytraceae Stover, Sarjeant and Drugg. 1977

Stephanelviron Sarjeant, 1961 a

Steplodinium Deflandre, emend. Davey, 1970

Subrilidinium Morgenroth, 1968

Subtilisplucera Jain and Millepied, emend.

Lentin and Williams, 1976

Suessia Morbey, 1975

Sumatradinium Lentin and Williams, 1976

Surculosphaeridium Davey, Downie, Sarjeant and Williams, 1966

Susadininm Dörhöfer and Davies, 1979

Sialbardella Manum, 1960

Sverdrupiella Bujak and Fisher, 1976

Sustematophora Klement, 1960

$68-77$

77

99

253

205

205

90

11

233

12

254

149

18

222

13

150

Taeniophora Klement, 1960

Tanyosphaeridium Davey and Williams, 1966

151

Tapeinosphacridium loannides, Stavrinos and Downie, 1977

Tectatodinium Wall, 1967

Teneridinium Krutzsch, 1962

Thalassipliora Eisenack and Gocht, emend.

Gocht, 1968

Toolongia Cookson and Eisenack, 1960a

Triblastula Wetzel, emend. Morgenroth, 1966

Trichodinium Eisenack and Cookson, emend.

Clarke and Verdier, 1967

Trigonopxidia Cookson and Eisenack, 1961a

Trioperculodinium Drugg, 1970

Trithrodinium Drugg, emend. Lentin and

Williams, 1976

Tuberculodinium Wall, 1967

Tubidermodinium Morgenroth, 1966

Tuboruberella Vozzhennikova, 1967

Turbiosplacera Archangelsky, 1969

64

65

234

261

128

91

66

198

120

223

262

265

92

113

Uvalodinium Vozzhennikova, 1963

224

Valensiella Eisenack, 1963

204

14

Vos-hennikovia Lentin and Williams, 1976

255

Wallodinium Loeblich and Loeblich, 1968

199

Wanaca Cookson and Eisenack, 1958

129

Wetzeliella Eisenack, emend. Lentin and

Willians, 1976

239

Wetzeliellaceae Vozzhennikova, 1961

Wilsonidium Lentin and Williams, 1976

235-240

240

Xenascus Cookson and Eisenack, 1969

38

Xenicodinium Klement, 1960

67 
Cenikenen Cookson and Eisenack, 1960a

Xiphophoridiaceac Sarjeant and Downie, 1966

fiphophoridium Sarjeant. 1966

The recently published volume of systematic analyses of fossil dinoflagellates by Stover and Evitt (1978) is a valuable source of information on circumscriptions and limits of organic-walled genera, and effectively supplements the illustrations in this guide. They have erected the following new genera not included in this guide: Aldorfia. Alisocrsta. Balteoctia, Boreocvsta, Corrudinimm. Earonicusta, Elvrocista, Eucladinium, Eurdinium, Fibrocista. Glaphrocista, Impagidinium, K'iokansium, Leberidocista, Villioudodinium. Phelodinium, and Ponriadinium.

By reference to new taxa "in press" it is not our intention to thereby validly publish these names. (See Article 34. International Code of Botanical Nomenclature.)

\section{Acknowledgements}

This work was made possible by operating grants from the National Research Council of Canada and research agreenents from Energy, Mines and Resources Canada (G. Norris, principal investigator); an NRC Negotiated Development Grant postdoctoral fellowship and research associateship to G. Dörhöfer; a University of Toronto Open Scholarship and an Ontario Graduate Scholarship to S. Poplawski; and NRC and EMR research assistantships to D. Artzner, E.H. Davies, and A. Fasola. We are particularly indebted to the following for providing information and critical comments on certain fossil dinoflagellates: W.R. Evitt, J. Bujak, R. Davey, G.L. Williams. Two anonymous reviewers provided constructive critical comments which helped to improve the Guide. Our thanks go to Elliott Burden for his work during the initial stages of this project and to Anne Naldrett for artistic assistance. We alone are responsible for the final generic concepts and illustrations as interpreted here.

Several diagrams have been reproduced with permission of the publishers from Eisenack's Katalog der fossilen Dinoflagellaten. Hystrichospharen und verwandien Mikrofossilien, from the Review of Palaeobotany and Palynology (Elsevier, Amsterdam) and from the Bulletin of the British Museum (Natural History). We acknowledge with gratitude the cooperation of these publishers and the authors who provided illustrations. 


\section{Literalure Cited}

ALBERTI. G

1959 Über Pseudodeflandrea n. gen. (Dinoflag.) aus dem Mittel-Oligozän von Norddeutschland. Hamburg Geologisches Staatsinstitut, Mitteilungen 28:91-92.

1961 Zur Kenntnis mesozoischer und alttertiärer Dinoflagellaten und Hystrichosphaerideen von Nord-und Mitteldeutschland sowie ennigen anderen Europäischen Gebieten. Palaeontographica (Abt. A) 116:1-58.

A.NTONESCU, E

1974 Un nouveau genre de dinoflagellé dans le Jurassique moyen de Roumanie. Revue de Micropaléontologie 17:61-65.

ARCHANGELSKY, S

1969 Sobre el paleomicroplancton del Terciario inferior de Rio Turbio, Provincia de Santa Cruz. Ameghiniana 5:406416.

\section{ARTZNER, D.G. and G. DORHOFER}

1978 Taxonomic note: Lejeunecysta nom.nov.pro. Lejeunia Gerlach 1961 emend. Lentin and Williams, 1976 - dinoflagellate cyst genus. Canadian Journal of Botany 56:13811382.

BALTES, N

1971 Pliocene Dinoflagellata and Acritarcha in Romania. In Farinacci, A., ed., Proceedings of the Second Planktonic Conference, Rome, 1970, vol. 1, pp. 1-19.

BENEDEK, P.N

1972 Phytoplanktonten aus dem Mittel- und Oberoligozän von Tönisberg (Niederrheingebiet). Palaeontographica (Abt. B) $137: 1-71$.

BENSON. D G

1976 Dinoflagellate taxonomy and biostratigraphy at the Cretaceous-Tertiary boundary, Round Bay, Maryland. Tulane Studies in Geology and Paleontology 12:169-233.

BRADFORD, M R

1975 New dinoflagellate cyst genera from the recent sediments of the Persian Gulf. Canadian Joumal of Botany 53:30643074.

BRIDEALX. W W

1977 Taxonomy of Upper Jurassic-Lower Cretaceous microplankton from the Richardson Mountains, District of Mackenzie, Canada. Geological Survey of Canada, Bulletin $281: 1-89$

BRIDEALX, W W and D J. MAINTYRE:

1973 L.unatadinium dissolutum gen. et sp. nov., a dinoflagellate cyst from Lower Cretaceous rocks, Yukon Territory and northern District of Mackenzie. Bulletin of Canadian Petroleun Geology 21:395-402.

1975 Mıospores and microplankton from Aptian-Albian rocks along Horton River, District of Mackenzic. Geological Survey of Canada, Bulletin 252:1-85.

BUSAK, J.P and M J FSHII $R$

1976 Dinoflagellate cysts from the Upper Triassic of arctic Canada Micropaleontology 22:44-70.
CHURCHILL, D.M and W A.S SARJEANT

1963 Freshwater microplankton from Flandrian (Holocene) peats of south-western Australia. Grana Palynologica 3:29-53.

CLARKE, RF $A$ and $J$.P VERDIER

1967 An investigation of microplankton assemblages from the Chalk of the Isle of Wight, England. Koninkluke Nederlandse Akademie van Wetenschappen. Afdeling Natuurkunde, Verhandelingen, Series 1, 24(3): 1-96.

COOKSON. $1 . \mathrm{C}$

1965 Cretaceous and Tertiary microplankton from southeastern Australia. Proceedings of the Royal Society of Victoria $78: 85-93$.

COOKSON, $1 \mathrm{C}$ and A EISENACK

1958 Microplankton from Australian and New Guinea Upper Mesozoic sediments. Proceedings of the Royal Society of Victoria 70:19-79.

1960a Microplankton from Australian Cretaceous sediments. Micropaleontology 6:1-18.

1960b Upper Mesozoic microplankton from Australia and New Guinea. Palaeontology 2:243-261.

1961 a Upper Cretaceous microplankton from the Belfast No. 4 Bore, south-western Victoria. Proceedings of the Royal Society of Victoria 74:69-76.

$1961 \mathrm{~b}$ Tertiary microplankton from the Rottnest Island Bore, Western Australia. Journal of the Royal Society of Western Australia 44:39-47.

1962a Some Cretaceous and Tertiary microfossils from Western Australia. Proceedings of the Royal Society of Victoria 75:269-273.

1962b Additional microplankton from Australian Cretaceous sediments. Micropaleontology 8:485-507.

1965a Microplankton from the Browns Creek Clays, southwestern Victoria. Proceedings of the Royal Society of Victoria 79:119-131.

1965 b Microplankton from the Dartmoor Formation, southwestern Victoria. Proceedings of the Royal Society of Victoria 79:133-137.

1968 Microplankton from two samples from Gingin Brook No. 4 Borehole, Western Australia. Joumal of the Royal Society of Western Australia 51:110-122.

1969 Some microplankton from two bores at Balcalta, Western Australia. Journal of the Royal Society of Western Australia 52:3-8.

1970 Cretaceous microplankton from the Eucla Basin, Western Australia. Proceedings of the Royal Society of Victoria 83:137-157

1974 Mikroplankton aus Australischen Mesozoischen und Tertiären Sedimenten. Palaeontographica (Abt. B) 148:4493.

CORRADINI, D

1973 Non-calcareous microplankton from the Upper Cretaceous of the Northern Apennines. Bollettino della Socictà Paleontologica Italiana 11:119-197.

$\operatorname{Cos} 1 \mathrm{~A}$, L.1. and C. DOWNIE

1976 The distribution of the dinoflagellate Wereliella in the Palaeogene of north-western Europe. Palaeontology $19: 591-614$

DAVEY, RI

1969a Non-calcareous microplankton from the Cenomanian of England, northern France and North America, Part l. Bulletin of the British Museum of Natural History (Geology) $17: 103-180$ 
1969b The evolution ol certain Upper Cretaceous hystrichospheres from South Africa. Paleontologia Africana 12:25-51.

1970 Non-calcaresus microplankton from the Cenomanian of England, northern France and North Americia, Part 11 Bulletin of the British Museun of Natural History (Geology) 18:333-397

1974 Dinoflagellate cysts Irom the Barremian of the Specton Clay, England. Birbal Sahni Institute of Palaeobotany. Special Publication 3:41-75.

In press Marine Aptian-Albian palynomorphs from sites $400 \mathrm{~A}$ and 402A IPOD Leg 48 Northern Bay of Biscay. Initial Report, Deep Sea Drilling Project.

DAVEY, R J., C DOWVIE, W A S SARJEANT and GL WILLIAMS

1966 Fossil dinoflagellate cysts attributed to Balrisphaeridium. Bulletin of the British Museum of Natural History (Geology). Supplement 3:157-175

1969 Generic reallocations. Bulletin of the British Museum of Natural History (Geology), Appendix to Supplement 3:1517.

D.AEY, R J and J -P. VERDIER

1971 An investigation of microplankton assemblages from the Albian of the Paris Basin. Koninklijke Nederlandse Akademie van Wetenschappen, Afdeling Natuurkunde, Verhandelingen. Series 1, 26(2):1-58.

1973 An investigation of microplankton assemblages from latest Albian (Vraconian) sediments. Revista Española de Micropaleontología 5:173-212

1974 Dinoflagellate cysts from the Aptian type sections at Gargas and La Bédoule, France. Palaeontology 17:623-653.

1976 A review of certain non-tabulate Cretaceous hystrichosphaerid dinocysts. Review of Palaeobotany and Palynology $22: 307-335$

DAVEY, R J and G L WTLLIAMS

1966 The genus Histrichosphaeridium and its allies. Bulletin of the British Museum of Natural History (Geology), Supplement 3:53-106.

Decontrick, J

1969 Dinophyceae et Acritarcha de l'Yprésien du Sondage de Kallo. Institut Royal des Sciences Naturelles de Belgique, Mémoire 161:1-67.

DEFLANDRE. G

1935 Considérations biologiques sur les microorganismes d'origine planctonique conservés dans les silex de la craie. Bulletin Biologique de la France et de la Belgique $69: 213-244$

1936 Microfossiles des silex crétacés. Première partie. Généralités, flagellés. Annales de Paléontologie 25:151191

1937 Phanerodinium, genre nouveau de dinoflagellé fossile des silex. Bulletin de la Société Française de Microscopie 6:109-115

1938 Microplancton des mers Jurassiques conservé dans les marnes de Villers-sur-Mer (Calvados); Etude liminaire et considérations générales. Travaux de la Station Zoologique de Wimereux 13:147-200

1939 Sur les dinoflagellés des schistes bitumineux d'Orbagnoux (Jura). Bulletin de la Société Française de Microscopıe $8: 141-145$

1947 Sur quelques microorganısmes planctonıques des silex Jurassiques. Bulletin de l'Institut Océanographique de Monaco $921: 1-10$.
DEILANDRE, G and I C COXKSOY

1955 Fossil microplankton from Australian Late Mesoroce and Tertiary sediments. Australian Journal of Marine and Freshwater Research 6:242-313

DEII.ANIDRI. G and H COURTIVILLL

1939 Note préliminaire sur les microlossiles des silex crétacés du Cambrésis. Bulletın de la Societé Française de Microscopie 8:95-106.

DEFLANDRE, G and $M$ DFIT.ANDRE RIGALD

1943-1974 Fichier Mıcropaléontologique général. Series 1, 3.

5-8, 10-16. Paris, Centre National de la Recherche Scientifique.

IXODEKOVA, L

1969 Dinollagellés et acritarches du Tithonique aux environs de Pleven, Bulgarie centrale du nord. Bulgarska Akademiya na Naukite, Geologicheski Institut, Izvestiya, Seriya Paleontologiya 18:13-24.

1974 Compositosphaeridium gen. n. - a new genus dinoflagellate cyst. Bulgarska Akademiya na Naukite, Geologicheski Institut, Izvestiya, Seriya Paleontologiya 23:25-30.

1975 New Upper Bathonian dinoflagellate cysts from northeastern Bulgaria. Paleontologiya, Stratigrafiya i Litologiya $2: 17-34$

DÖRHÖER, $\mathrm{C}$

In press Principles of dinoflagellate cyst provincialism: the Albian of the Northern Hemisphere. Marine Micropaleontology.

DÖRHÖFER. G. and E.H. DAYIES

1979 Evolution of archeopyle and tabulation in rhaetogonyaulacinean dinoflagellate cysts. Life Sciences Miscellaneous Publications. Toronto, Royal Ontario Museum.

DOWVIE, C and W.A.S. SARJEANT

1965 Bibliography and index of fossil dinoflagellates and acritarchs. Geological Society of America, Memoir 94:1180

1966 The morphology, terminology and classification of fossil dinoflagellate cysts. Bulletin of the British Museum of Natural History (Geology). Supplement 3:10-17

DRUGG, W.S

1964 Glyphanodinium, a new dinoflagellate genus from the Paleocene of California. Proceedings of the Biological Society of Washington 77:237-240.

1967 Palynology of the Upper Moreno Formation (Late Cretaceous-Paleocene) Escarpado Canyon, California. Palaeontographica (Abt. B) 120:1-71.

1970 Some new genera, species, and combinatuons of phytoplankton from the Lower Tertiary of the Gulf Coast, U.S.A. North American Paleontological Convention. Chicago, 1969. Proceedings G, pp. 809-843.

DRUGG. W'S and A R LOIBLICH, JR

1967 Some Eocene and Oligocene phytoplankton from the Gulf Coast, U.S.A. Tulane Studies in Geology 5. 181-194

DI YBLRY, S

1977 A palynostratigraphy of the Berriasian to Barremian of the Specion Clay of Speeron. England. Palaeontographica (Abt. B) $160: 17-67$

1971 A morphogenetic series of dinoflagellate cysts from the 
Bracklesham Beds of the 1sle of Wight, Hampshire, England In Fannacci, A., ed., Proceedings of the Second Planktonic Conference, Rome, 1970, vol. 1. pp. 355-379.

1976 Dinoflagellate cysts from the Bracklesham Beds (Eocene) of the 1sle of Wight. Southern England. Bulletin of the British Museum of Natural History (Geology) 26:227-332.

EISI:VACK. A

1935 Mikrofossilien aus Doggergeschieben Ostpreussens. Zeitschrift für Geschiebeforschung 11:167-184.

1936 Eodinia pachvthera n.g., n.sp., ein primitiver Dinoflagellat aus einem Kelloway-Geschiebe Ostpreussens. Zeitschrilt für Geschiebeforschung 12:72-75.

1938 Die Phosphoritknollen der Bernsteinformation als Überlieferer tertiären Planktons. Physikalisch-ökonomische Gesellschaft zu Königsberg i. Pr., Schriften 70:181-188.

1954 Mikrofossilien aus Phosphoriten des Samlandischen Unteroligozäns und über die Einheitlichkeit der Hystrichosphaerideen. Palaeontographica (Abt. A) 105:49-95.

1958 Mikroplankton aus dem norddeutschen Apt. Neues Jahrbuch für Geologie und Paläontologie, Abhandlungen $106: 383-422$

1961 Einige Erörterungen über fossile Dinoflagellaten nebst Übersicht über die zur Zeit bekannten Gattungen. Neues Jahrbuch für Geologie und Paläontologie, Abhandlungen 112:281-324

1963 Zur Membranilarnax-Frage. Neues Jahrbuch für Geologie und Paläontologie, Monatshefte 1963(2):98-103.

1964-1975 Katalog der fossilen Dinoflagellaten, Hystrichosphäeren und verwandten Mikrofossilien. Stuttgart, E. Schweizerbartsche Verlagsbuchhandlung. 2 vols.

EISENACK. A AND I C COOKSON

1960 Microplankton from Australian Lower Cretaceous sediments. Proceedings of the Royal Society of Victoria 72:1-11.

EISENACK. A and H GOCHT

1960 Neue Namen für einige Hystrichosphären der Bernsteinformation Ostpreussens. Neues Jahrbuch für Geologie und Paläontologie, Monatshefte 1960 (11):511-518.

ELSIK, W C

1977 Paralecaniella indentata (Deflandre and Cookson 1955) Cookson and Eisenack 1970 and allied dinocysts. Palynology 1:95-102.

EVITT, W R

1961 a Dapcodinium priscum n. gen., n.sp., a dinoflagellate from the Lower Lias of Denmark. Journal of Paleontology 35:996-1002.

$196 \mathrm{lb}$ The dinoflagellate Namnoceratopsis Deflandre: morphology, affinities and infraspecific variability. Micropaleontology $7: 305-316$.

1963 A discussion and proposals concerning fossil dinoflagel lates, hystrichospheres, and acritarchs, 1. Proceedings of the National Academy of Sciences (Washington) 49:158 164 .

1975 Introduction to the forum and remarks on classification and morphology. American Association of Stratigraphic Palynologists, Contribution Series 4:7-13.

FVIIT, W R, R I. A CLARKE and S -P VI.RDII:R

1967 Dinollagellate studies 111. Dinogumnium acuminamum n gen., n.sp. (Maastrichtian) and other fossils formerly referable to Gimmodinium Stein. Stanlord University Publications, Geological Sciences 10:1-27.
EVITT. W R , I K LENTIN, ME MILLIOUD, LE STOVER and G L WILLIAMS

1977 Dinoflagellate cyst terminology. Geological Survey of Canada, Paper 76-24:1-11

FRITSCH, F.E

1929 Evolutionary sequence and affinities among Protophyta Biological Reviews 4:103-151.

GERLACH, E.

1961 Mikrofossilien aus dem Oligozän and Miozän Nordwestdeutschlands, unter besonderer Berücksichtigung der Hystrichosphären und Dinoflagellaten. Neues Jahrbuch für Geologie und Paläontologie, Abhandlungen 112:143-228

GITMEZ, G.U

1970 Dinoflagellate cysts and acritarchs from the basal Kimmeridgian (Upper Jurassic) of England, Scotland and France. Bulletin of the British Museum of Natural History (Geology) 18:231-331.

GITMEZ, GU and W A S SARJEANT

1972 Dinoflagellate cysts and acritarchs from the Kimmeridgian (Upper Jurassic) of England, Scotland and France. Bulletin of the British Museum of Natural History (Geology) $21: 171-257$

GOCHT, H.

1955 Rhombodinium und Dracodinium zwei neue Dinoflagellaten-Gattungen aus dem norddeutschen Tertiär. Neues Jahrbuch für Geologie und Paläontologie. Monatshefte 1955(2):84-92.

1957 Mikroplankton aus dem nordwestdeutschen Neokom (Teil 1). Paläontologische Zeitschrift 31:163-185

1960 Die Gattung Chiropteridium n. gen. (Hystrichosphaeridea) im deutschen Oligozän. Paläontologische Zeitschrift 34:221-232.

1964 Planktonische Kleinformen aus dem Lias/DoggerGrenzbereich Nord- und Süddeutschlands. Neues Jahrbuch für Geologie und Paläontologie, Abhandlungen 119:113-133.

1968 Zur Morphologie und Ontogenie von Thalassiphora (Dinoflagellata). Palaeontographica (Abt. A) 129:149-156.

1970a Dinoflagellaten-Zysten aus einem Geschiebefeuerstein und ihr Erhaltungszustand. Neues Jahrbuch für Geologie und Paläontologie, Monatshefte, 1970(3):129-140.

$1970 \mathrm{~b}$ Dinoflagellaten-Zysten aus dem Bathonium des Erdölfeldes Aldorf (NW Deutschland). Palaeontographica (Abt. B) 129: 125-165.

1975a Neuuntersuchung von Eodinia pachvihoca Eisenack. 1936 (Dinoflagellata, Oberjura). Neues Jahrbuch für Geologie und Paläontologie, Abhandlungen 148:12-32.

1975b Morphologie und Wandstruktur von Lithodinia jurassica Eisenack 1935 (Dinoflagellata, Oberjura). Neues Jahrbuch für Geologie und Paläontologie, Monatshefte 1975(6):343-359.

1976 Hrstrichosphaeropsis quasicribrala (O. Wetzel), ein Dinoflagellat aus den Mastricht Nordeuropas. Neues Jahrbuch für Geologie und Paläontologie, Monatshefte $1976(6): 321-336$

GiRIGOROVICH. A S

1969 Die neue Gattung Carparella (Dinoflagellata) aus Ablagerungen des Dans bis Paleozäns der Karpaten. Paleontologicheskiy Sammelwerk (Sbornik) 2(6):74-76.

HAIIIB, D

1972 Dinoflagellate stratigraphy Leg 11, Deep Sea Drilling 
Project. Intial Reports of the Deep Sea Drilling Project $11: 367-381$

1973 Taxonomy. morphology and suggested phylogen! of the dinotlagellate genus Druggedum. Geoscience and Man 7:47-55.

1976 Neocoman dinoflagellate zonation in the western North Atlantic. Micropaleontology 21:373-392

HATCKEL, E

1894 Entuurf eines natürlichen Sivems der Organismen aut Grund ihrer Stammesgeschichte, Erster Teil: Swtematische Phylogenic der Protusten und Ptlanzen. Berlin, G Reiner. $400 \mathrm{pp}$.

HARLAVD, R , S J MORBEY and W A S SARJIANT

1975 A revision of the Triassic to lowest Jurassic dinoflagellate Rhaetogonvuslax. Palaeontology 18:847-864.

HARLAND, R and W A S.ARJEANT

1970 Fossil freshwater microplankton (dinotlagellates and acritarchs) from Flandrian (Holocene) sediments of Victoria and Western Australia. Proceedings of the Royal Society of Victoria $83: 211-234$.

HARRIS. $\| k$

1974 Tertiary non-marine dinoflagellate cyst assemblages from Australia. Geological Society of Australia, Special Publication 4:159-166

IOA.VIDES, \S . G.N STAVRINOS, and C. DOW:II

1977 Kimmeridgian microplankton from Clavel's Hard, Dorset. England. Micropaleontology 22:443-478

JAIV, $K P$ and $P$ NILLEPIED

1973 Cretaceous microplankton from Senegal Basin, N.W. Africa. 1. Some new genera, species and combinations of dinoflagellates. Palaeobotanist 20:22-32.

JOH.NSON, C.D. and LV HILLS

1973 Microplankton zones of the Savik Formation (Jurassic), Axel Heiberg and Ellesmere Islands, District of Franklin. Bulletin of Canadian Petroleum Geology $21: 178-218$.

KLEUE $\backslash$ T. $K$ W

1957 Revision der Gattungszugehörigkeit einiger in die Gattung Gimnodinium Stein eingestufter Arten jurassischer Dinoflagellaten. Neues Jahrbuch für Geologie und Paläontologie, Monatshefte 1957(9):408-410.

1960 Dinoflagellaten und Hystrichosphaerideen aus dem unteren und mittleren Malm Südwestdeutschlands. Palaeontographica (Abi. A) 114:1-104.

KLLUPP. B

1953 Beıtrag zur Kenntnis der Mikrofossilien des mittleren und oberen Eozàn. Palaeontographica (Abt. A) 103:377-406.

KRLTISCH, W:

1962 Die Mikroflora der Geiseltalbraunkohle Teil III. Süsswasserdinoflagellaten aus subaquatisch gebildeten Bläterkohlenlagen des mitteren Geiseltales. Hallesches Jahrbuch für Mitteldeutsche Erdgeschichte 4:40-45

LEFINGWELL, H A and $R$ P MURGAV

1977 Restudy and comparison of the dinoflagellate cyst genus Carpodinum to that of Prosnodinium $\mathrm{n}$. gen. Journal of Paleontology S1.288-302.
LEJI VI. ( IRPI VIII R, V

1438 Letude microscopique des sllex. Areoligera: nouveau genre d'Hystrichosphaeridec (skréme note). Annales de la Societe Géologique de Belgique 62.B163-B174

LF VIIN, J $h$ and $G L$ WIILAMS

1973 Fossil dinoflagellates: index to genera and species. Geolog!cal Survey of Canada, Paper 73-42:1-176.

1976 A monograph of fossil peridinioud dinoflagellate cysts Bedford Institule of Oceanography, Report B1-R-7516: $1-237$

1977a Fossil dinoflagellate genus lsabelidintum nom. nov. Palynology 1:167-168.

$1977 \mathrm{~b}$ Fossil dinoflagellates: index to genera and species. Bedford Institute of Oceanography, Report BI-R-77-8:1-209

1978 Alphabetical listıng of fossil dinocyst species. Bedford Institute of Oceanography, Report BI-R-78-4:1-44

LOFAIICH. A R JR and A R LOFBLICH III

1966 Index to the genera, subgenera, and sections of the Pyrmophyta. Studies in Tropical Oceanography 3:1-94.

1968 Index to the genera, subgenera, and sections of the Pyrrhophyta, 1l. Journal of Paleontology 42:210-213.

MANTELL, G A

1854 The medals of creation; or, first lessons in geology, and the study of organic remains. 2nd ed. London, R. Clay. 2 vols. $930 \mathrm{pp}$

MANUM, S

1960 Some dinoflagellates and hystrichosphaerids from the Lower Tertiary of Spitsbergen. Nytt Magasin for Botanikk $8: 17-26$

MAINTYRE, D J

1975 Morphologic changes in Deflandrea from a Campanian section, District of Mackenzie, N.W.T., Canada. Geoscience and Man 11:61-76.

McLEAN, D.M

1972 Cladopixidium septatum, n. gen., n. sp., possible Tertiary ancestor of the modern dinoflagellate Cladopvis hemibrachiata Balech, 1964. Joumal of Paleontology 46:861863.

1973a Emendation and transfer of Eiserrackia (Pyrhophyta) from the Microdiniaceae to the Gonyaulacaceac. Geologiska Föreningeni Stockholm, Förhandlingar 95:261-265.

$1973 \mathrm{~b}$ A problematical dinoflagellate from the Tertiary of Virginia and Maryland. Palacontology 16:729-732

MILLIOUD, M.E

1969 Dinoflagellates and acritarchs from some western European Lower Cretaceous type localities. In Bronnimann, P. and H.H. Renz, eds., Proceedings of the 1st Conference on Planktonic Microfossils, Geneva, 1967, vol. 2, pp. 420 434

MORBE:Y, S J

1975 The palynostratigraphy of the Rhaetian Stage. Upper Triassic in the Kendelbachgraben. Austria. Palaeontographica (Abt. B) 152.1-75

1975 Some Farly Cretaceous organic-walled microplankton from the Great Australian Basin. Australia. Joumal and Proceedings of the Royal Socicty of Neu South Wales 108: $157 \quad 167$. 
SIORGE \ROTH. P

1966 Mikrofossilien und Konkretionen des nordwesteuropäischen Untereozans. Palaeontographica (Abt. B) 119:1-53.

1968 Zur Kenntnis der Dinoflagellaten und Hystrichosphaeridien des Danien. Geologisches Jahrbuch 86:533-578.

1970 Dinoflagellate cysts from the Lias Delta of Lühnde/Germany. Neues Jahrbuch für Geologie und Paläontologie, Abhandlungen 136:345-359.

NEALE. JW and U A.S SARJEANT

1962 Microplankton from the Speeton Clay of Yorkshire. Geological Magazine 99:439-458

1978a Phylogeny and a revised supra-generic classification for Triassic-Quaternary organic-walled dinoflagellate cysts (Pyrrhophyta). Part I. Cyst terminology and assessment of previous classifications. Neues Jahrbuch für Geologie und Paläontologie, Abhandlungen 155:300-317.

1978b Phylogeny and a revised supra-generic classification for Triassic-Quaternary organic-walled dinoflagellate cysts (Pyrrhophyta). Part II. Families and sub-orders of fossi dinoflagellates. Neues Jahrbuch für Geologie und Paläontologie, Abhandlungen 156:1-30.

NORRIS, G and W A S SARJEANT

1965 A descriptive index of genera of fossil Dinophyceae and Acritarcha. Neu. Zealand Geological Survey, Paleontological Bulletin 40:1-72.

NORV'TCK, M S

1973 The microplankton genus Disphaeria Cookson and Eisenack emend. Australia, Bureau of Mineral Resources, Geology and Geophysics, Bulletin 140:45-46.

PASCHER, A

1914 Über Flagellaten und Algen. Berlin deutsche Botanische Gesellschaft $32: 136-160$.

POCOCK. S.A.J

1972 Palynology ol the Jurassic sediments of western Canada. Part 2. Marine species. Palaeontographica (Abt. B) 137:85-153

RIEGEL. W

1974 New forms of organic-walled microplankton from an Upper Cretaceous assemblage in southem Spain. Revista Española de Micropaleontologia 6:347-366.

SARJI:ANT, W' A S

1961a Microplankton from the Kellaways Rock and Oxford Clay of Yorkshire. Palaeontology 4:90-118

1961b Sistematophora Klement and Polvsiephanosphaera Sarjeant. Journal of Paleontology 35:1095-1096

1962 Upper Jurassic microplankton from Dorset, England. Micropaleontology 8:255-268

1966 Dinoflagellate cysts with Gonaulax-type tabulation. Bulletin of the British Museum of Natural History (Geology), Supplement 3:107-156.

1967 The genus Palacoperidinium Deflandre (Dinophyceac). Grana Palynologica 7:243-258.

1968 Microplankton from the Upper Callovian and Lower Oxfordian of Normandy. Revue de Micropaléontologic 10:221-242

1969 Taxonomic changes. Bulletin of the British Museum ol Natural History (Geology), Appendix to Supplement $3: 7$ 15.
1970 The genus Spiniferites Mantell, 1850 (Dinophyceae). Grana 10:74-78

1974 Fossil and living dinoflagellates. London. Academic Press. 182 pp.

1975a Jurassic dinoflagellate cysts with epitractal archaeopyles: a reconsideration. Grana 14:49-56.

1975b Hapsidaulas, new genus of dinoflagellate cysts from the Jurassic (Bathonian) of the Isle of Skye. Scottish Joumal of Geology 11:143-149.

1976 Energlynia, new genus of dinoflagellate cysts from the Great Oolite Limestone (Middle Jurassic: Bathonian) of Lincolnshire, England. Neues Jahrbuch für Geologie und Paläontologie, Monatshefte 1976(3): 163-173.

SARJEANT. W.A.S and C. DOWNII

1966 The classification of dinoflagellate cysts above the generic level. Grana Palynologica 6:503-527.

1974 The classification of dinoflagellate cysts above the generic level: a discussion and revisions. Birbal Sahni Institute of Paleobotany, Special Publication 3:9-32.

SCHLTT, F

1896 Peridiniales (Peridiniaceae, Dinoflagellata, Cilioflagellata, arthrodele Flagellaten). In Engler, A. and K. Prantl, eds., Die natürlichen Pflanzenfamilien nebst ihren Gattungen und wichtigeren Arten. I Teil, Abteilung la und 1b. Leipzig, Engelmann. 1900

STEIDINGER, $\mathrm{K}$ A. and J.T DAVIS

1967 The genus Pyrophacus with a description of a new form. Florida Board of Conservation, Division of Salt Water Fisheries, Leaflet Series 1, Part 1, no. 3:1-8

STEIN, F

1883 Der Organismus der Infusionsthiere nach eigenen Forschungen in systematischer Reihenfolge. Abteilung 111, Hälte II, Die Naturgeschichte der Arthrodelen Flagellaten. Leipzig. Engelmann. 30pp.

STOVER. L H

1975 Observations on some Australian Eocene dinoflagellates. Geoscience and Man 11:35-45.

STOVER LE. and W.R EVITT

1978 Analyses of Pre-Pleistocene organic-walled dinoflagellates. Stanford University Publications, Geological Sciences 15:1-298.

STOVER, L.E., W A S SARJEANT and W S. DRUGG

1977 The Jurassic dinoflagellate genus Stephane/vron: emendation and discussion. Micropaleontology 23:330-338.

VOZZHINNIKOVA, T.F

1961 A contribution to the taxonomy of fossi] Peridinidae. [In Russian]. Doklady Akadenia Nauk SSSR 139:14611462. [Translation in American Geological Institute. Proceedings of the Academy of Sciences of the U.S.S.R., Earth Science Section, [963, pp. 852-853.]

1963 Pirrofitovye Vodorosli. [Phylum Pyrrhophyta]. In Orlov. A. Yu, ed. Osnovy Paleontologii [Fundamentals of Paleontology] 14:179-185

1965 Vvedenic $v$ izuchenic iskopaemykh peridıneevykh vodorosli. [Introduction to the study of fossi] peridinian algae.] Akademiya Nauk SSSR, Sibirskoye Otdeleniye, Institut Geologii i Geofiziki, Trudy. $156 \mathrm{pp}$ 
1967 Iskopayemye peridinei yurskikh, melovykh I paleogenovyk otlozheniy SSSR. (Fossil peridinians of the Jurassic, Cretaceous and Paleogene deposits of the U.S.S.R.] Ahademiya Nauk SSSR, Sibirshoye Ot deleniye. Institut Geologin i Geotiziki. Trudy. 347 pp.

WALL. D

1967 Fossil microplankton in deep-sea cores from the Caribbean Sea. Palaeontolog! 10:95-123.

WALL. D, B DALE and K HARADA

1973 Descnptions of new fossil dinoflagellates from the Late Quaternary of the Black Sea. Micropaleontology 19:1831.

W.ARRY IS

1973 Form and variation of the dinoflagellate Sirmiodmium grossi Alberi, from the Upper Jurassic and Lower Cretaceous of California. Joumal of Paleontology $47: 101-114$

WETZEL, O

1933 Die in organischer Substanz erhaltenen Mikrofossilien des baltischen Kreide-Feuersteins mit einem sedimentpetrographischen und stratigraphischen Anhang. Palaeontographica (Abt. A) 78:1-110.

1960 Eine neue Dinoflagellaten-Gruppe aus dem baltischen Geschiebefeuerstein. Naturwissenschaftlicher Verein für Schleswig Holstein, Schriften 31:81-86.
Wilitils N I)

1969 Two lower Cretaceous dnoflagellate species from Alas ha. Micropaleontology 15: 145-150.

1972 Two new Lower Cretaceous dinoflagellate genera from southem Alaska (U.S.A.). Review of Palaeobotany and Palynology 14:297-308.

1975 The dinoflagellate family Pareodiniaceae: a discussion. Geosclence and Man 11: 95-115.

WILIIAMS. GL and JP BBUJAK

1977a Mesozoic-Cenozoic dinocysts: North Atlantic distribution. Coloquio Internacional de Palinologia, Leon, Spaın, Abstracts, p. 39.

1977h Dinocyst diversity in time. American Asscriation of Stratigraphic Palynologists 10th Annual Mceting. Tulsa, Oklahoma, Abstracts, p. 31.

WILLIAMS. GL and C DOWNIt

1966 The genus Histrichokolpoma. Bulletin of the British Museum of Natural History (Geology), Supplenient 3:176181.

1966b Further dinoflagellate cysts from the London Clay. Bulletin of the British Museum of Natural History (Geology), Supplement 3:215-236.

WILLIANS. G I. . W A S SARJEANT and E. I KIOSON

1973 A glossary of the terminology applied to dinotlagellate amphiesma and cysts and acritarchs. American Association of Stratigraphic Palynologists, Contribution Series $2: 1-222$.
All figures conform to the following magnifications:

$\begin{array}{llc}\begin{array}{l}\text { Size Range } \\ <25 \mu \mathrm{m}\end{array} & \text { Scale } & \begin{array}{c}\text { Magnification } \\ \text { (Approx.) }\end{array} \\ 25-50 \mu \mathrm{m} & \text { Scale D } & 2000 \times \\ 51-100 \mu \mathrm{m} & \text { Scale C } & 1000 \times \\ >100 \mu \mathrm{m} & \text { Scale B } & 750 \times \\ & \text { Scale A } & 500 \times\end{array}$

Scales are indicated in brackets behind the name of the type species; e.g. Gonvaulacista jurassica (B). A $50 \mu \mathrm{m}$ bar corresponding to each scale (A, B, C, and D) is inserted on Plate I to facilitate measurements.

Whenever possible the respective holotype of the type species has been illustrated. In some cases illustrations of paratypes or schematic drawings are given instead, usually if the holotype did not clearly exhibit the generic features or if it was poorly illustrated originally. Following the scale, holotypes have been designated as " $h$ ", paratypes as "p" , and schematic drawings as "s". e.g. Goniaulacista jurassica (B), h.

In general, no reference has been made to the literature on basionyms or emendations of the type species. 


\section{Family Rhaetogonyaulacaceae (1-14)}

Fig. 1 Dapcodinium priscum Evitt, 196la (C), s; a. ventral, b. dorsal, c. apical, d. antapical.

Fig. 2 Egmontodinium polyplacophorum Gitmez and Sarjeant, 1972, (B), s; a. ventral, b. dorsal.

Fig. 3 Hebecysta brevicornuta Bujak and Fisher, 1976, (B); a. h, ventral, b. p, dorsal.

Fig. 4 Heibergella asymmetrica Bujak and Fisher, 1976, (B), h.

Fig. 5 Luehndea spinosa Morgenroth, 1970, (C), h.

Fig. 6 Mendicodinium reticulatum Morgenroth, 1970, (C), h. 


\section{Rhaetogonyaulacaceae}
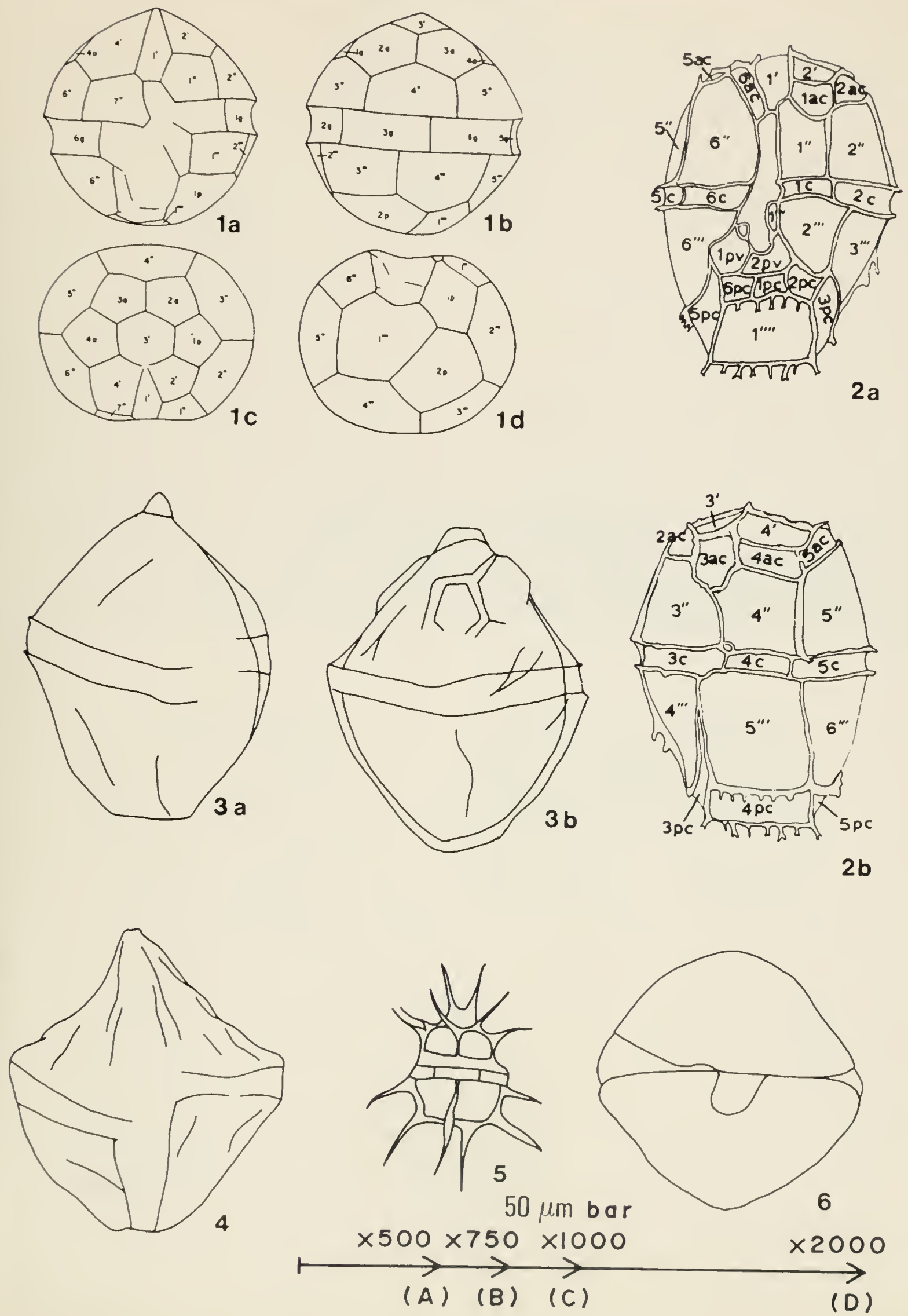


\section{Family Rhaetogonyaulacaceae (cont.)}

Fig. 7 Nelchinopsis kostromiensis (Vozzhennikova) Wiggins, 1972, (B); a. h, dorsal, b. s, ventral, c. s, dorsal.

Fig. 8 Noricysta fimbriata Bujak and Fisher, 1976, (C); a. h, ventral, b. s, ventral, c. s, dorsal.

Fig. 9 Rhaetogonyaulax rhaetica (Sarjeant) Loeblich and Loeblich, 1968, (B); a. h, ventral, b. s, oblique ventral, c. s, dorsal. 

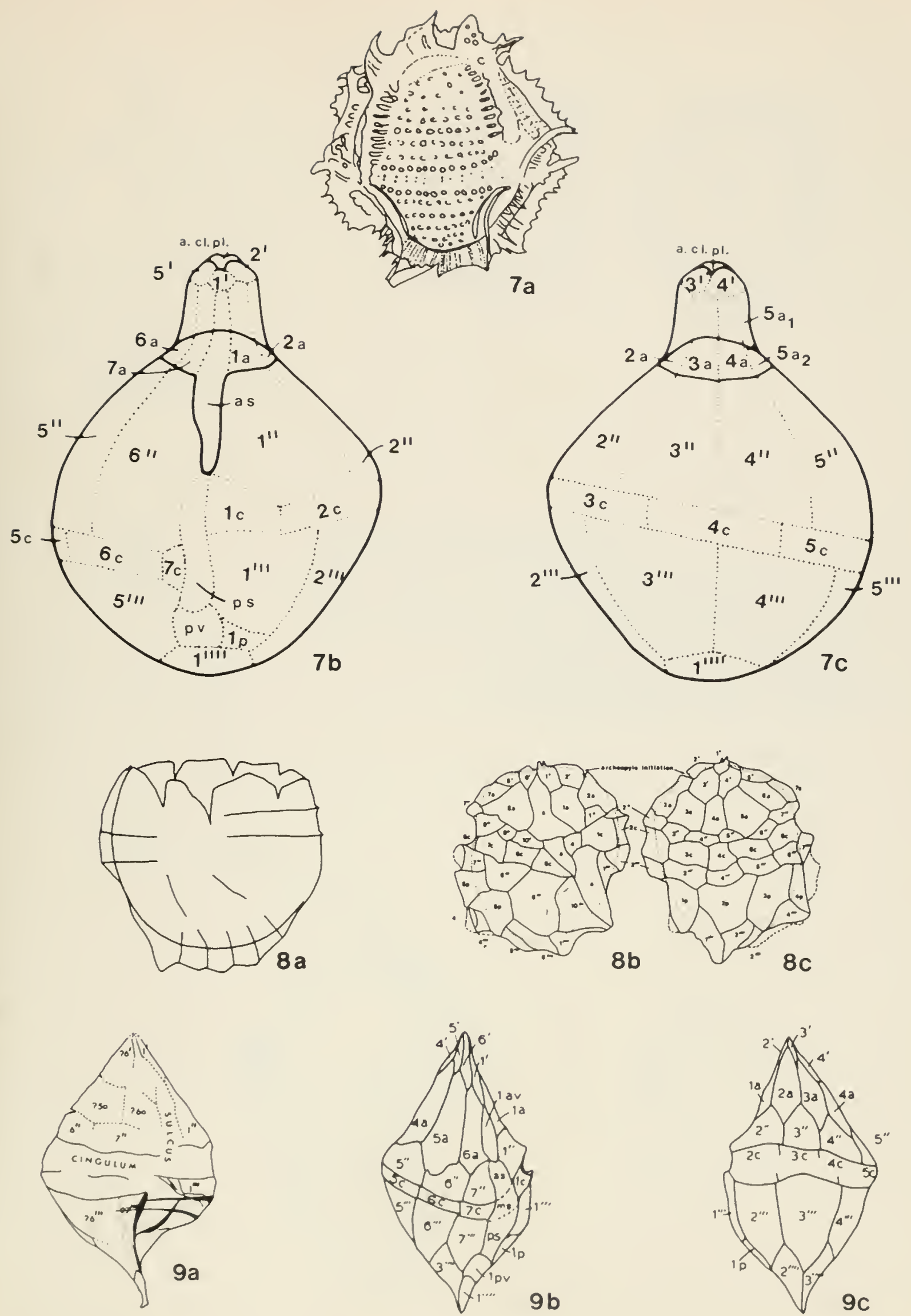


\section{Family Rhaetogonyaulacaceae (cont.)}

Fig. 10 Pluriarvalium osmingtonense Sarjeant, 1962, (A), s; a. ventral, b. dorsal.

Fig. 11 Subtilidinium minutum Morgenroth, 1968, (D), s; a. ventral, b. dorsal.

Fig. 12 Suessia swabiana Morbey, 1975, (C), s;

Fig. 13 Sierdrupiella septentrionalis Bujak and Fisher, 1976, (B), h.

Fig. 14 Valvaeodinium armatum Morgenroth, 1970, (C), h. 

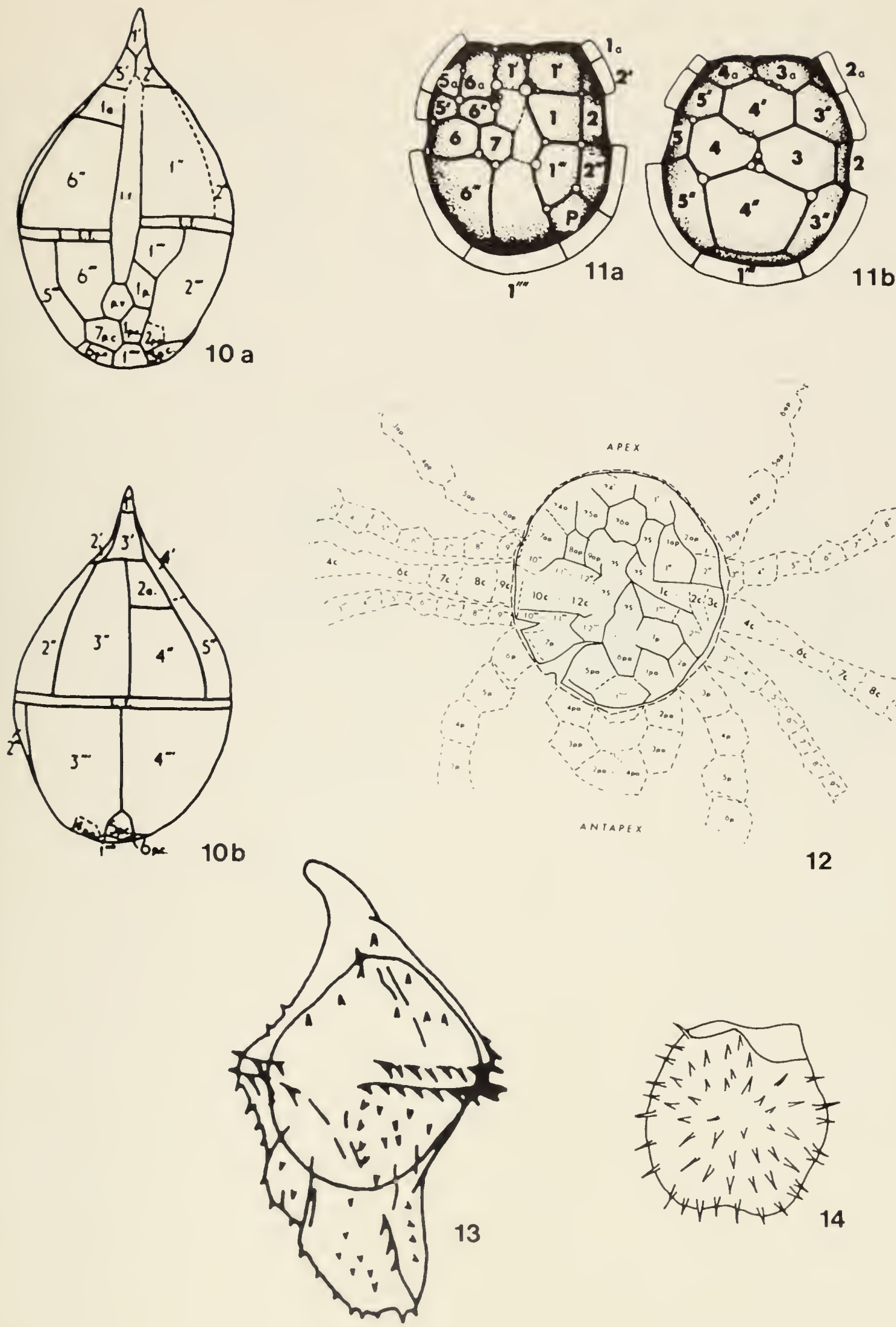


\section{Family Phallocystaceae (15-18)}

Fig. 15 Comparodinium koessenium Morbey, 1975, (C), h.

Fig. 16 Dodekovia syzygia Dörhöfer and Davies, 1979, (C), h; a. ventral, b. dorsal.

Fig. 17 Phallocysta eumekes Dörhöfer and Davies, 1979, (C), s.

Fig. 18 Susadinium scrofoides Dörhöfer and Davies, 1979, (C), h; a. dorsal, b. ventral. 


\section{Phallocystaceae}
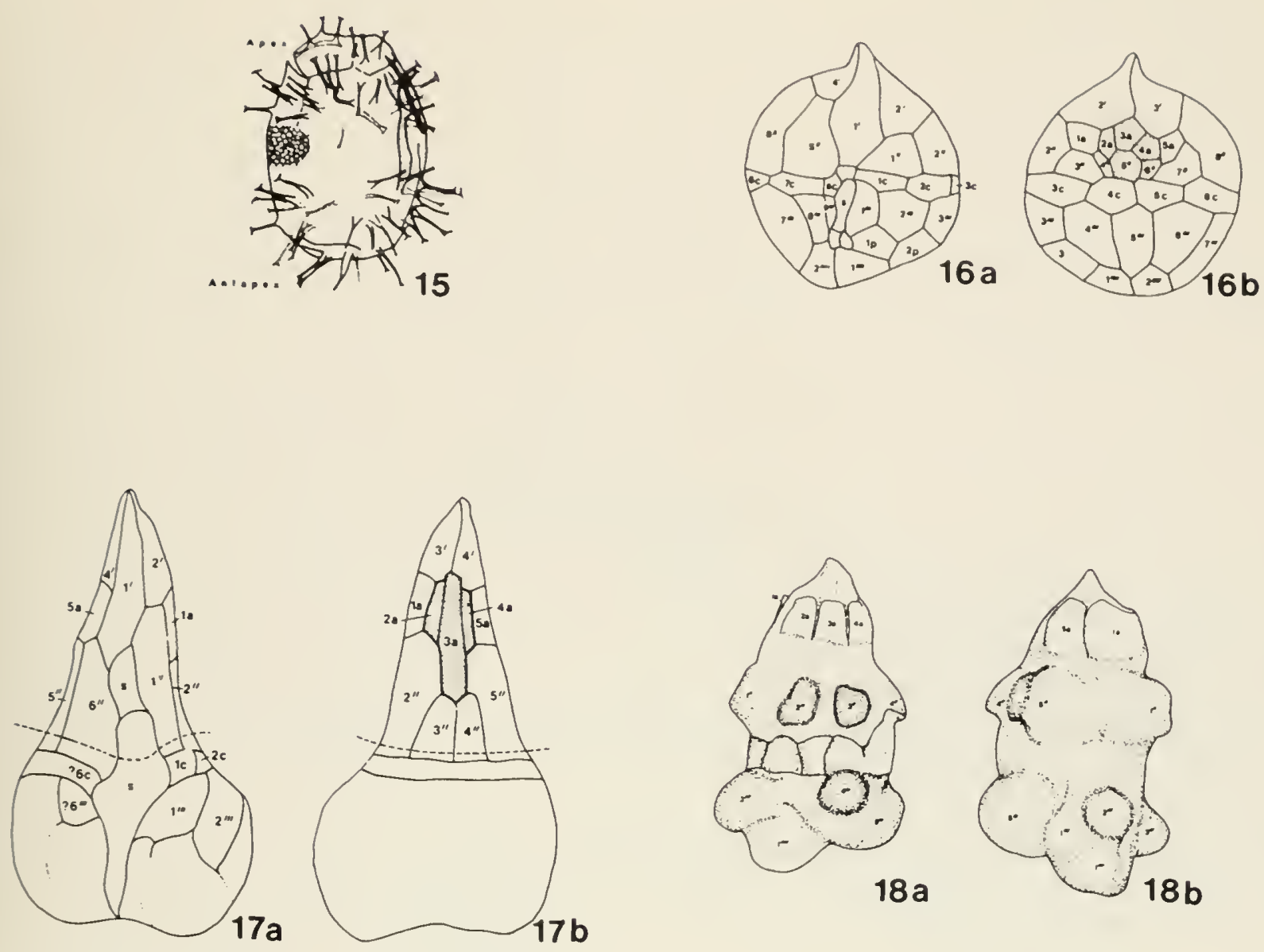


\section{Family Pareodiniaceae $(19-26)$}

Fig. 19 Broomea ramosa Cookson and Eisenack, 1958, (A), h.

Fig. 20 Caligodinium amiculum Drugg, 1970, (B), h.

Fig. 21 Camtulodinium speciosum Alberti, 1961, (B), h.

Fig. 22 Glomodinium reticulopilosum Dodekova, 1975, (C), h.

Gochteodinia villosa (Vozzhennikova) Norris, 1978b, not illustrated-refer to holotype in Vozzhennikova (1967), pg. 12, figs. 3a, b. pg. 5, fig. 1.

Fig. 23 Komew'uia glabra Cookson and Eisenack, 1960b (A), h.

Fig. 24 Moesiodinium raileanui Antonescu, 1974, (C), h; a. dorsal, b. ventral.

Fig. 25 Paragonyaulacysta calloviensis Johnson and Hills, 1973, (B), h; a. ventral, b. dorsal.

Fig. 26 Pareodinia ceratophora Deflandre, 1947, (B), h. 


\section{Pareodiniaceae}
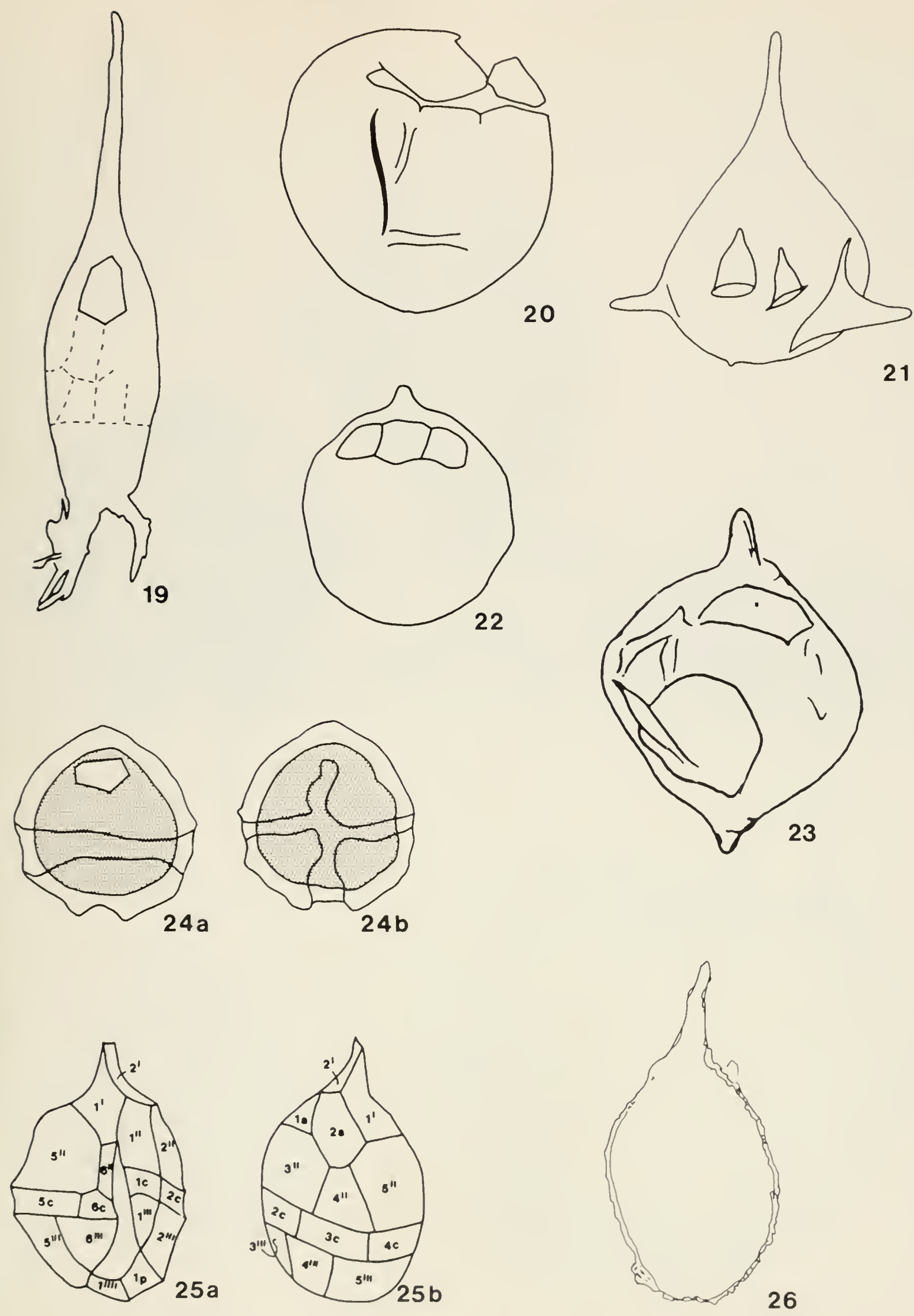


\section{Family Pseudoceratiaceae (27-38)}

Fig. 27 Aprobolocysta eilema Duxbury, 1977, (B), h.

Fig. 28 Aptea polymorpha Eisenack, 1958, (B); a. h, ventral, b. s, dorsal, c. s, ventral.

Fig. 29 Canningia reticulata Cookson and Eisenack, 1960b, (B), h.

Fig. 30 Endoceratium ludbrookii (Cookson and Eisenack) Loeblich and Loeblich, 1966, (A), h.

Fig. 31 Heterosphaeridium conjunctum Cookson and Eisenack, 1968, (A), h. 


\section{Pseudoceratiaceae}
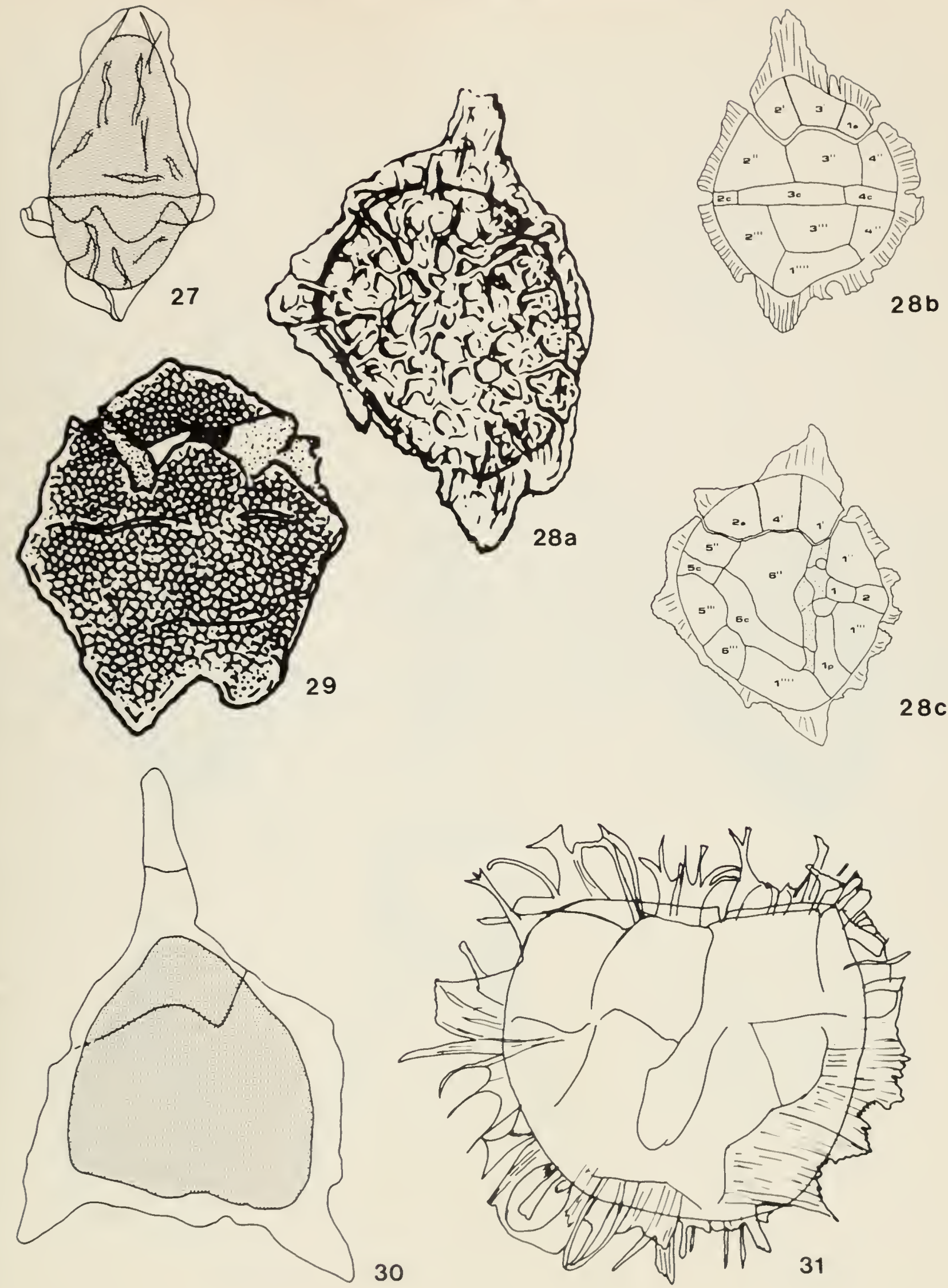


\section{Family Pseudoceratiaceae (cont.)}

Fig. 32 Imbatodinium kondratjevi Vozzhennikova, 1967, (A), h; a. dorsal, b. ventral.

Fig. 33 Muderongia mowhaei Cookson and Eisenack, 1958, (A), h.

Fig. 34 Odontochitina operculata (O. Wetzel) Deflandre and Cookson, 1955, (A), s.

Fig. 35 Odontochitinopsis molesta (Deflandre) Eisenack, 1961, (B), h.

Fig. 36 Phoberocysta neocomica (Gocht) Millioud, 1969, (A), h.

Fig. 37 Pseudoceratium pelliferum Gocht, 1957, (A), h.

Fig. 38 Xenascus ceratioides (Deflandre) Lentin and Williams, 1973, (A), h. 

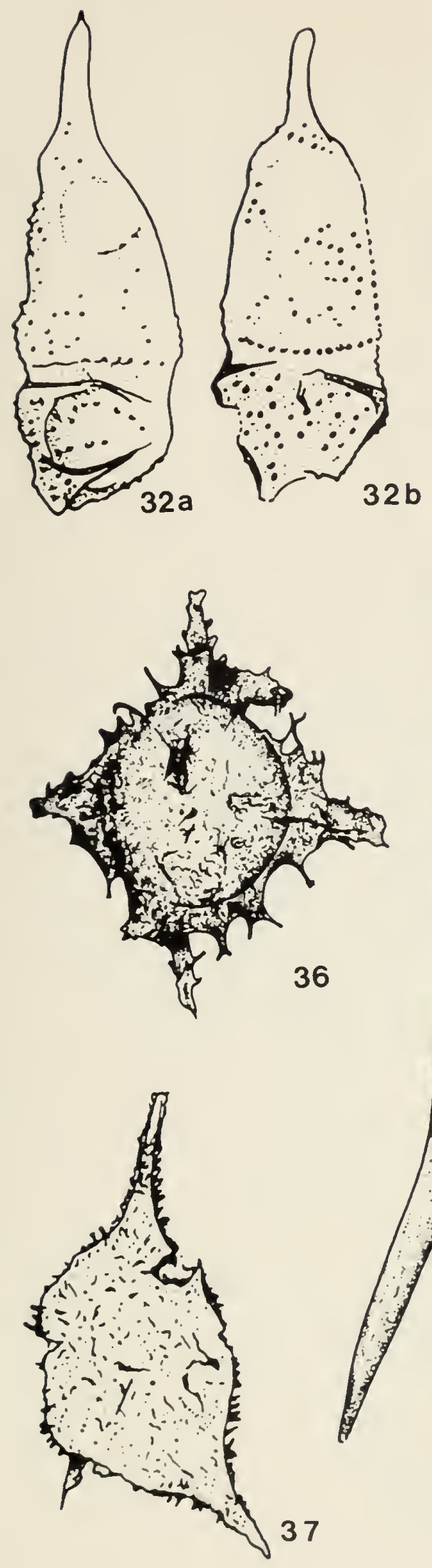
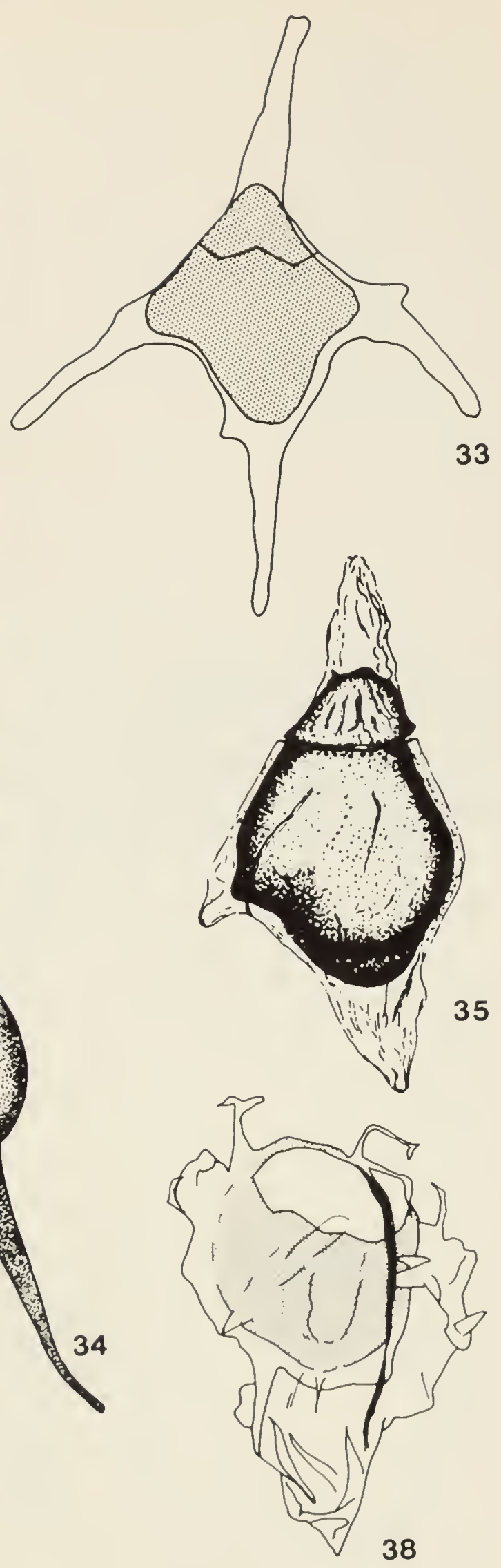


\section{Family Gonyaulacystaceae (39-54)}

Fig. 39 Acanthaulax venusta (Klement) Sarjeant, 1968, (B), h.

Fig. 40 Carpatella cornuta Grigorovitch, 1969, (A), h.

Fig. 41 Carpodinium granulatum Cookson and Eisenack, 1962b, (B), h; a. ventral, b. dorsal.

Fig. 42 Cribroperidinium sepimentum Neale and Sarjeant, 1962, (B), h; a. oblique ventral, b. dorsal.

Fig. 43 Cryptarchaeodinium calcaratum Deflandre, 1939, (C), h.

Fig. 44 Diacanthum hollisteri Habib, 1972, (B), h; a. dorsal, b. ventral. 


\section{Gonyaulacystaceae}
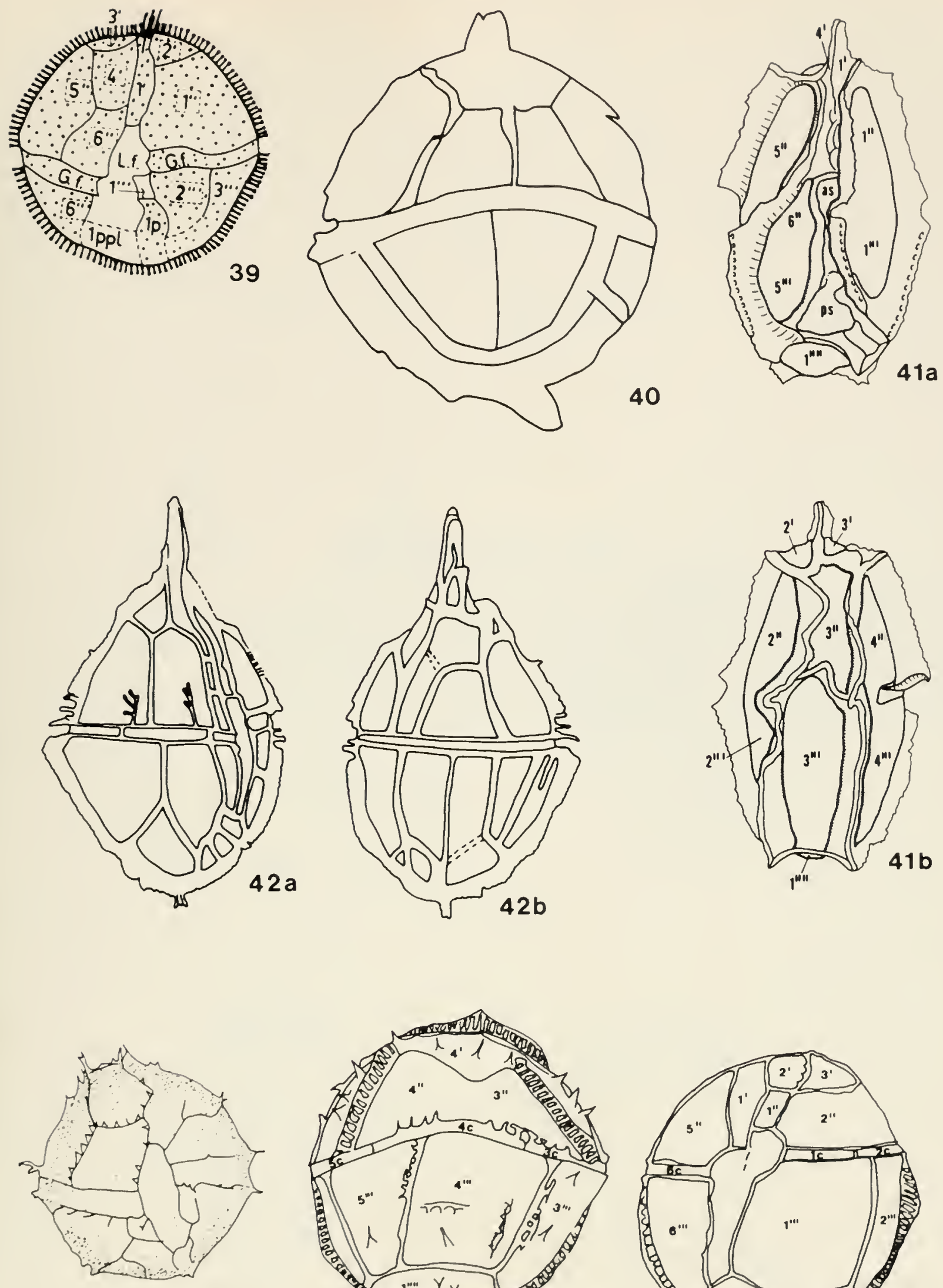

43
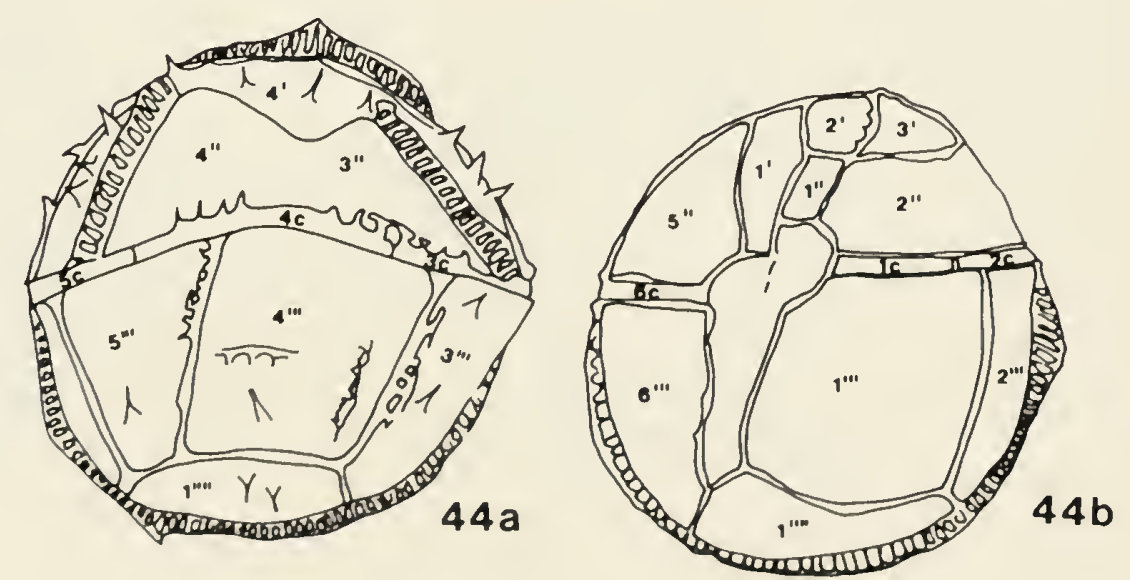


\section{Family Gonyaulacystaceae (cont.)}

Fig. 45 Druggidium apicopaucicum Habib, 1973, (B), h; a, ventral, b. dorsal.

Fig. 46 Gonyaulacysta jurassica (Deflandre) Norris and Sarjeant, 1965, (B), h; a. ventral, b. dorsal.

Fig. 47 Herendeenia pisciformis (Cookson and Eisenack) Wiggins, 1969, (B), s; a. dorsal, b. ventral.

Fig. 48 Heslertonia heslertonensis (Neale and Sarjeant) Sarjeant, 1966, (B), h.

Fig. 49 Leptodinium subtile Klement, 1960, (B), h; a. ventral, b. dorsal. 

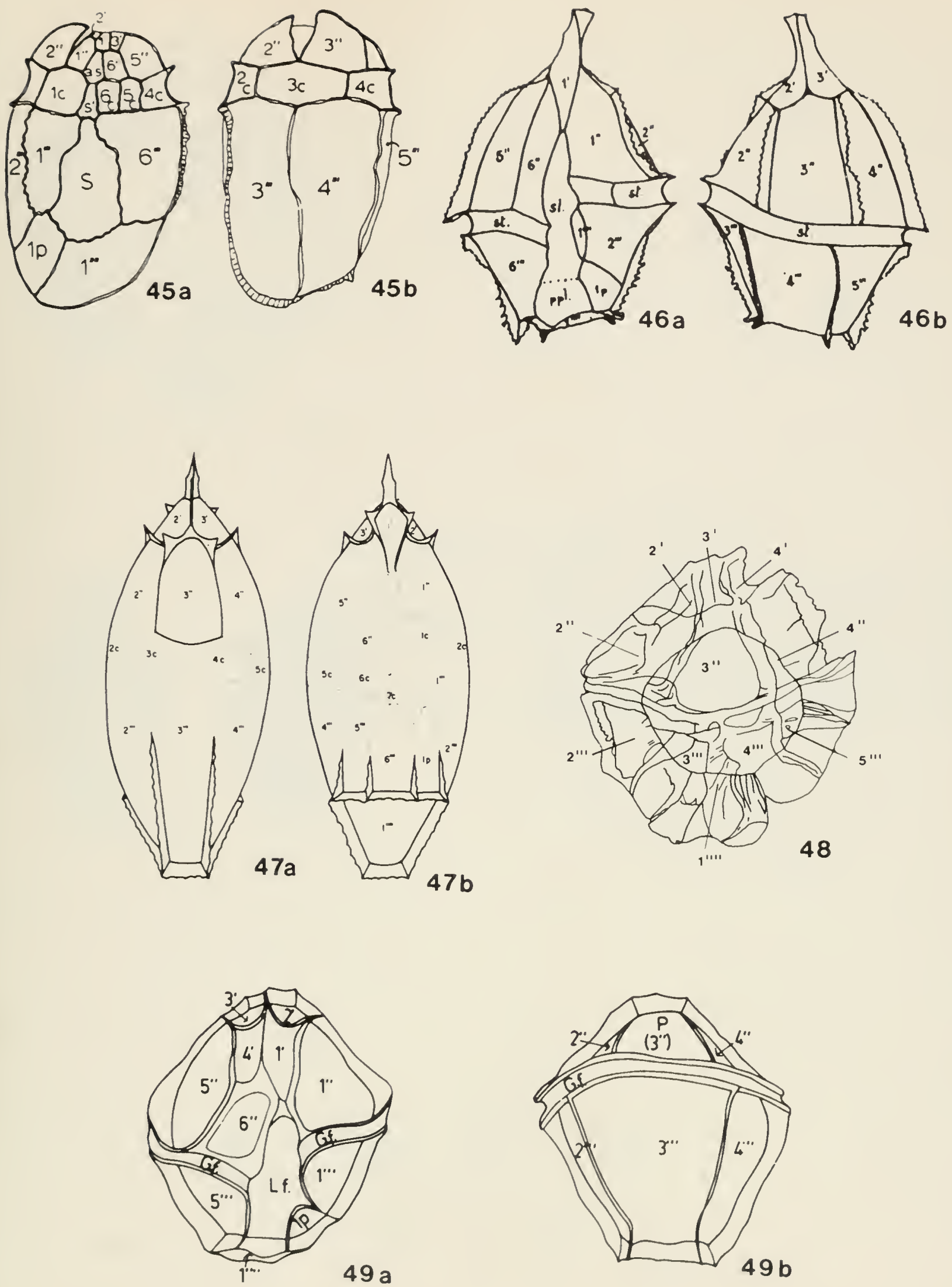


\section{Family Gonyaulacystaceae (cont.)}

Fig. 50 Muratodinium fimbriatum (Cookson and Eisenack) Drugg, 1970, (B), h.

Fig. 51 Occisucysta balia Gitmez, 1970, (B), h; a. ventral, b. oblique dorsal.

Fig. 52 Prionodinium alaskense Leffingwell and Morgan, 1977, (B), h; a. dorsal, b. ventral.

Fig. 53 Pterodinium aliforum Eisenack, 1958, (B), h.

Fig. 54 Rhynchodiniopsis aptiana Deflandre, 1935, (B), h; a. ventral, b. dorsal. 

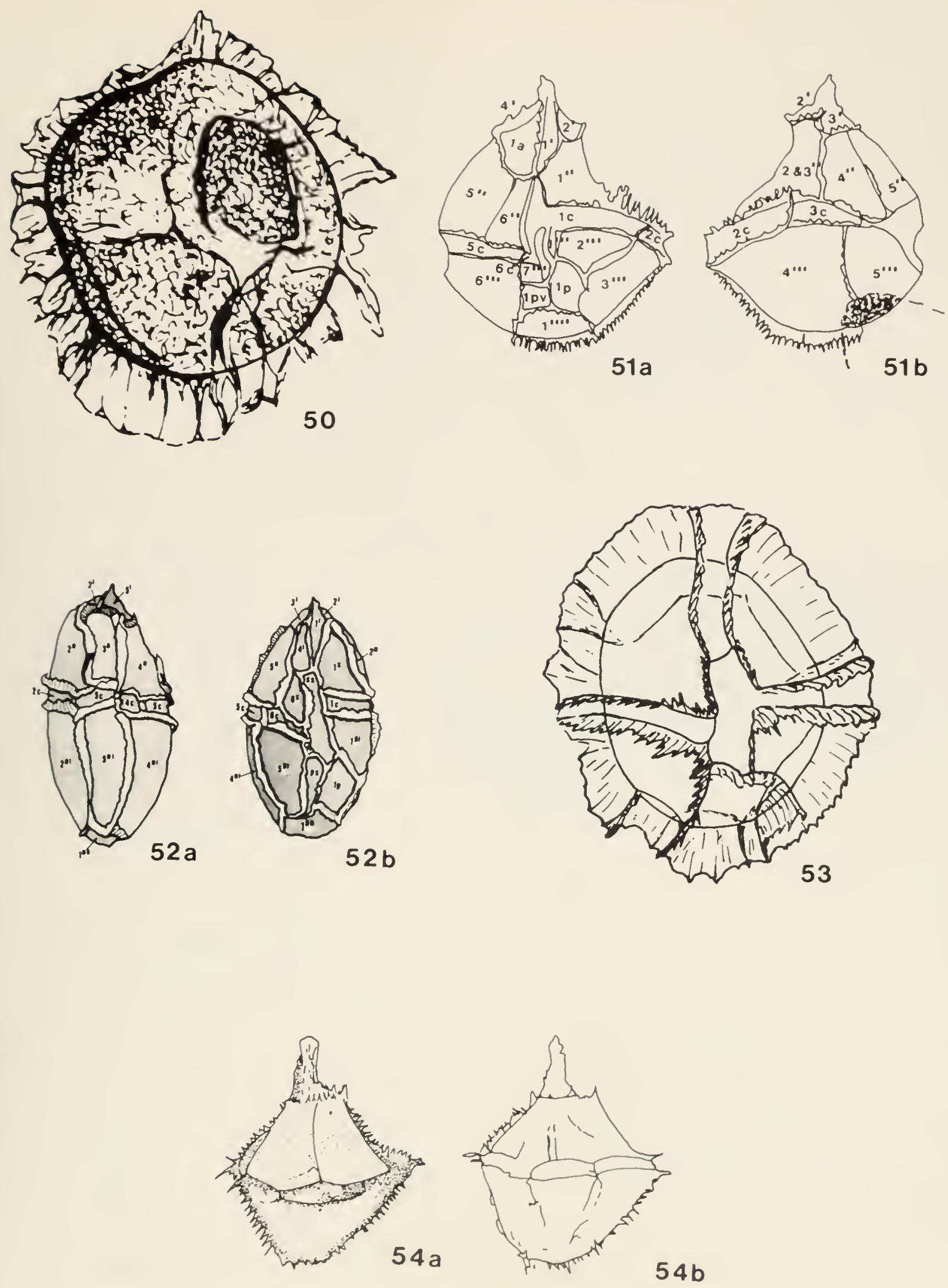


\section{Family Apteodiniaceae (55-67)}

Fig. 55 Apteodinium granulatum Eisenack, 1958, (B), h.

Fig. 56 Archeotectatum sarjeantii Habib, 1972, (C), h.

Fig. 57 Chytroeisphaeridia chytroeides (Sarjeant) Downie and Sarjeant, 1965, (B), h.

Fig. 58 Ellipsodinium rugulosum Clarke and Verdier, 1967, (C), s.

Fig. 59 Fusiformacysta salasii Morgan, 1975, (A), h.

Fig. 60 Kenleyia pachycerata Cookson and Eisenack, 1965b, (B), h.

Fig. 61 Lunatadinium dissolutum Brideaux and McIntyre, 1973, (B), h. 
6. Apteodiniaceae
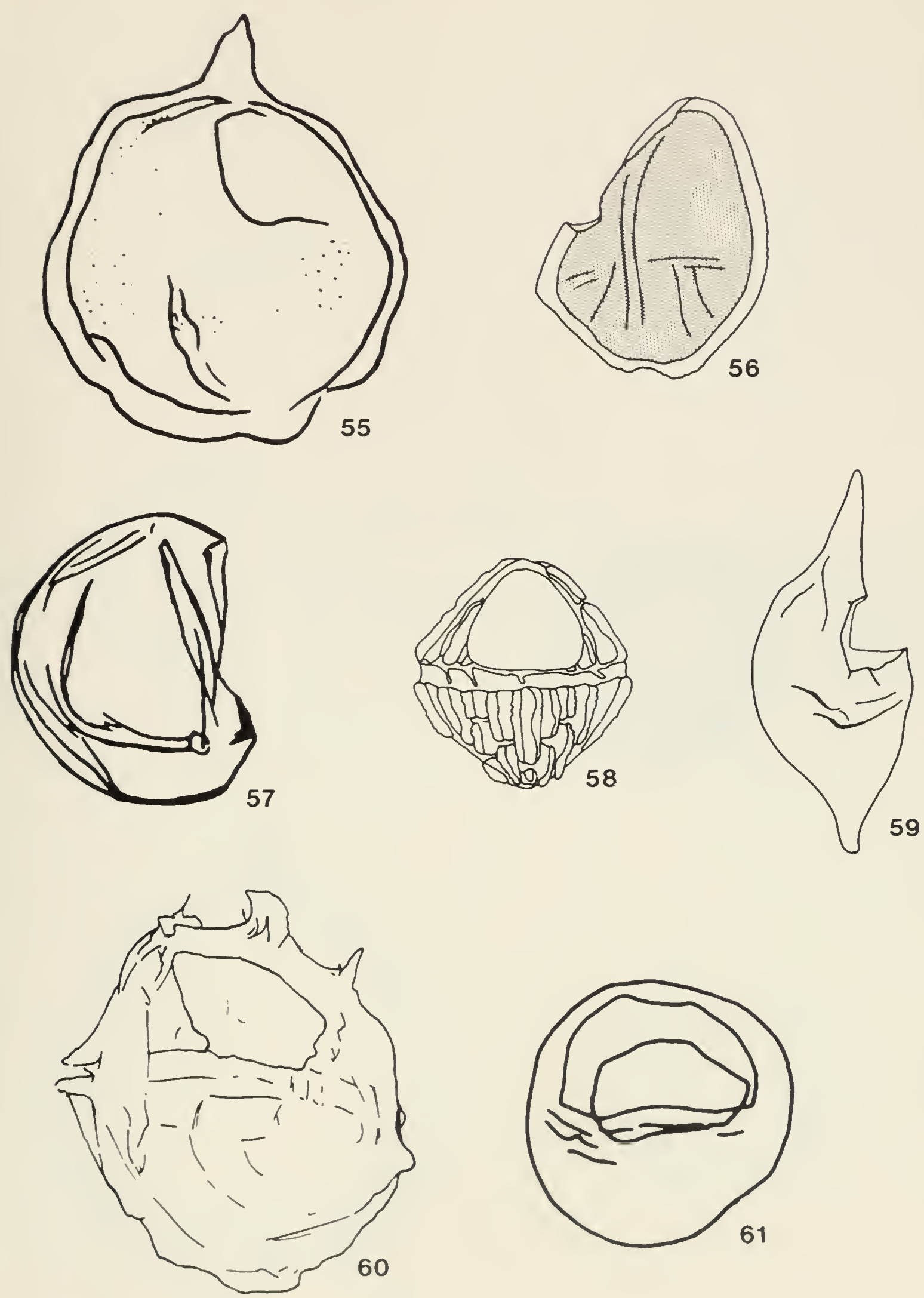


\section{Family Apteodiniaceae (cont.)}

Fig. 62 Pyxidinopsis challengerensis Habib, 1976, (B), h.

Fig. 63 Speetonia delicatula Duxbury, 1977, (B), h.

Fig. 64 Tapeinosphaeridium pericompsum loannides et al., 1977, (B), h.

Fig. 65 Tectatodinium pellitum Wall, 1967, (B), h.

Fig. 66 Trichodinium pellitum Eisenack and Cookson, 1960, (B), h.

Fig. 67 Xenicodinium densispinosum Klement, 1960, (B), h. 

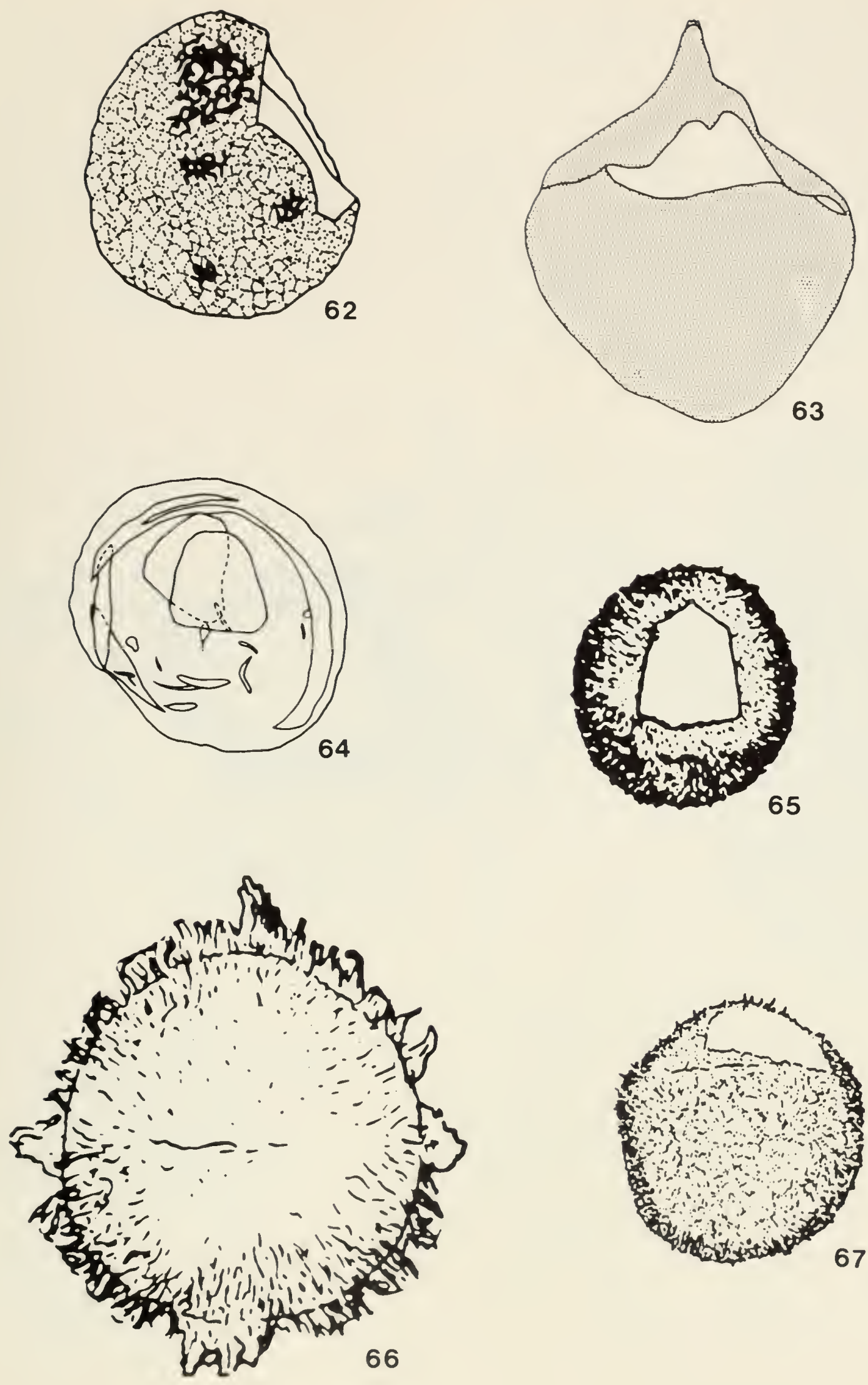


\section{Family Spiniferitaceae (68-77)}

Fig. 68 Achomosphaera ramulifera (Deflandre) Evitt, 1963, (B), h.

Fig. 69 Avellodinium falsificum Duxbury, 1977, (B), p; a. ventral, b. dorsal. (Family placement is questionable.)

Fig. 70 Cannosphaeropsis utinensis O. Wetzel, 1933, (A), h.

Fig. 71 Hapsidaulax margarethae Sarjeant, 1975b, (C), h; a. antapical, b. apical.

Fig. 72 Hapsocysta peridictya (Eisenack and Cookson) Davey, in press, (B), h.

Fig. 73 Heliodinium voigtii (Alberti) Sarjeant, 1966, (B), h. 


\section{Spiniferitaceae}
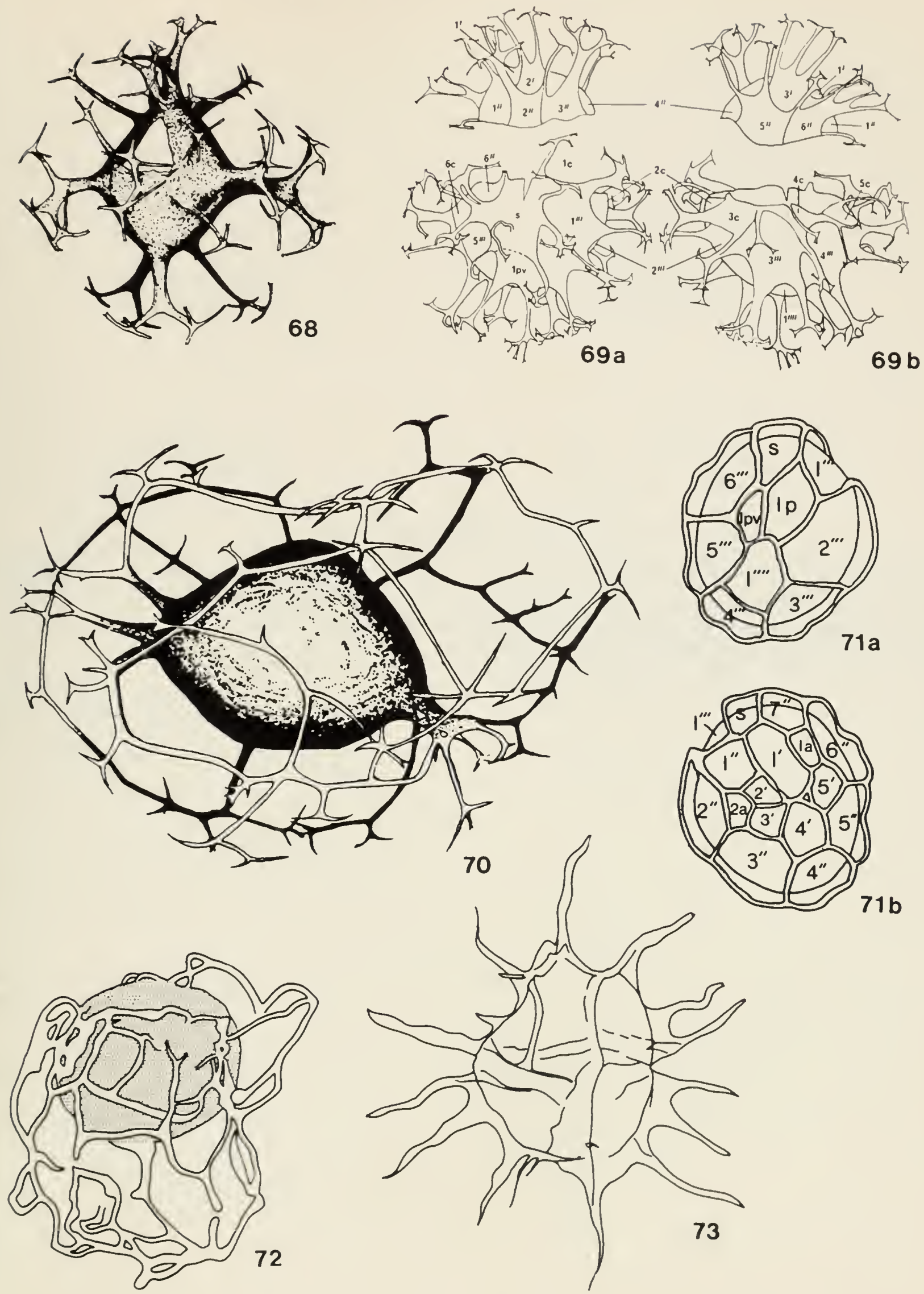


\section{Family Spiniferitaceae (cont.)}

Fig. 74 Hystrichodinium pulchrum Deflandre, 1935, (B), h; a. dorsal, b. ventral.

Fig. 75 Hystrichogonyaulax cornigera (Valensi) Sarjeant, 1969, (B); a. h, ventral, b. p, ventral.

Fig. 76 Nematosphaeropsis balcombiana Deflandre and Cookson, 1955, (B), h.

Fig. 77 Spiniferites ramosus (Ehrenberg) Mantell, 1854, (B), s. 

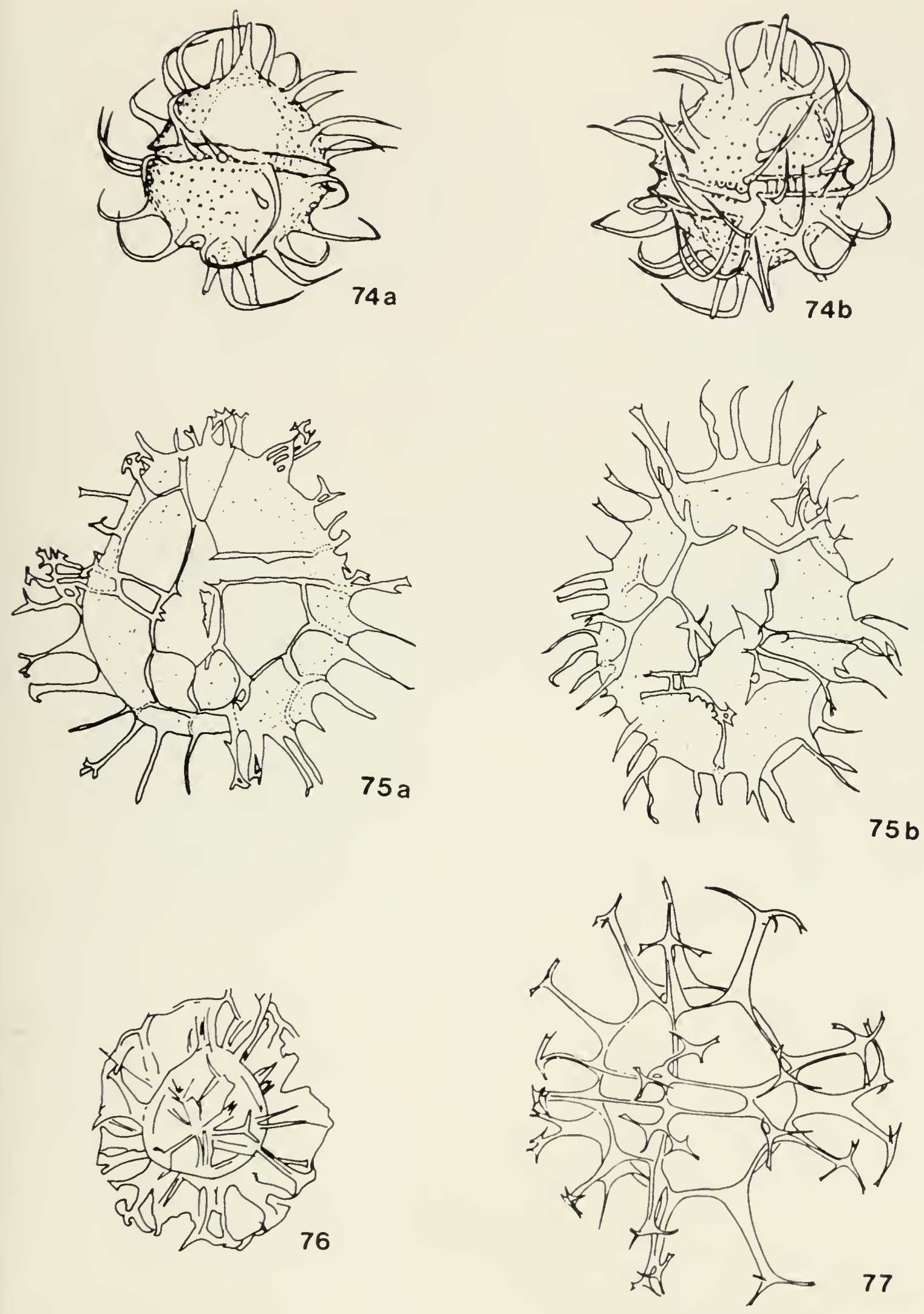


\section{Family Endoscriniaceae (78-92)}

Fig. 78 Actinotheca aphroditae Cookson and Eisenack, 1960a, (B), h.

Fig. 79 Athigmatocysta glabra Duxbury, 1977, (B), h; a. ventral, b. oblique dorsal.

Fig. 80 Codoniella campanulata (Cookson and Eisenack) Downie and Sarjeant, 1965, (B), h.

Fig. 81 Dimidiadinium dangeardii (Sarjeant) Brideaux, 1977, (B), h; a. ventral, b. dorsal. 
8. Endoscriniaceae
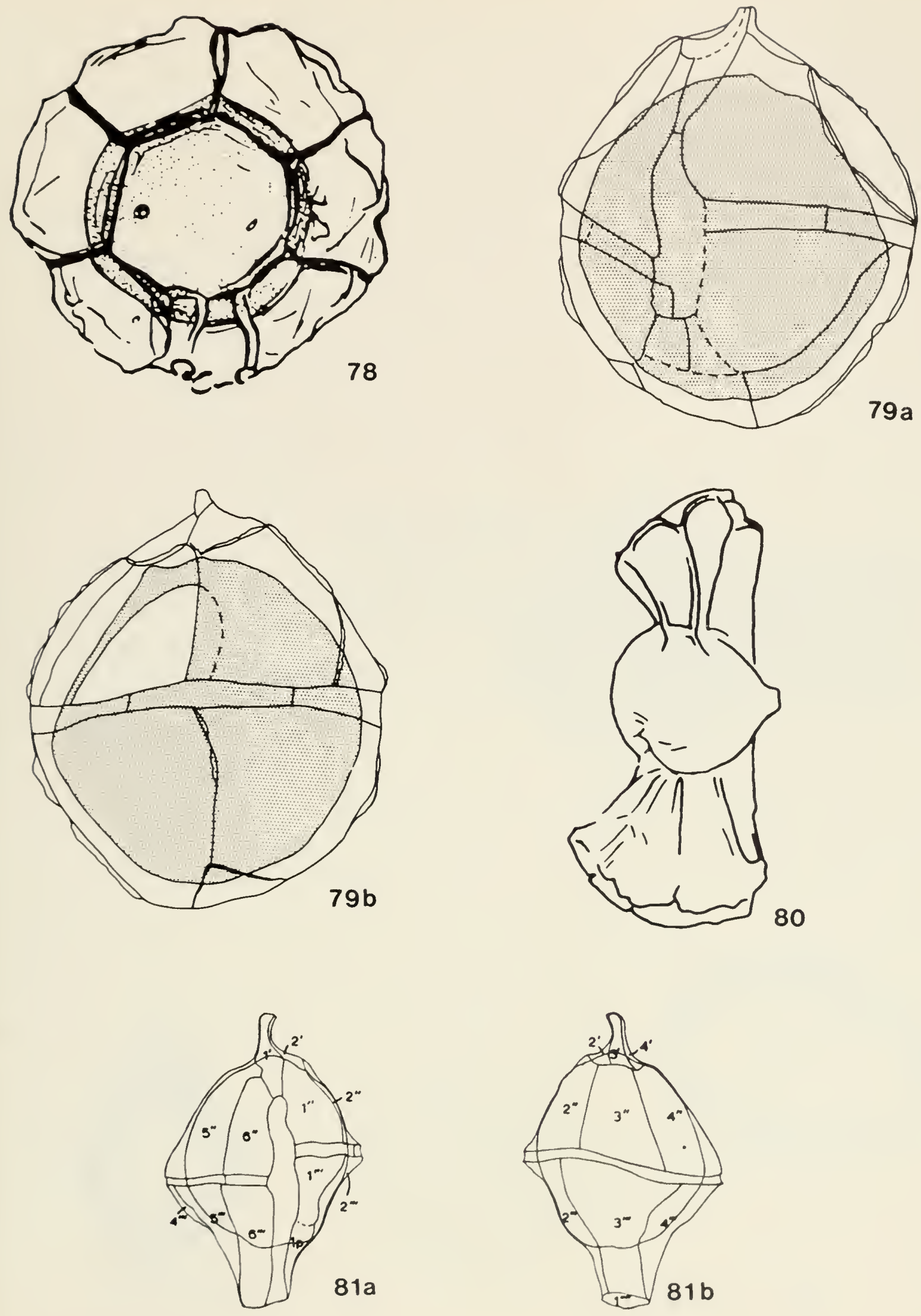


\section{Family Endoscriniaceae (cont.)}

Fig. 82 Endoscrinium galeritum (Deflandre) Vozzhennikova, 1967, (B), h.

Fig. 83 Glabridinium apatelum (Cookson and Eisenack) Brideaux, 1977, (B), h.

Fig. 84 Glossodinium dimorphum Ioannides et al., 1977, (A); a. b, dorsal, b. s, dorsal.

Fig. 85 Hystrichosphaeropsis ovum Deflandre, 1935, (B), h.

Fig. 86 Montanarocysta aemiliana Corradini, 1973, (A), h.

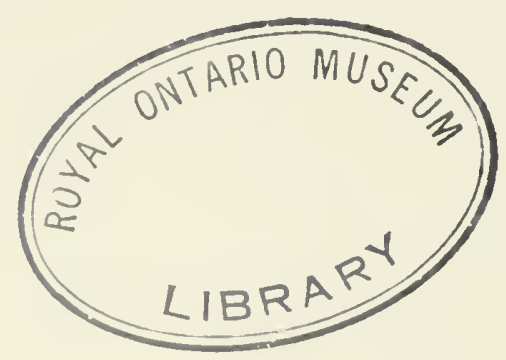



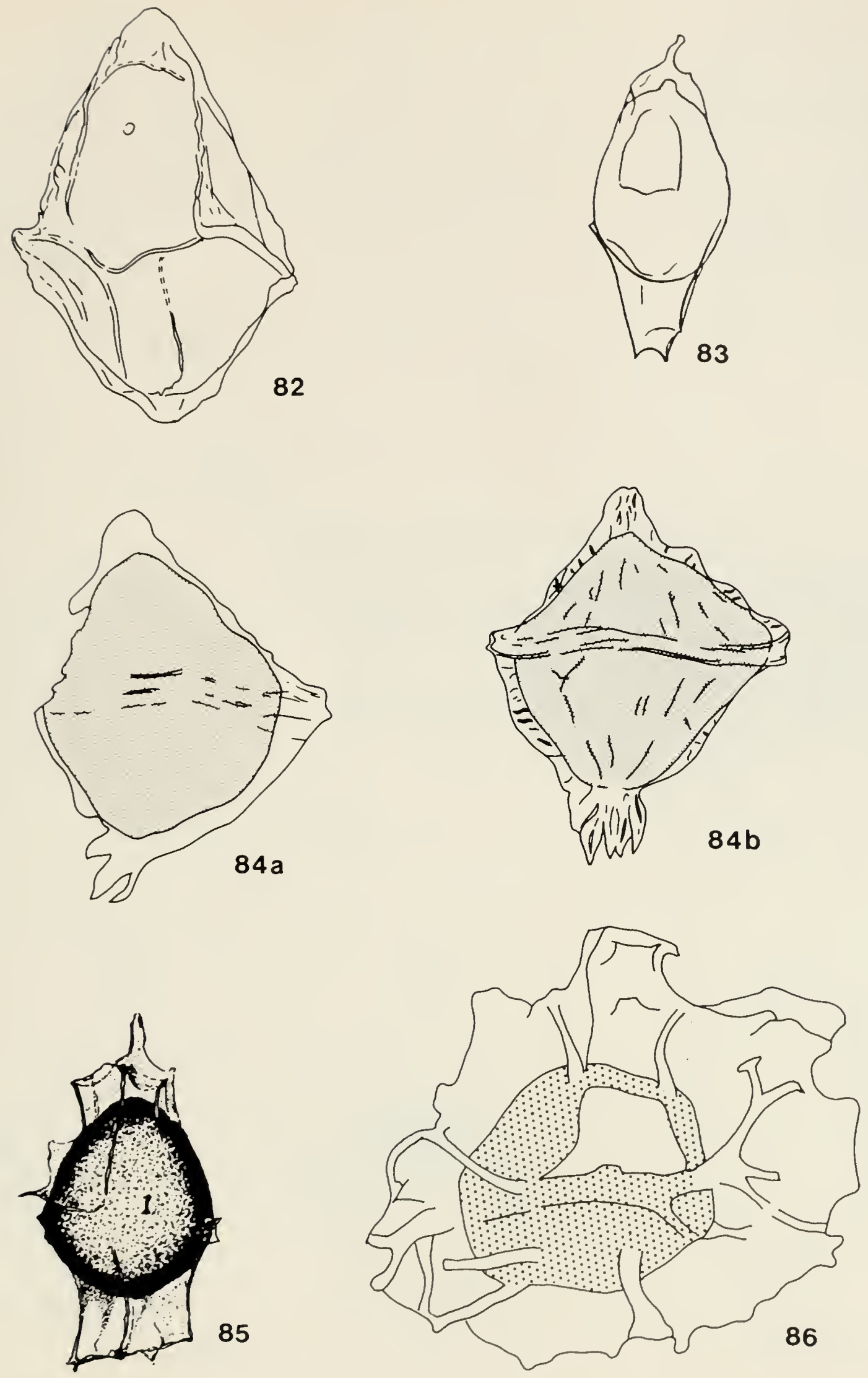


\section{Family Endoscriniaceae (cont.)}

Fig. 87 Psaligonyaulax deflandrei Sarjeant, 1966, (B), h; a. ventral, b. dorsal.

Fig. 88 Rottnestia borussica (Eisenack) Cookson and Eisenack, 1961b, (B), h.

Fig. 89 Scriniodinium crystallinum (Deflandre) Klement, 1960, (B), h.

Fig. 90 Stephodinium coronatum Deflandre, 1936, (A), h.

Fig. 91 Triblastula utinensis O. Wetzel, 1933, (B), s; a. ventral, b. dorsal.

Fig. 92 Tubotuberella rhombiformis Vozzhennikova, 1967, (B), h. 

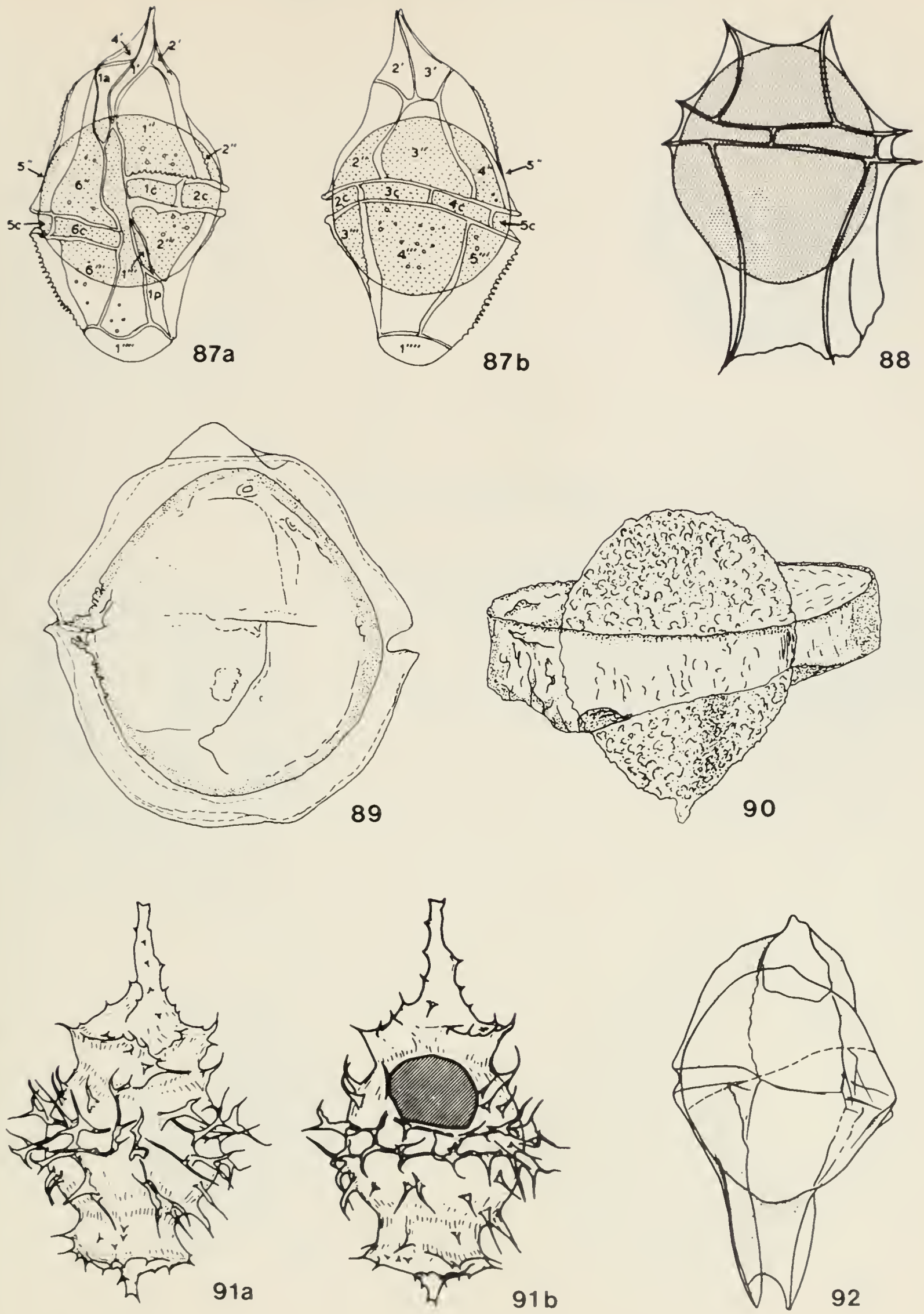


\section{Family Scriniocassiaceae (93-99)}

Fig. 93 Catillopsis abdita Drugg, 1970, (B), h.

Fig. 94 Cyclodictyon paradoxum Cookson and Eisenack, 1958, (B), h.

Fig. 95 Disphaeria macropyla Cookson and Eisenack, 1960a (B), h.

Fig. 96 Omatia montgomeryi Cookson and Eisenack, 1958, (B), h.

Fig. 97 Samlandia chlamydophora Eisenack, 1954, (B), h.

Fig. 98 Scriniocassis weberi Gocht, 1964, (B), h.

Fig. 99 Spongodinium delitiense (Ehrenberg) Deflandre, 1936, (B), h. 


\section{Scriniocassiaceae}
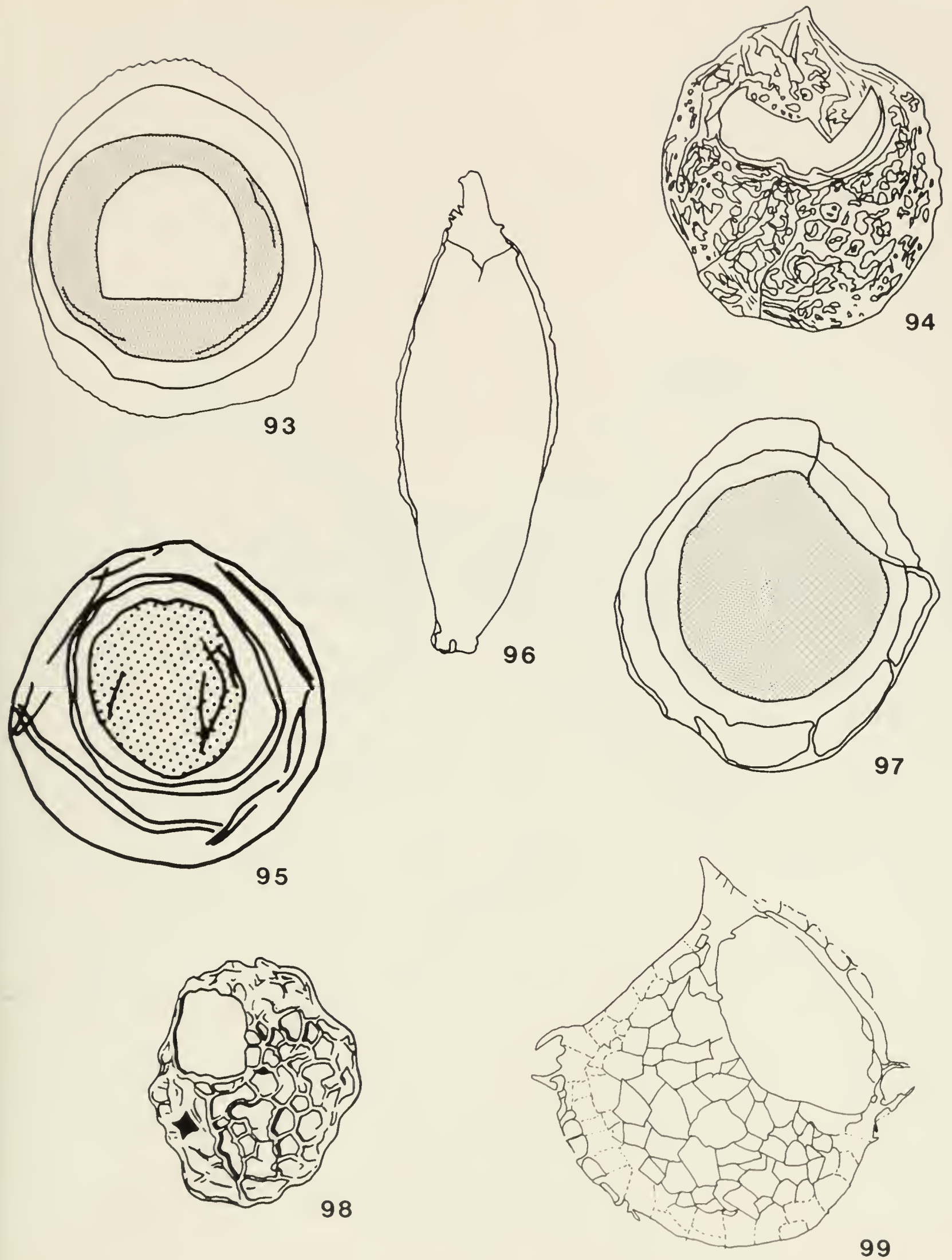


\section{Family Cordosphaeridiaceae (100-113)}

Fig. 100 Achilleodinium biformoides (Eisenack) Eaton, 1976, (B), s; a. ventral, b. dorsal.

Fig. 101 Aireiana verrucosa Cookson and Eisenack, 1965a, (B); a. h, dorsal, b. (from Stover, 1975) s; dorsal.

Fig. 102 Amphorosphaeridium fenestratum Davey, 1969b, (B), h. 


\section{Cordosphaeridiaceae}
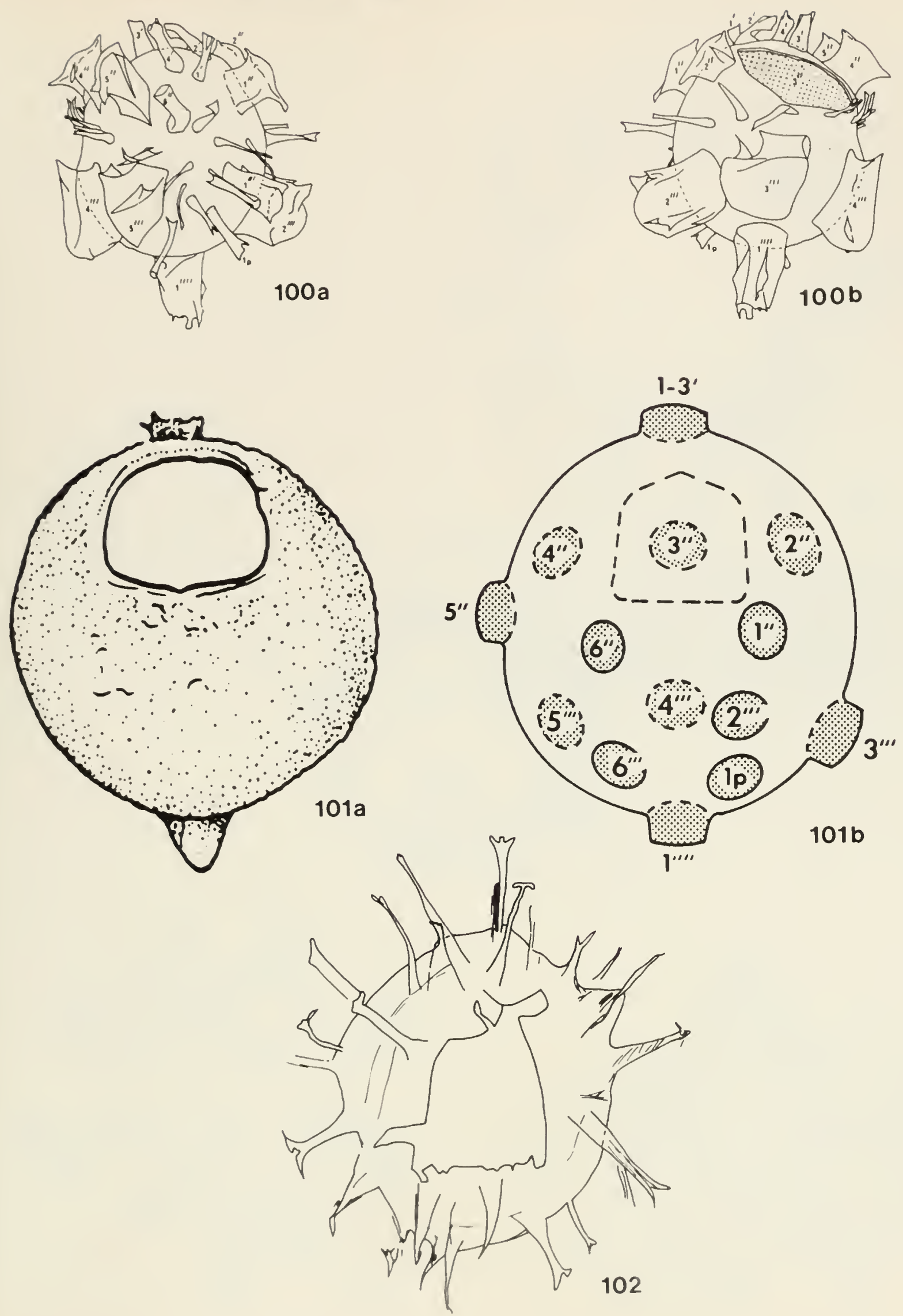
10. Family Cordosphaeridiaceae (cont.)

Fig. 103 Araneosphaera araneosa Eaton, 1976, (A), h; a. ventral, b. dorsal.

Fig. 104 Bacchidinium polypes (Cookson and Eisenack) Davey, in press, (A), h.

Fig. 105 Conosphaeridium striatoconus (Deflandre and Cookson) Cookson and Eisenack, 1969, (B), h.

Fig. 106 Cordosphaeridium inodes (Klumpp) Eisenack, 1963, (A), h.

Fig. 107 Cyclapophysis monmouthensis Benson, 1976, (B), h. 

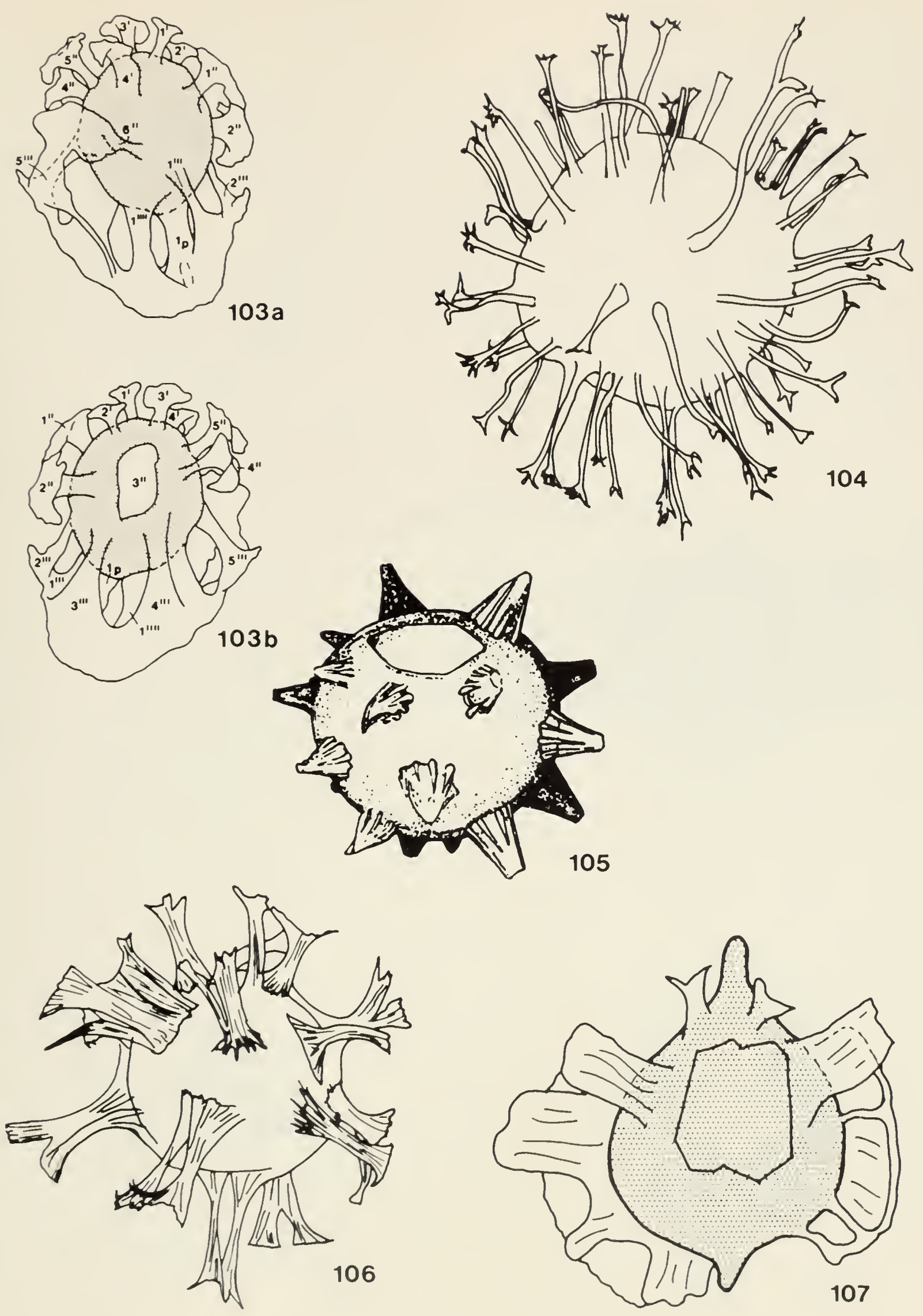
10. Family Cordosphaeridiaceae (cont.)

Fig. 108 Danea mutabilis Morgenroth, 1968, (A), h, dorsal.

Fig. 109 Kleithriasphaeridium corrugatum Davey, 1974, (B), h.

Fig. 110 Lanternosphaeridium lanosum Morgenroth, 1966, (A), h.

Fig. 111 Palmnickia lobifera Eisenack, 1954, (A), h.

Fig. 112 Silicisphaera ferox (Deflandre) Davey and Verdier, 1976, (B), s.

Fig. 113 Turbiosphaera filosa (Wilson) Archangelsky, 1969, (A), h. 

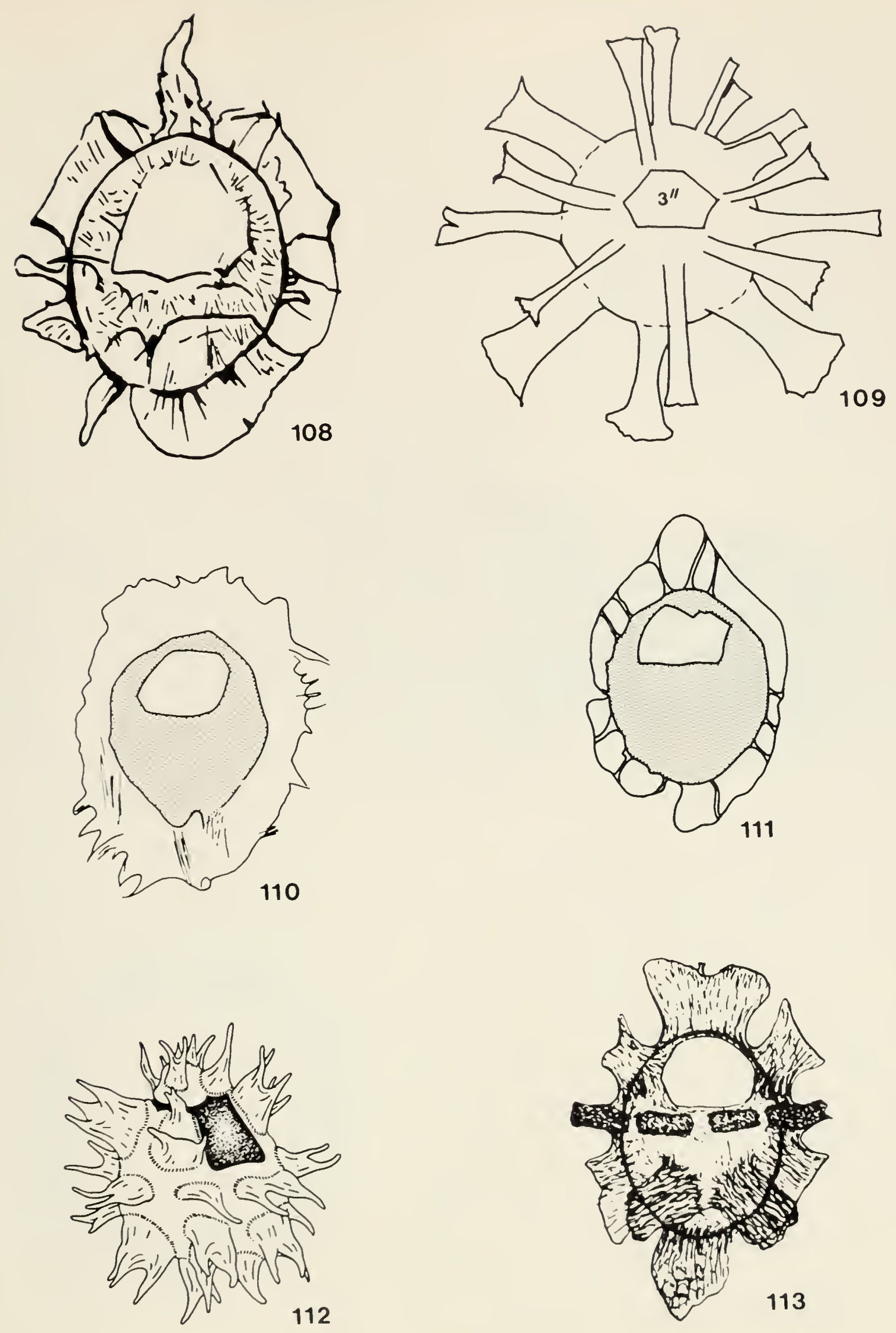
11. Family Lingulodiniaceae (114-120)

Fig. 114 Coronifera oceanica Cookson and Eisenack, 1958, (B), h.

Fig. 115 Exochosphaeridium phragmites Davey et al., 1966, (B), h.

Fig. 116 Lingulodinium machaerophorum (Deflandre and Cookson) Wall, 1967, (B), h.

Fig. 117 Nexosispinum hesperum Davey, in press, (B), h.

Fig. 118 Operculodinium centrocarpum (Deflandre and Cookson) Wall, 1967, (B), s.

Fig. 119 Protoellipsodinium spinocristatum Davey and Verdier, 1971, (C), h.

Fig. 120 Trioperculodinium siculum Drugg, 1970, (B), h. 


\section{Lingulodiniaceae}
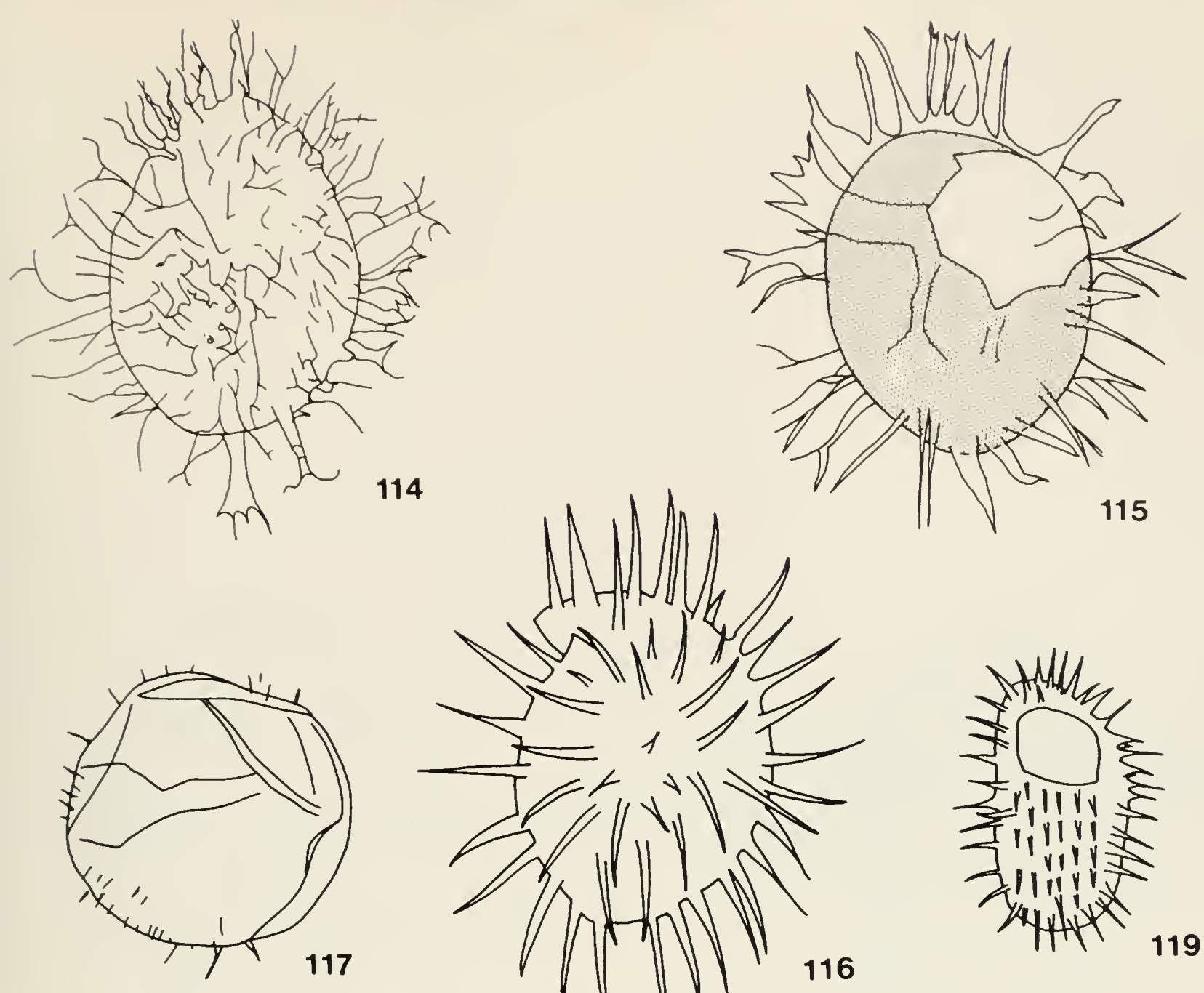

114

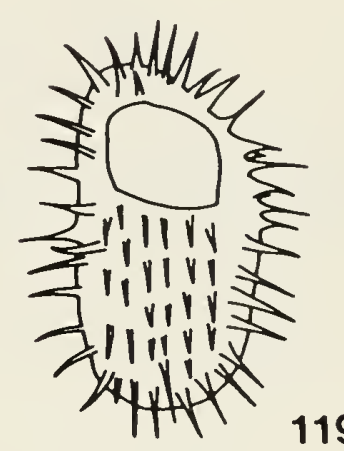

116

119
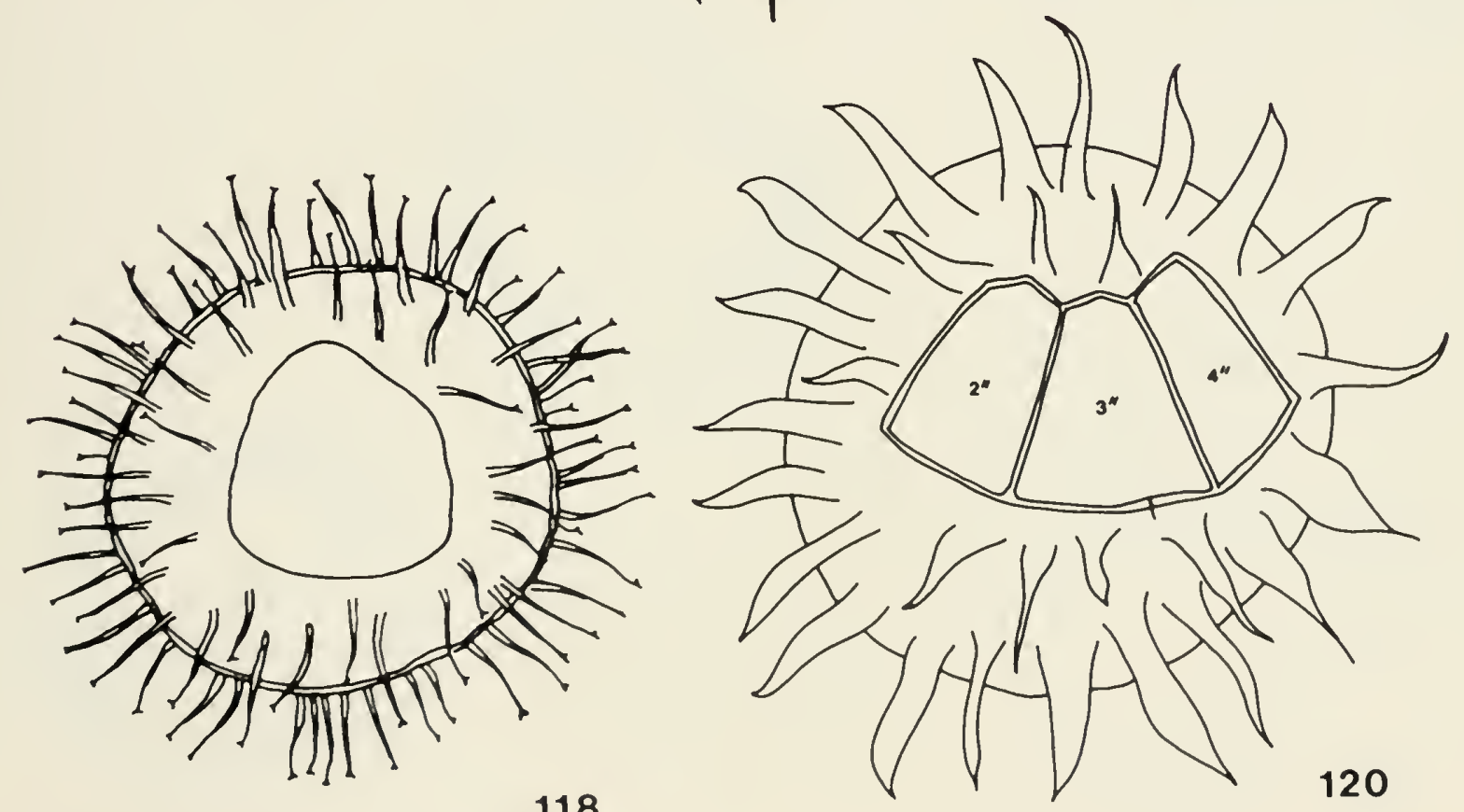


\section{Family Ctenidodiniaceae (121-129)}

Fig. 121 Biorbifera johnewingii Habib, 1972, (C), h.

Fig. 122 Breedoxella caperata (Brideaux) Norris, 1978b, (B), h.

Fig. 123 Cauca parva (Alberti) Davey and Verdier, 1971, (C), h.

Fig. 124 Ctenidodinium ornatum (Eisenack) Deflandre, 1938, (B), s; a. ventral, b. dorsal.

Fig. 125 Dichadogonyaulax culmula (Norris) Loeblich and Loeblich, 1968, (B), h; a. oblique ventral, b. dorsal.

Fig. 126 Energlynia kyrbasia Sarjeant, 1976, (C), h. 


\section{Ctenidodiniaceae}
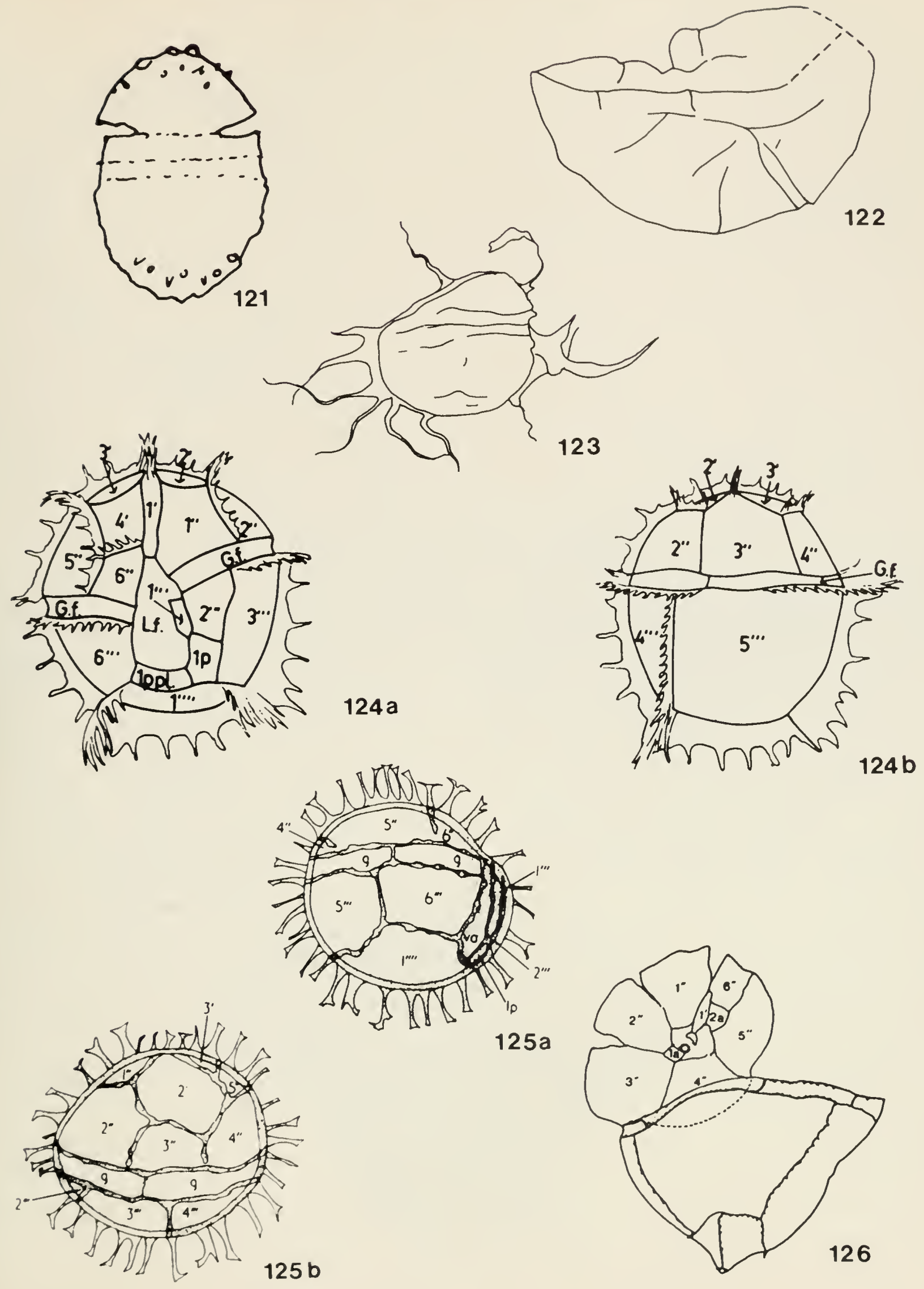


\section{Family Ctenidodiniaceae (cont.)}

Fig. 127 Eodinia pachytheca Eisenack, 1936, (B), a. h, b. s, dorsal, c. s, ventral.

Fig. 128 Toolongia medusoides Cookson and Eisenack, 1960a, (B), h.

Fig. 129 Wanaea spectabilis (Deflandre and Cookson) Cookson and Eisenack, 1958, (B), p 


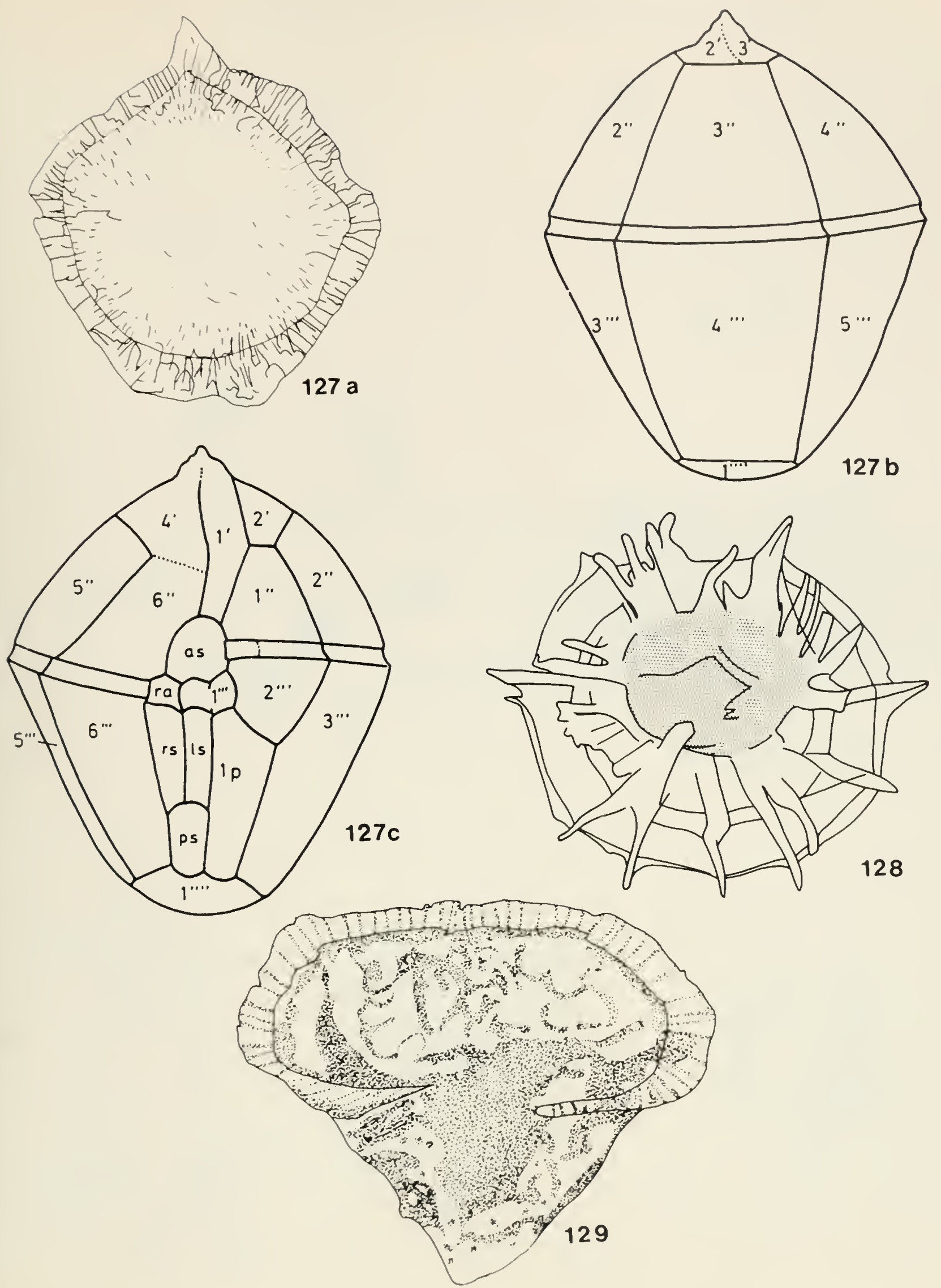


13. Family Hystrichosphaeridiaceae (130-152)

Fig. 130 Adnatosphaeridium vittatum Williams and Downie, 1966b, (B), h.

Fig. 131 Amphorula metaelliptica Dodekova, 1969, (B), h; a. ventral, b. dorsal.

Fig. 132 Areosphaeridium diktyoplokus (Klumpp) Eaton, 1971, (A), h.

Fig. 133 Bourkidinium granulatum Morgan, 1975, (B), h.

Fig. 134 Compositosphaeridium costatum (Davey and Williams) Dodekova, 1974, (B), s.

Fig. 135 Diphyes colligerum (Deflandre and Cookson) Cookson, 1965, (B), h. 


\section{Hystrichosphaeridiaceae}
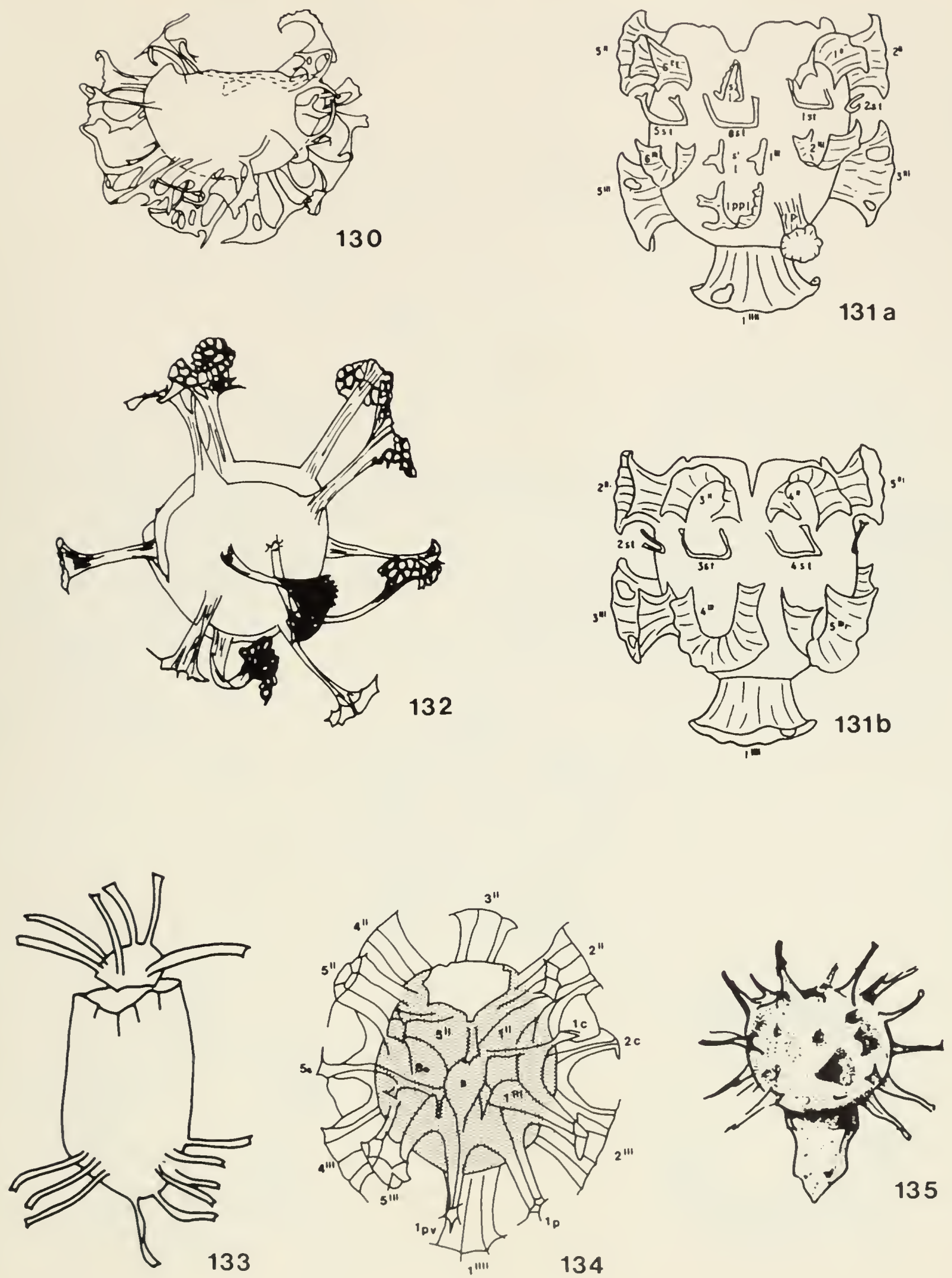


\section{Family Hystrichosphaeridiaceae (cont.)}

Fig. 136 Discorsia nanna (Davey) Duxbury, 1977, (C), s; a. ventral, b. dorsal.

Fig. 137 Distatodinium craterum Eaton, 1976, (B), h.

Fig. 138 Emmetrocysta urnaformis (Cookson) Stover, 1975, (B), s; a. antapical, b. apical.

Fig. 139 Epiplosphaera bireticulata Klement, 1960, (B), h.

Fig. 140 Hemiplacophora semilunifera Cookson and Eisenack, 1965a, (B), h. 

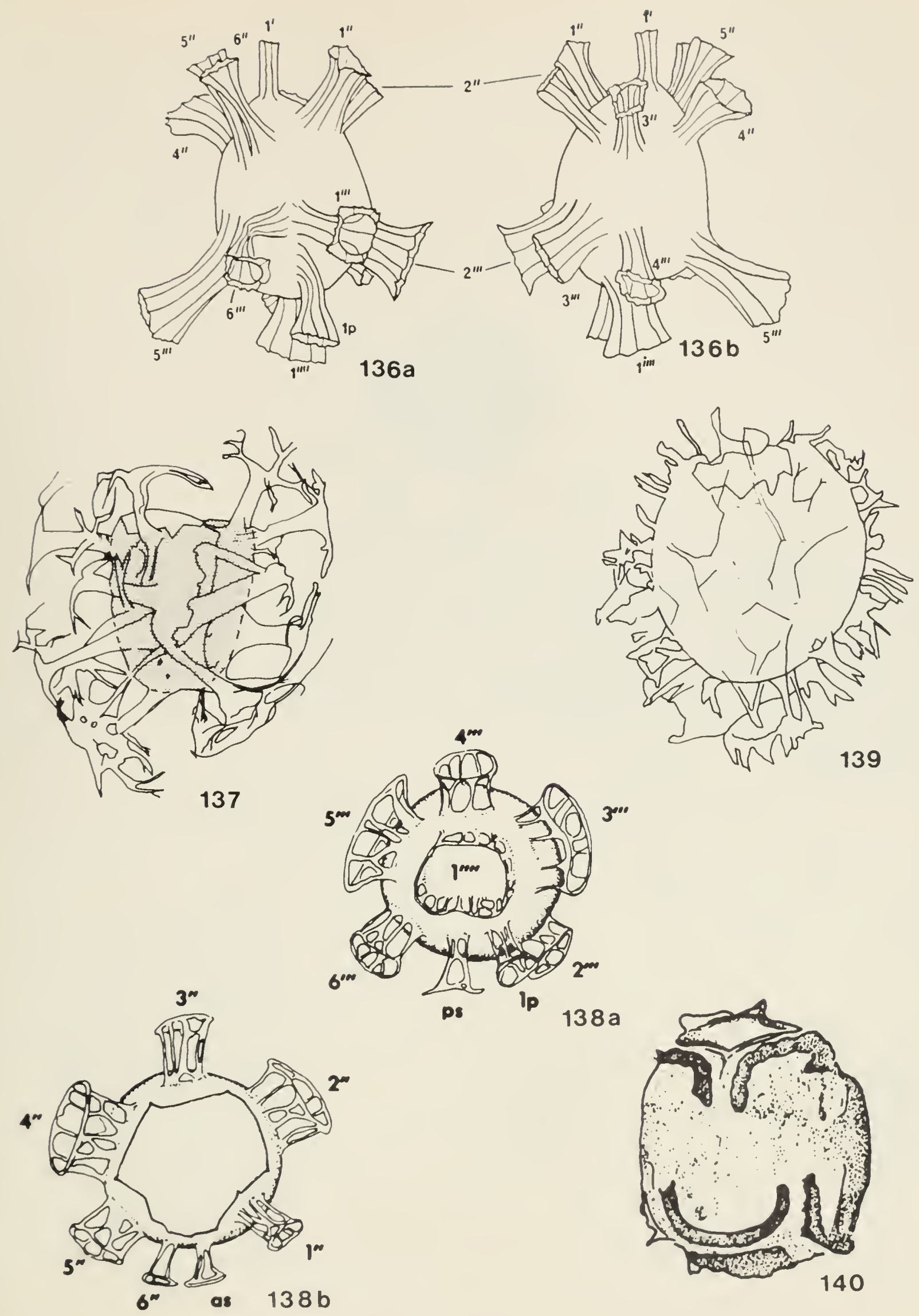
13. Family Hystrichosphaeridiaceae (cont.)

Fig. 141 Hystrichokolpoma cinctum Klumpp, 1953, (B), s; a. ventral, b. dorsal.

Fig. 142 Hystrichosphaeridium tubiferum (Ehrenberg) Deflandre, 1937, (B), s.

Fig. 143 Litosphaeridium siphoniphorum (Cookson and Eisenack) Davey and Williams, 1966, (B), h.

Fig. 144 Oligosphaeridium complex (White) Davey and Williams, 1966, (A), s.

Fig. 145 Peridictyocysta mirabilis (Cookson and Eisenack) Cookson and Eisenack, 1974, (B), h.

Fig. 146 Perisseiasphaeridium pannosum Davey and Williams, 1966, (B), s. 

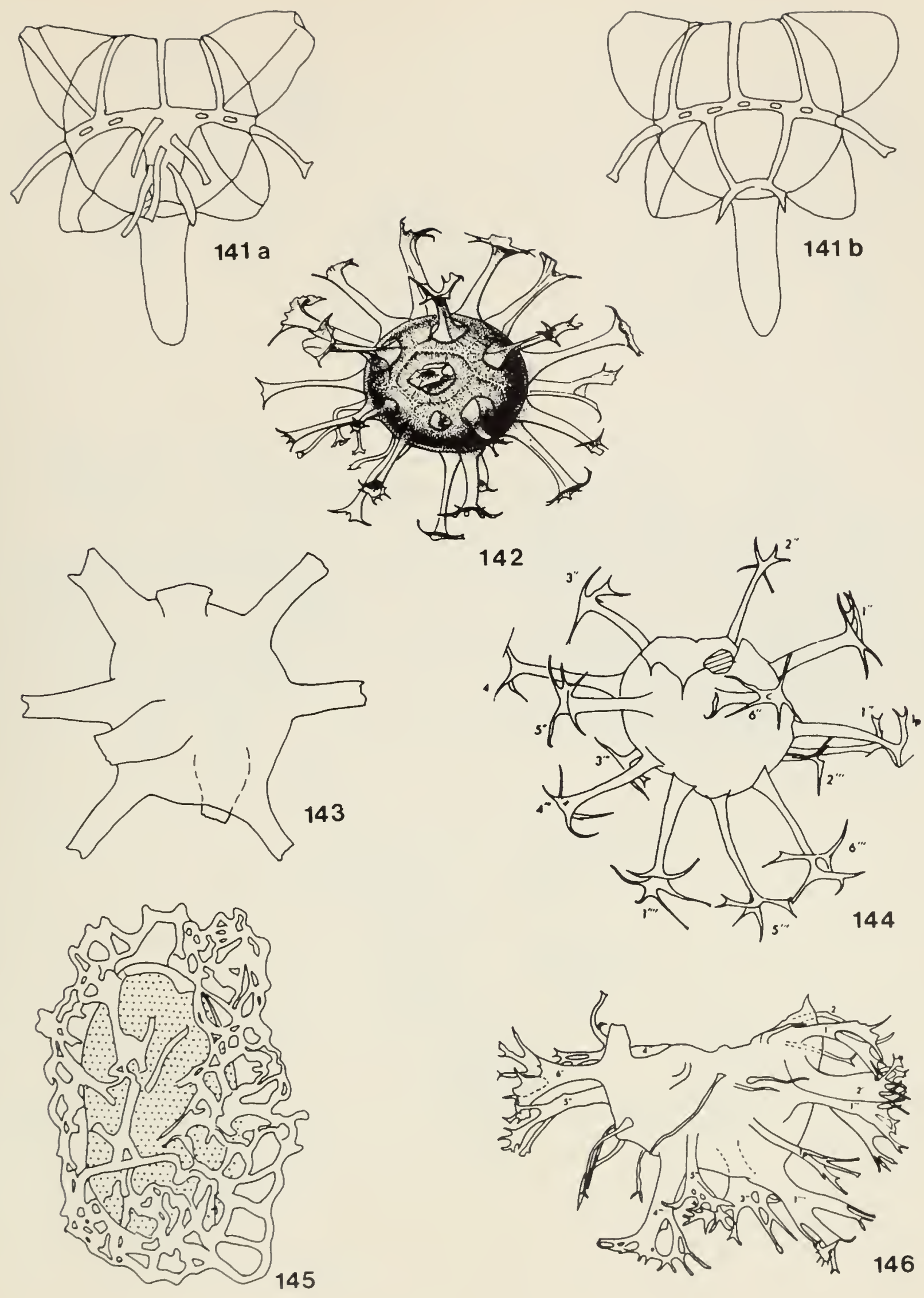


\section{Family Hystrichosphaeridiaceae (cont.)}

Fig. 147 Polystephanephorus calathus (Sarjeant) Downie and Sarjeant, 1965, (B), h.

Fig. 148 Prolixosphaeridium parvispinum (Deflandre) Davey et al., 1969, (C), h. (Refer to Davey and Verdier, 1974, pp. 636-7 for a discussion of the synonomy of the originally designated type species $P$. deirense with $P$ parvispinum.)

Fig. 149 Surculosphaeridium cribrotubiferum (Sarjeant) Davey et al., 1966, (B), s; a. oblique ventral, b. dorsal.

Fig. 150 Sistematophora areolata Klement, 1960, (B), h; a. dorsal, b. ventral.

Fig. 151 Taeniophora iunctispina Klement, 1960, (A), h.

Fig. 152 Tanyosphaeridium variecalamum Davey and Williams, 1966, (B), h. 


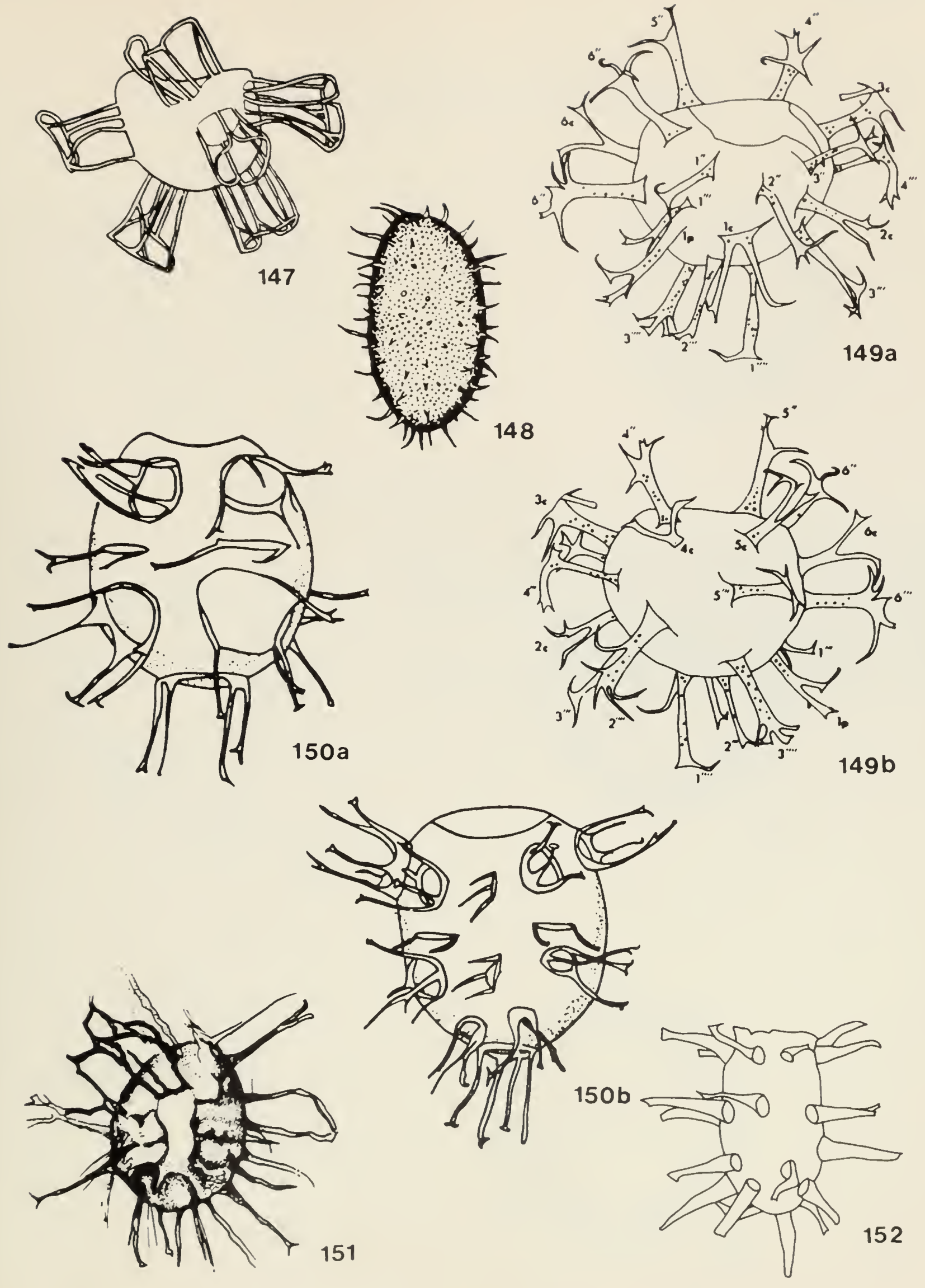


14. Family Cleistosphaeridiaceae (153-158)

Fig. 153 Cleistosphaeridium diversispinosum Davey et al., 1966, (B), h.

Fig. 154 Cobricosphaeridium hebes Harland and Sarjeant, 1970, (B), h.

Fig. 155 Impletosphaeridium transfodum Morgenroth, 1966, (C), h.

Fig. 156 Kallosphaeridium brevibarbatum De Coninck, 1969, (B), h.

Fig. 157 Lingulasphaera spinula Drugg, 1970, (B), h.

Fig. 158 Polysphaeridium subtile Davey and Williams, 1966, (B), h. 


\section{Cleistosphaeridiaceae}
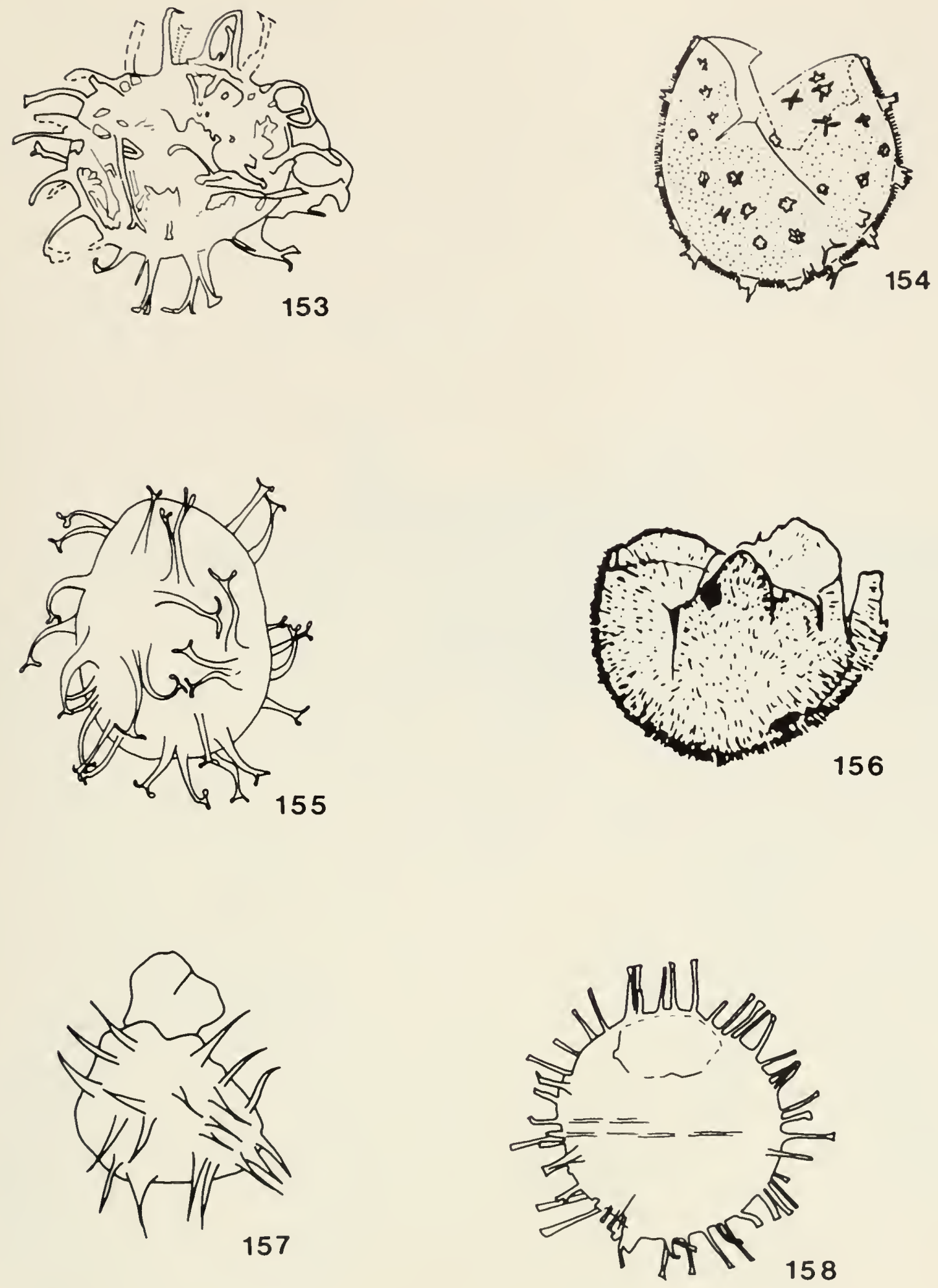
15. Family Florentiniaceae (159-163)

Fig. 159 Callaiosphaeridium asymmetricum (Deflandre and Courteville) Davey and Williams, 1966, (B), h. Fig. 160 Eocladopyxis peniculata Morgenroth, 1966, (C), h.

Fig. 161 Florentinia laciniata Davey and Verdier, 1973, (B), h.

Fig. 162 Hemicystodinium zoharyi (Rossignol) Wall, 1967, (C), h.

Fig. 163 Homotryblium tenuispinosum Davey and Williams, 1966, (B), h. 


\section{Florentiniaceae}
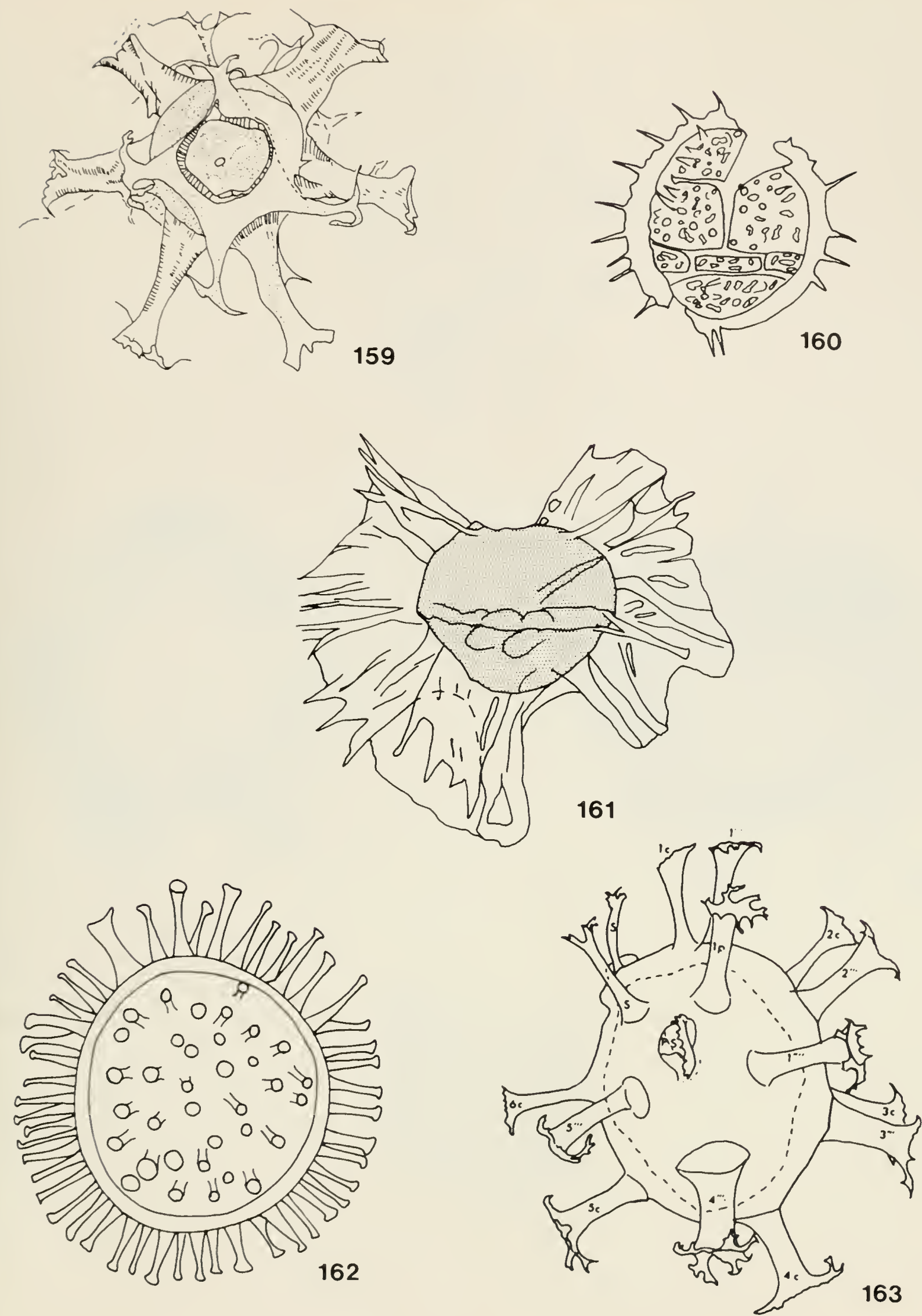
16. Family Areoligeraceae (164-166)

Fig. 164 Areoligera senonensis Lejeune-Carpentier, 1938, (A), s.

Fig. 165 Chiropteridium lobospinosum (Gocht) Gocht, 1960, (A), h; a. dorsal, b. ventral.

Fig. 166 Cyclonephelium compactum Deflandre and Cookson, 1955, (B), h. 


\section{Areoligeraceae}
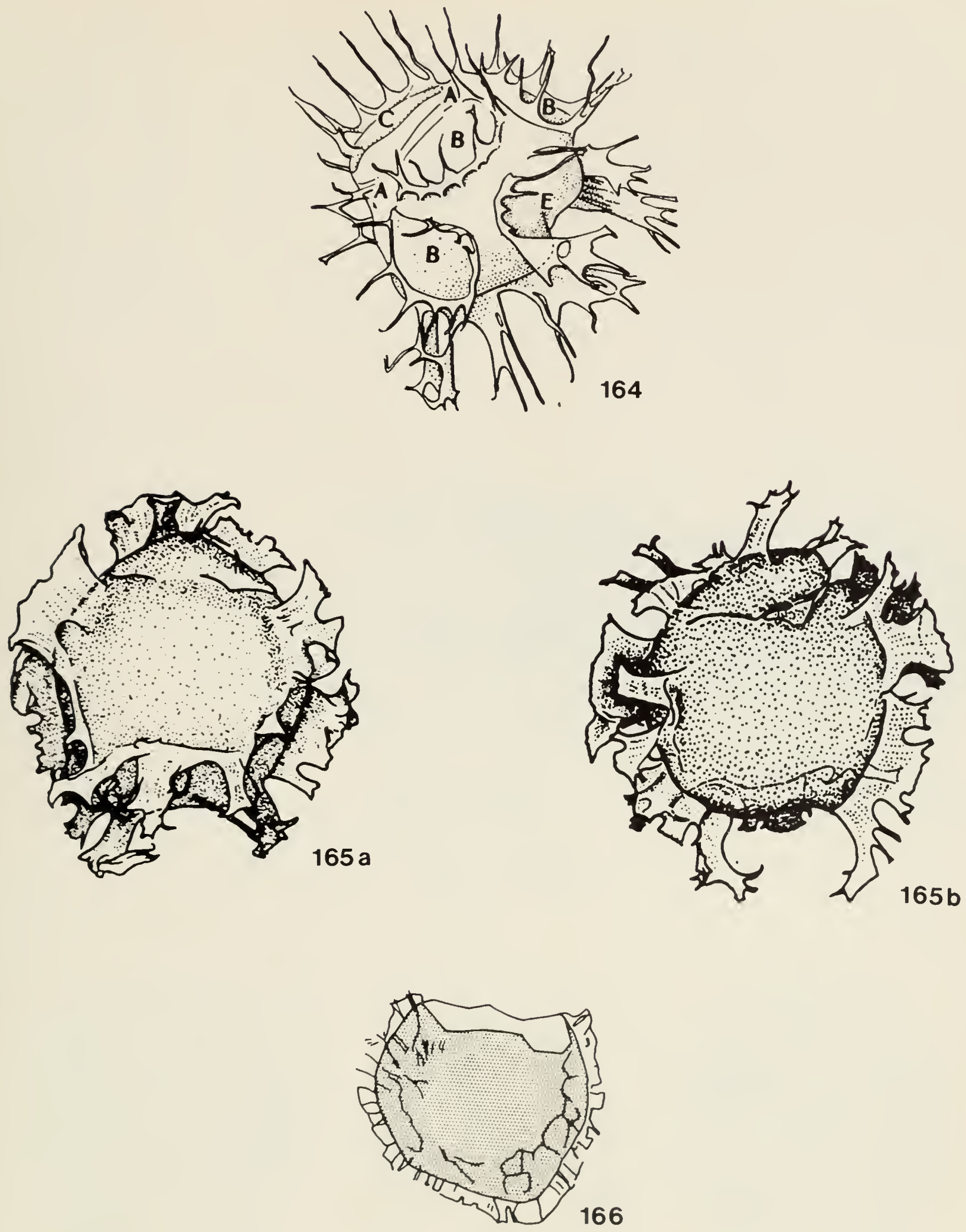
17. Family Lithodiniaceae (167-181)

Fig. 167 Belodinium dysculum Cookson and Eisenack, 1960b, (A), h.

Fig. 168 Canninginopsis denticulata Cookson and Eisenack, 1962b, (B), h; a. ventral, b. dorsal.

Fig. 169 Clathroctenocystis elegans Wiggins, 1972, (A), s; a. ventral, b. dorsal.

Fig. 170 Eisenackia crassitabulata Deflandre and Cookson, 1955, (B), h; a. oblique dorsal, b. oblique ventral.

Fig. 171 Ellipsoidictyum cinctum Klement, 1960, (B), h; a. dorsal, b. ventral. 
17. Lithodiniaceae
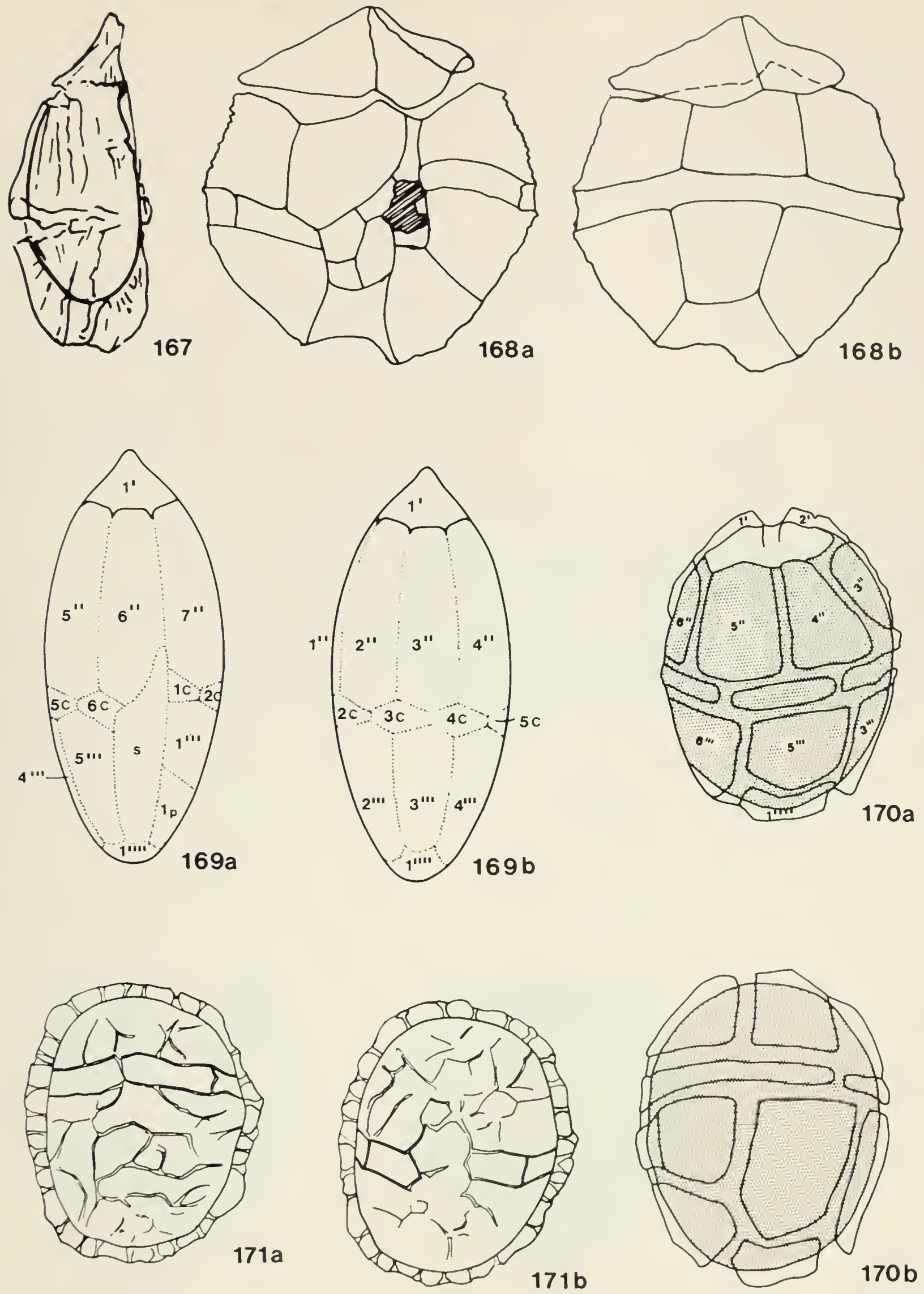


\section{Family Lithodiniaceae (cont.)}

Fig. 172 Fibradinium annetorpense Morgenroth, 1968, (C), s; a. ventral, b. dorsal.

Fig. 173 Gillinia hymenophora Cookson and Eisenack, 1960a, (C), h.

Fig. 174 Glyphanodinium facelum Drugg, 1964, (C), s; a. ventral, b. dorsal.

Fig. 175 Histiocysta palla Davey, 1969a, (C), h; a. ventral, b. dorsal.

Fig. 176 Histiophora ornata Klement, 1960, (B), h; a. dorsal, b. ventral.

Fig. 177 Horologinella lineata Cookson and Eisenack, 1962a, (C), h; a. dorsal, b. ventral.

Fig. 178 Lanterna bulgarica Dodekova, 1969, (B), h; a. ventral, b. dorsal. 

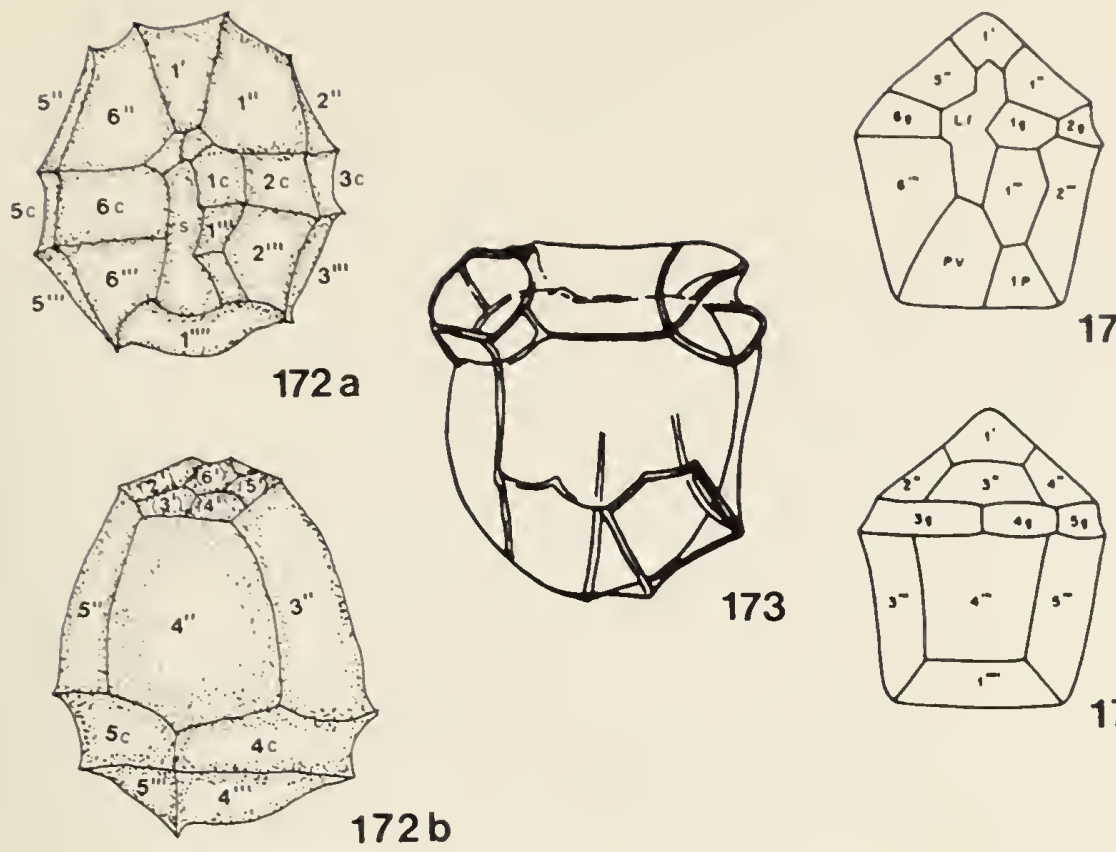

$174 a$

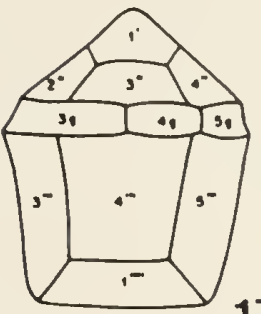

$174 b$
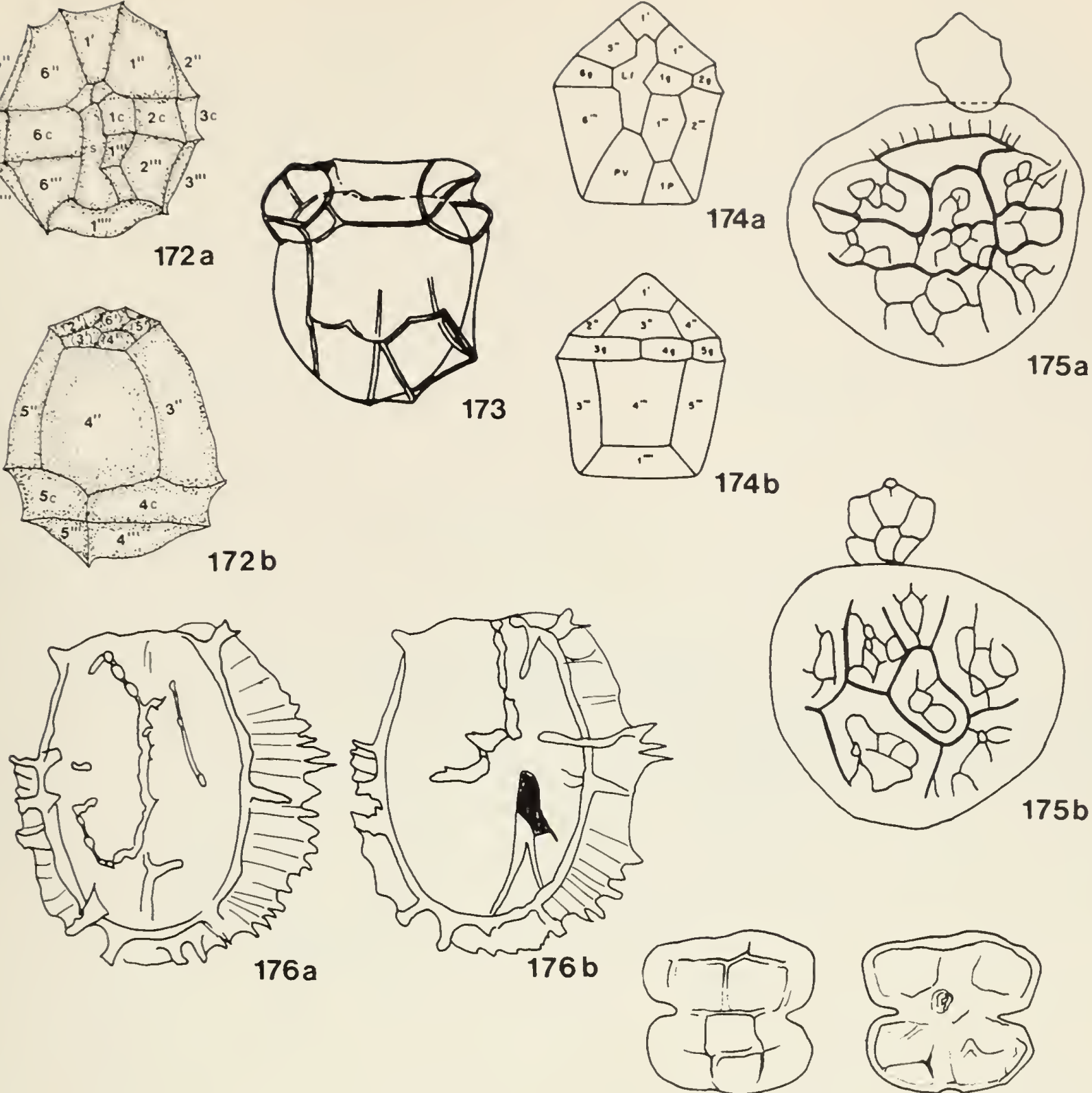

$177 a$

$177 \mathrm{~b}$
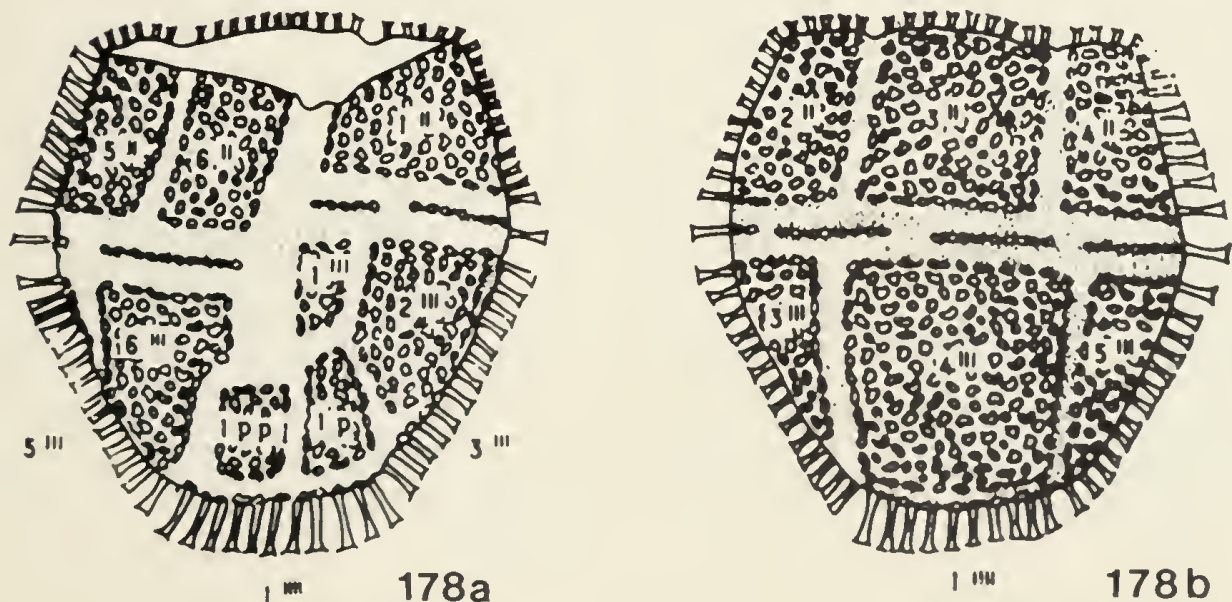

$175 b$ 
17. Family Lithodiniaceae (cont.)

Fig. 179 Lithodinia jurassica Eisenack, 1935, (B), h; a. ventral, b. dorsal.

Fig. 180 Parvulodinium clavatum Dodekova, 1975, (C), h; a. ventral, b. dorsal.

Fig. 181 Schematophora speciosa Deflandre and Cookson, 1955, (B), h; a. dorsal, b. ventral. 

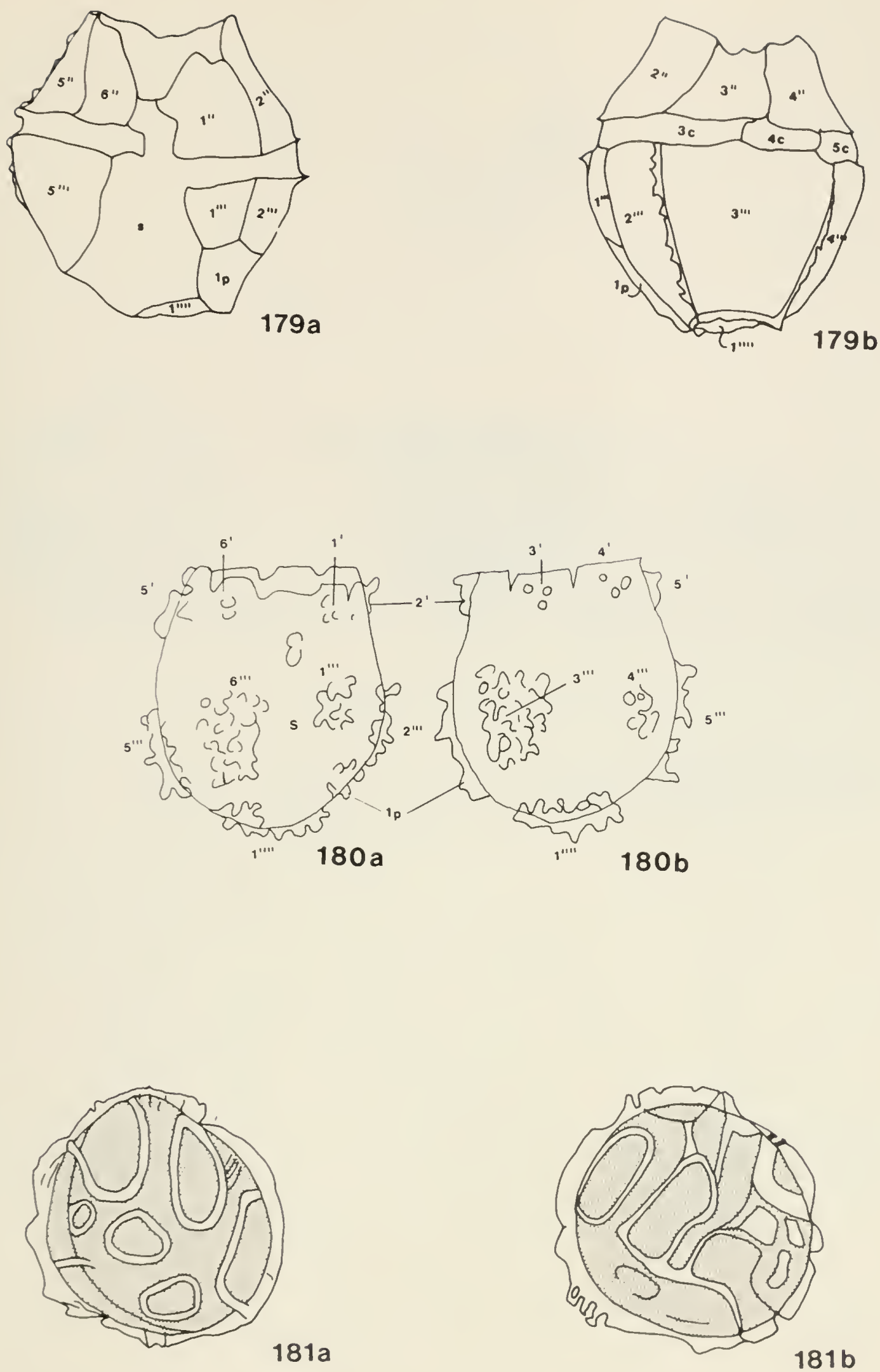
18. Family Batiacasphaeraceae (182-187)

Fig. 182 Batiacasphaera compta Drugg, 1970, (B), h.

Fig. 183 Cassiculosphaeridia reticulata Davey, 1969a, (C), h.

Fig. 184 Cassidium fragile (Harris) Drugg, 1967, (B), h.

Fig. 185 Epelidosphaeridia spinosa (Cookson and Hughes) Davey, 1969a, (B), h.

Fig. 186 Membranosphaera maastrichtica Samoilovitch ex Norris and Sarjeant, 1965, (C), s.

Fig. 187 Rhombodella natans Cookson and Eisenack, 1962b, (B), h.

\section{Family Xiphophoridiaceae (188-190)}

Fig. 188 Dorocysta litotes Davey, 1970, (C), h.

Fig. 189 Raphidodinium fucatum Deflandre, 1936, (B), h. 
182-189

18. Batiacasphaeraceae
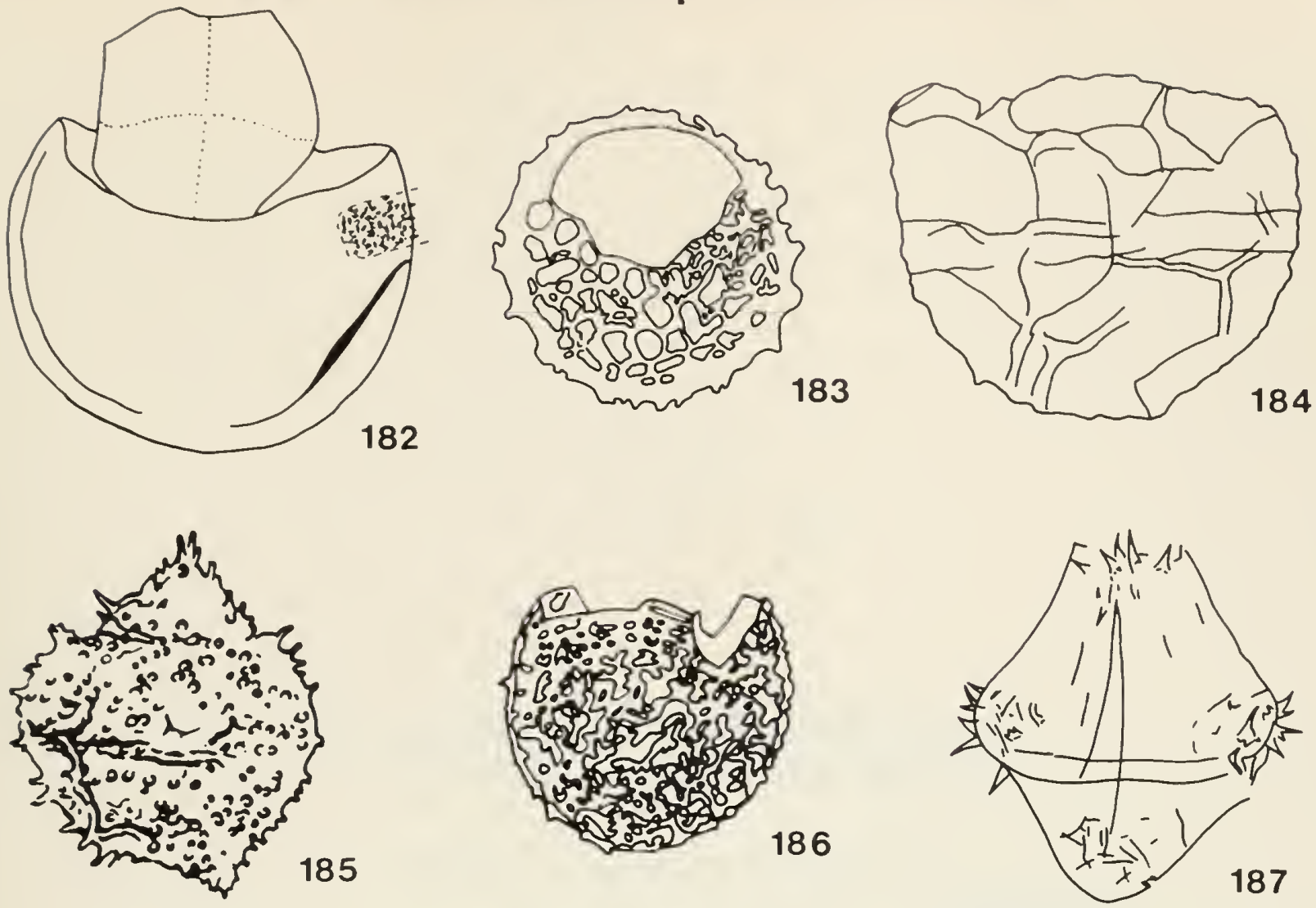

19. Xiphophoridiaceae
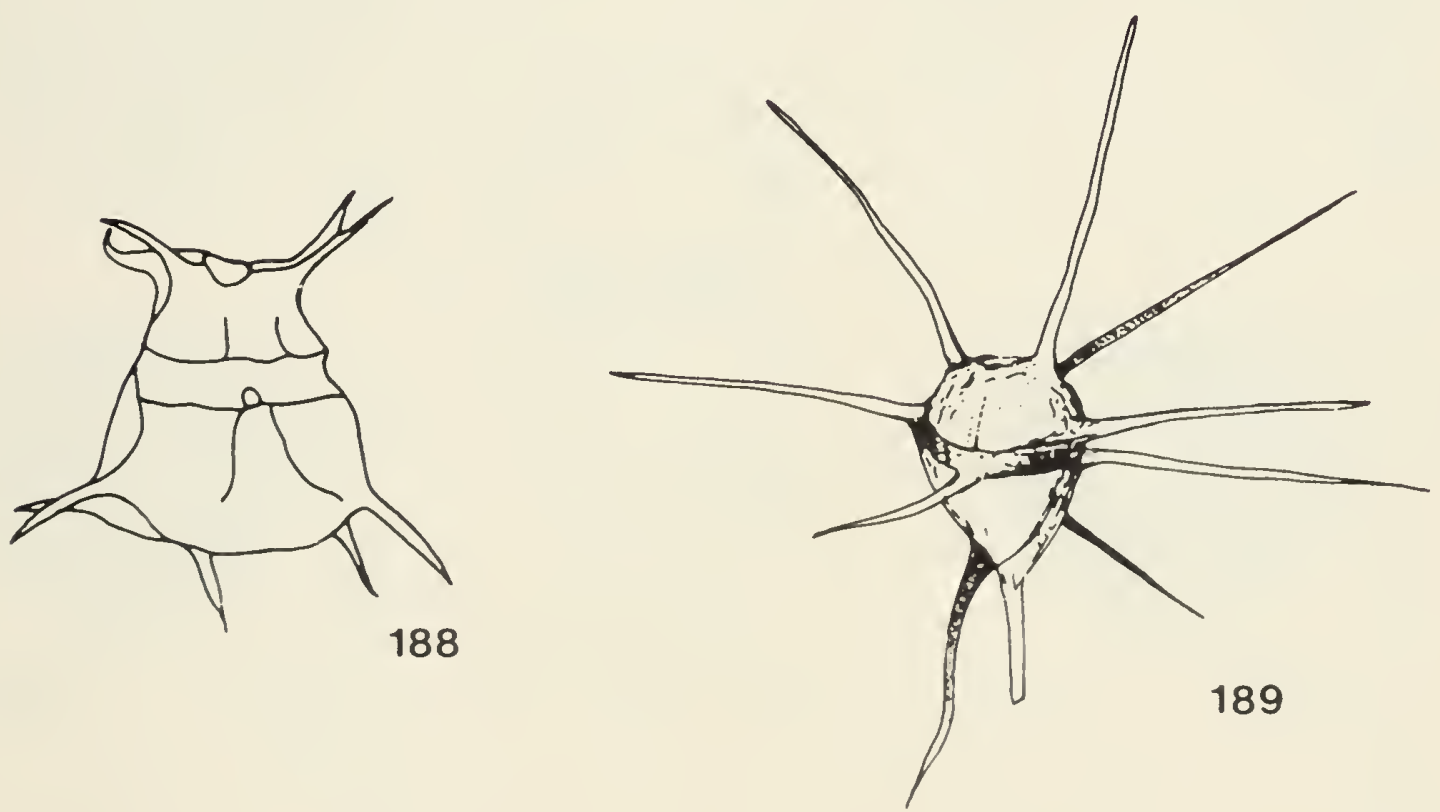
19. Family Xiphophoridiaceae (cont.)

Fig. 190 Xiphophoridium alatum (Cookson and Eisenack) Sarjeant, 1966, (A), h.

20. Family Senoniasphaeraceae (191-199)

Fig. 191 Dingodinium jurassicum Cookson and Eisenack, 1958, (B), h.

Fig. 192 Duosphaeridium nudum (Cookson) Loeblich and Loeblich, 1968, (B), h.

Fig. 193 Palynodinium grallator Gocht, 1970a, (A), s; a. apical, b. ventral, c. dorsal. 


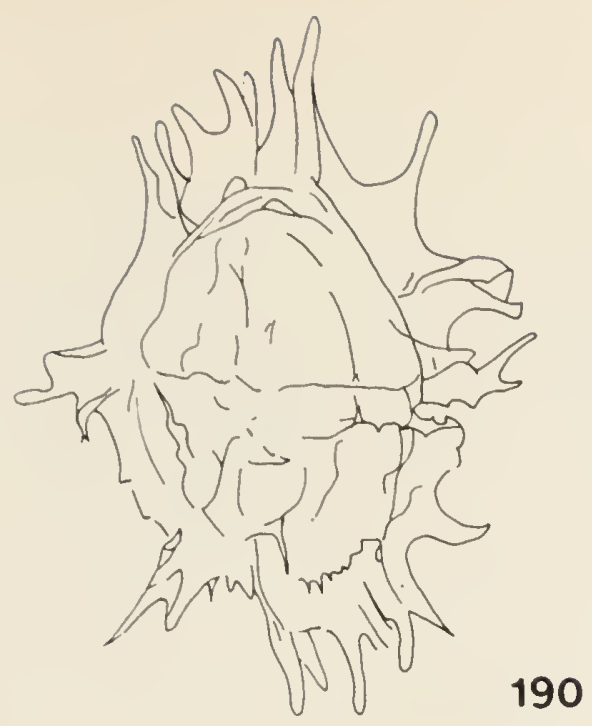

\section{Senoniasphaeraceae}
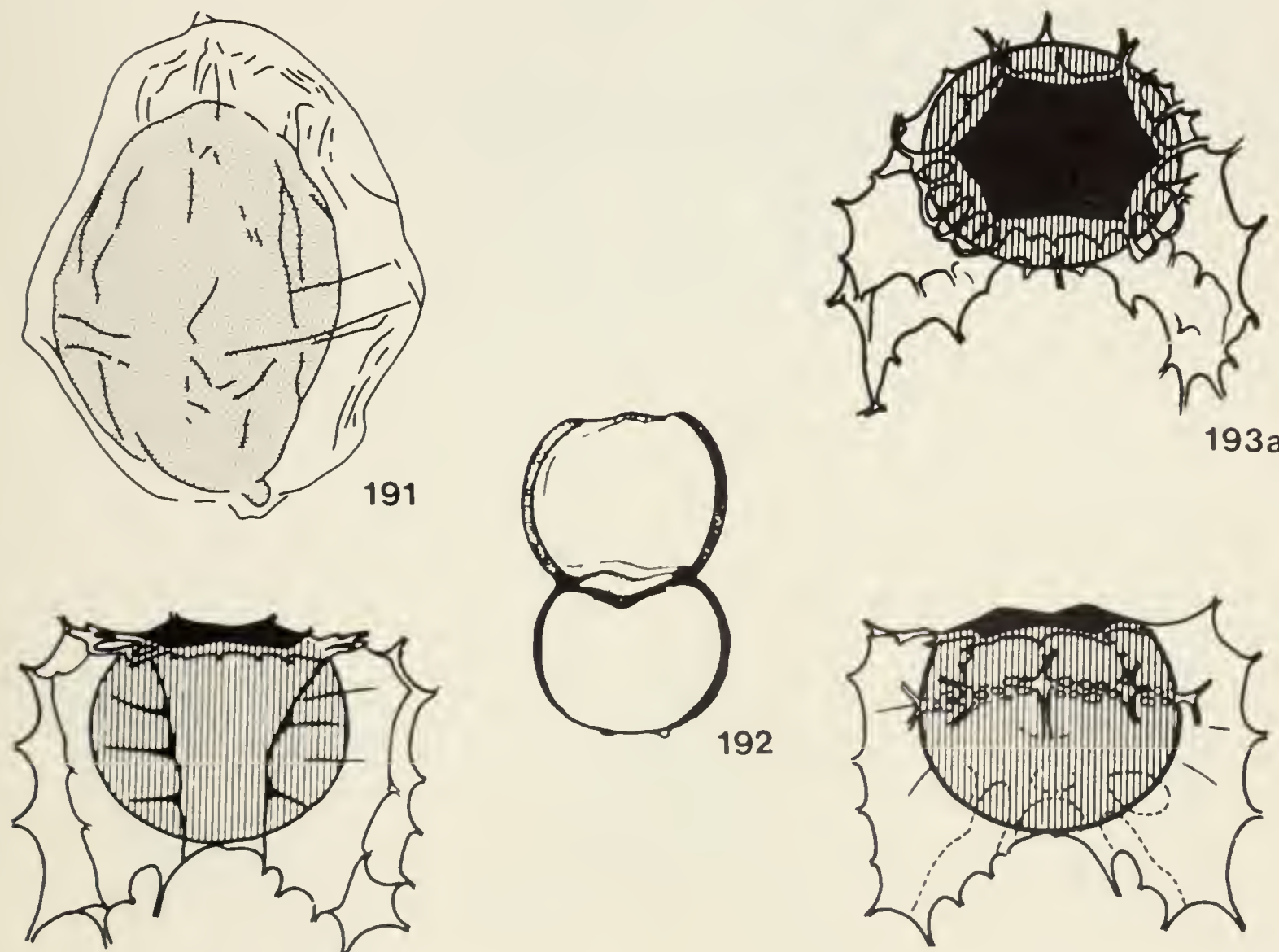


\section{Family Senoniasphaeraceae (cont.)}

Fig. 194 Parvocavatus tuberosus Gitmez, 1970, (B), h; a. ventral, b. dorsal.

Fig. 195 Polygonifera evitti Habib, 1972, (C), h.

Fig. 196 Senoniasphaera protrusa Clarke and Verdier, 1967, (B), s.

Fig. 197 Sirmiodinium grossii Alberti, 1961, (B), h.

Fig. 198 Trigonopyxidia ginella (Cookson and Eisenack) Downie and Sarjeant, 1965, (B), h.

Fig. 199 Wallodinium glaessneri (Cookson and Eisenack) Leoblich and Loeblich, 1968, (A), h. 

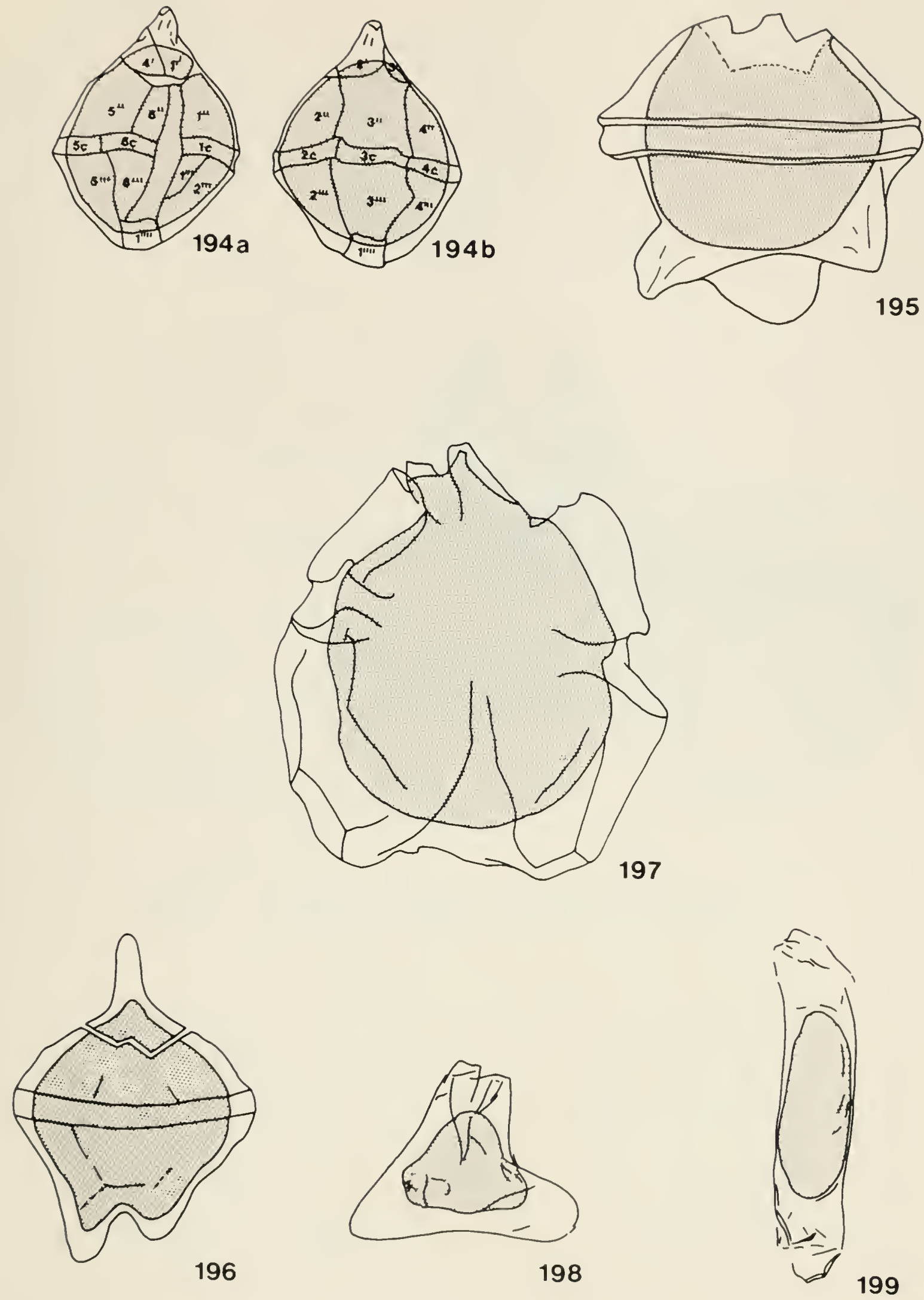
21. Family Membranilarnaciaceae (200-204)

Fig. 200 Chlamydophorella nyei Cookson and Eisenack, 1958, (C), h.

Fig. 201 Gardodinium trabeculosum (Gocht) Alberti, 1961, (B), h.

Fig. 202 Membranilarnacia leptoderma (Cookson and Eisenack) Eisenack, 1963, (B), h.

Fig. 203 Renidinium membraniferum Morgenroth, 1968, (B), h.

Fig. 204 Valensiella ovula (Deflandre) Eisenack, 1963, (B), h; a. ventral, b. dorsal.

\section{Family Stephanelytraceae (205)}

Fig. 205 Stephanelytron redcliffense Sarjeant, 1961a, (C), s; a. dorsal, b. ventral. 


\section{Membranilarnaciaceae}
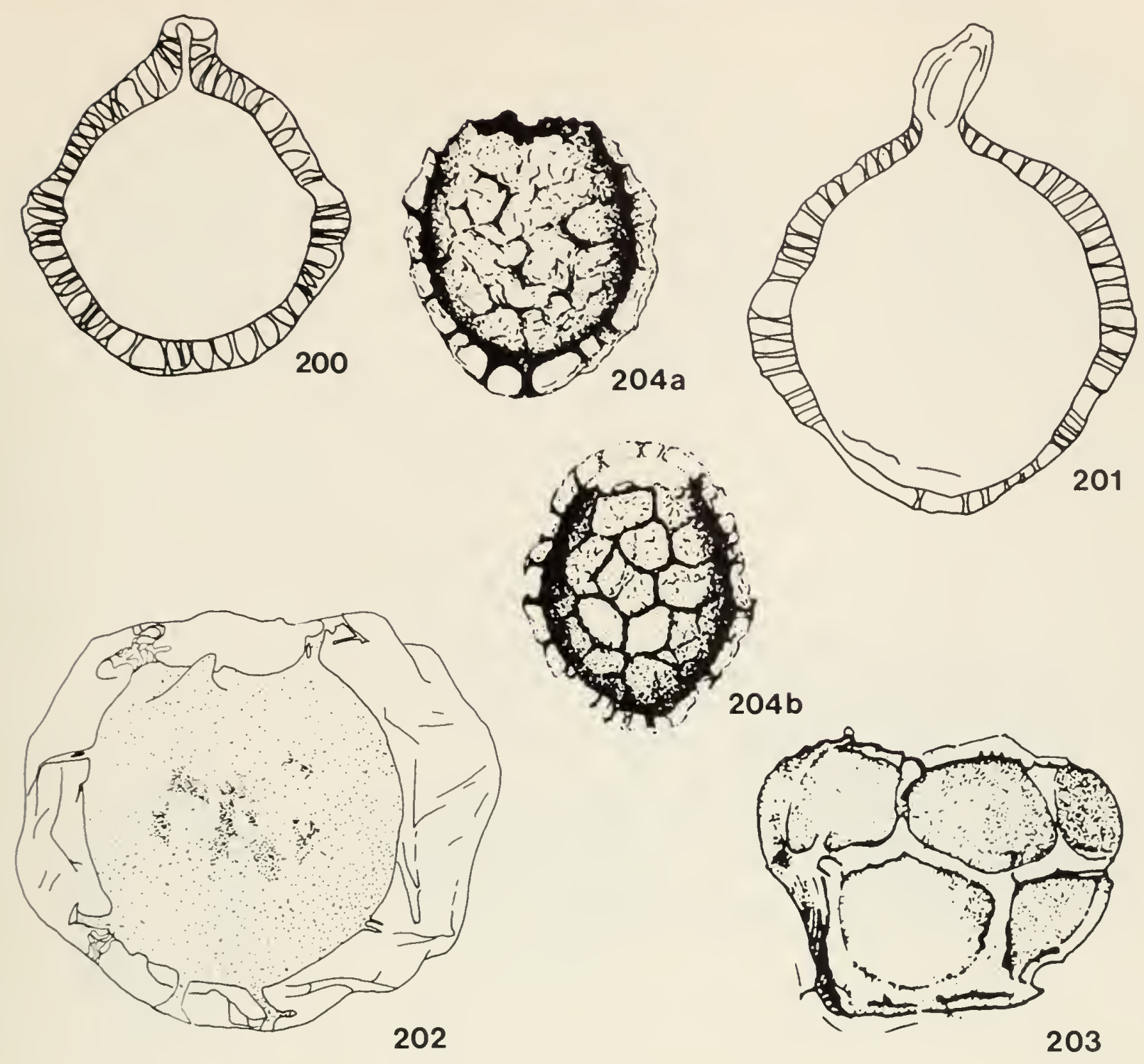

22. Stephanelytraceae
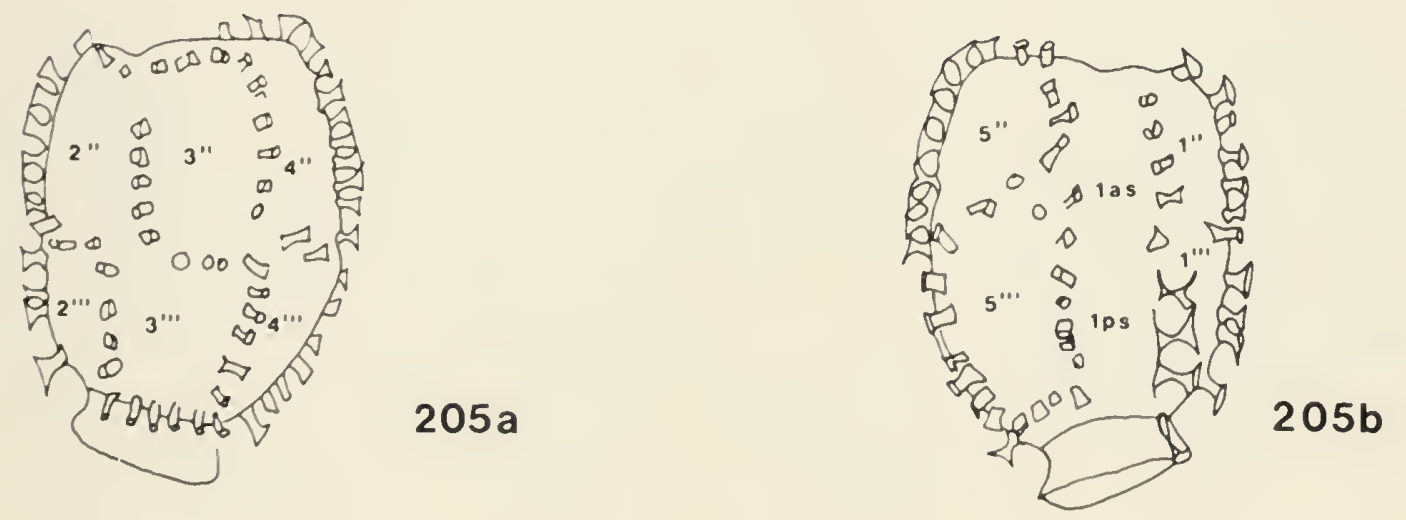
23. Family Deflandreaceae (206-225)

Fig. 206 Alterbia recticornis (Vozzhennikova) Lentin and Williams, 1976, (B), h.

Fig. 207 Amphidiadema denticulata Cookson and Eisenack, 1960a, (B), h.

Fig. 208 Bulbodinium seitzii O. Wetzel, 1960, (A), h.

Fig. 209 Ceratiopsis leptoderma Vozzhennikova, 1963, (A), h.

Fig. 210 Chatangiella niiga Vozzhennikova, 1967, (A), h.

Fig. 211 Deflandrea phosphoritica Eisenack, 1938, (A), h.

Fig. 212 Diconodinium multispinum (Deflandre and Cookson) Eisenack and Cookson, 1960, (B); a. h, b. s, ventral, c. s, dorsal.

Fig. 213 Hexagonifera glabra Cookson and Eisenack, 1961a, (B), h. 


\section{Deflandreaceae}
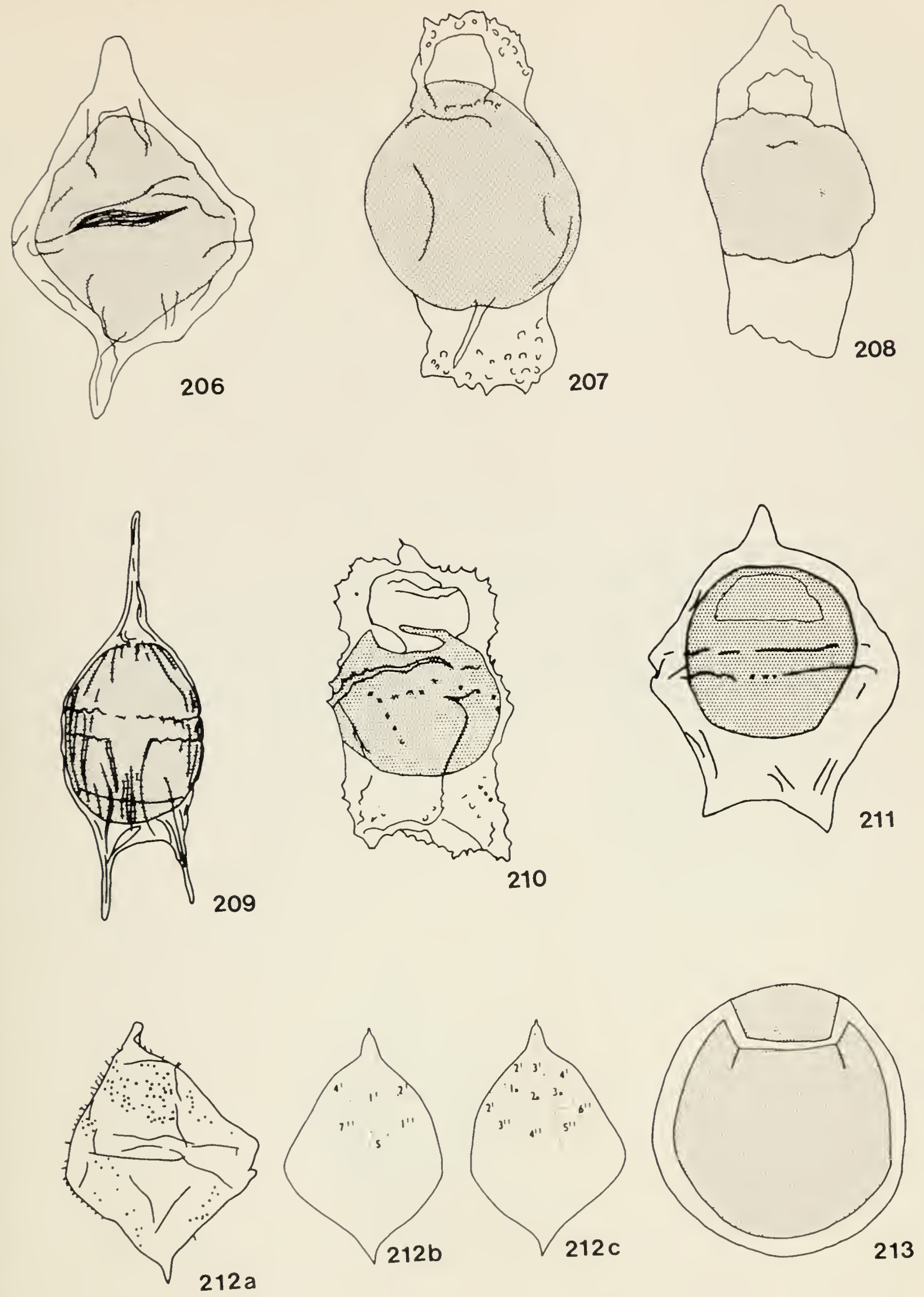


\section{Family Deflandreaceae (cont.)}

Fig. 214 Inversidinium exilimurum McLean, 1973b, (B), h.

Fig. 215 Isabelidinium korojonense (Cookson and Eisenack) Lentin and Williams, 1977a (B), h.

Fig. 216 Nelsoniella aceras Cookson and Eisenack, 1960a, (B), h.

Fig. 217 Palaeocystodinium golzowense Alberti, 1961, (A), h.

Fig. 218 Palaeohystrichophora infusorioides Deflandre, 1935, (C), h.

Fig. 219 Pseudodeflandrea gigantea Alberti, 1959, (A), h. 

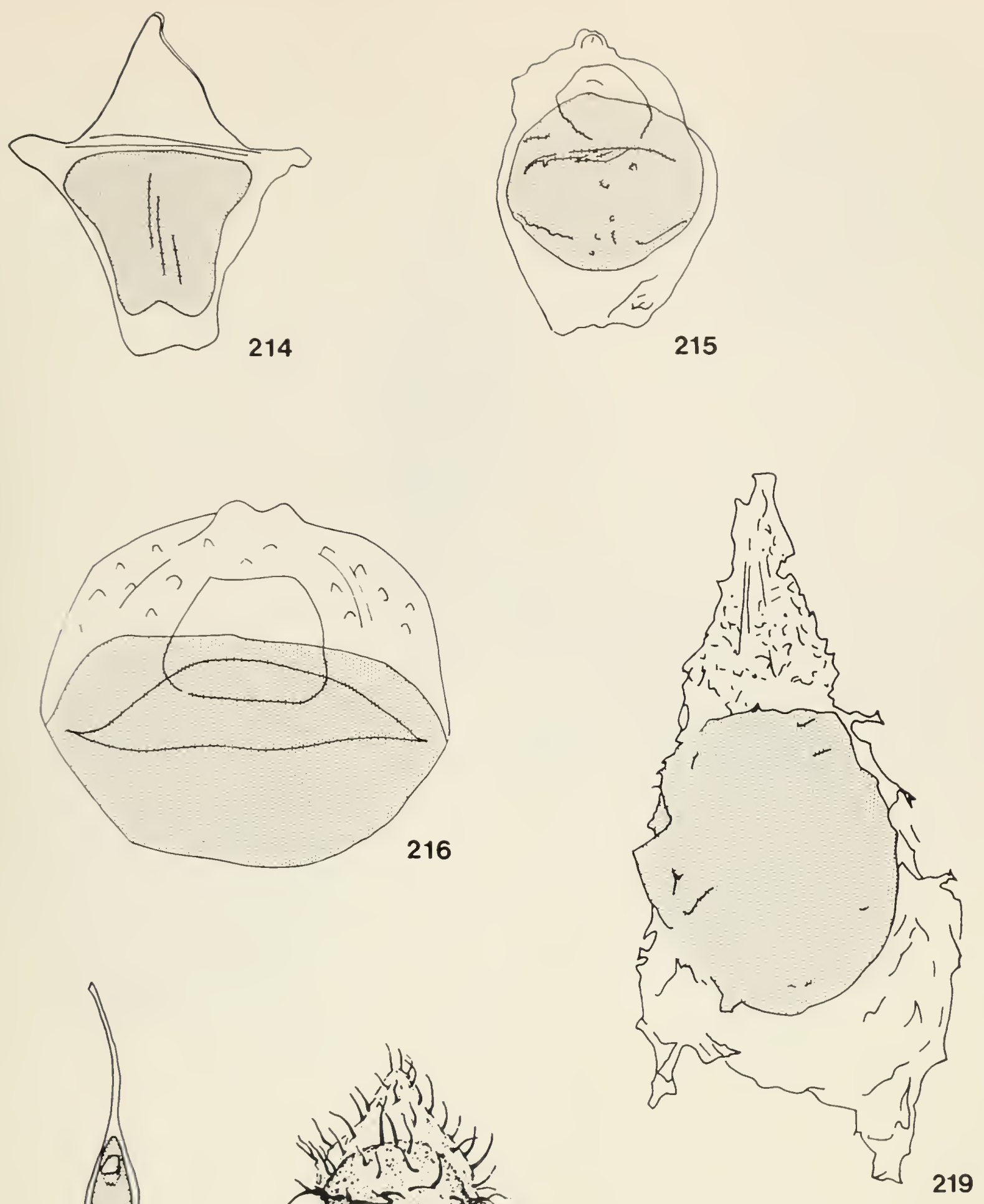

217

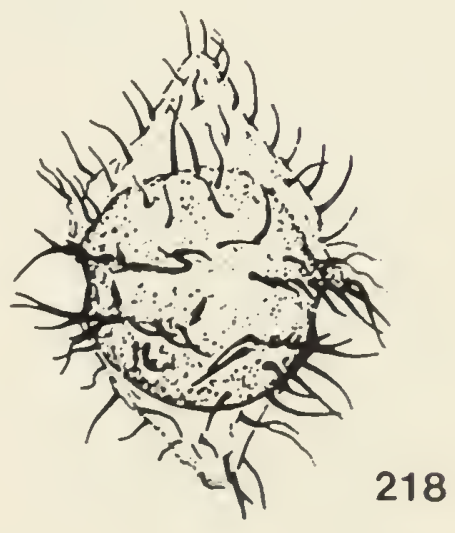


23. Family Deflandreaceae (cont.)

Fig. 220 Smolenskiella crassitheca Vozzhennikova, 1967, (C), h.

Fig. 221 Spinidinium styloniferum Cookson and Eisenack, 1962b, (B), h.

Fig. 222 Svalbardella cooksoniae Manum, 1960, (A), h.

Fig. 223 Trithyrodinium evittii Drugg, 1967, (B), h.

Fig. 224 Uvatodinium nasutum Vozzhennikova, 1963, (B), h.

Fig. 225 Xenikoon australis Cookson and Eisenack, 1960a, (B), h. 

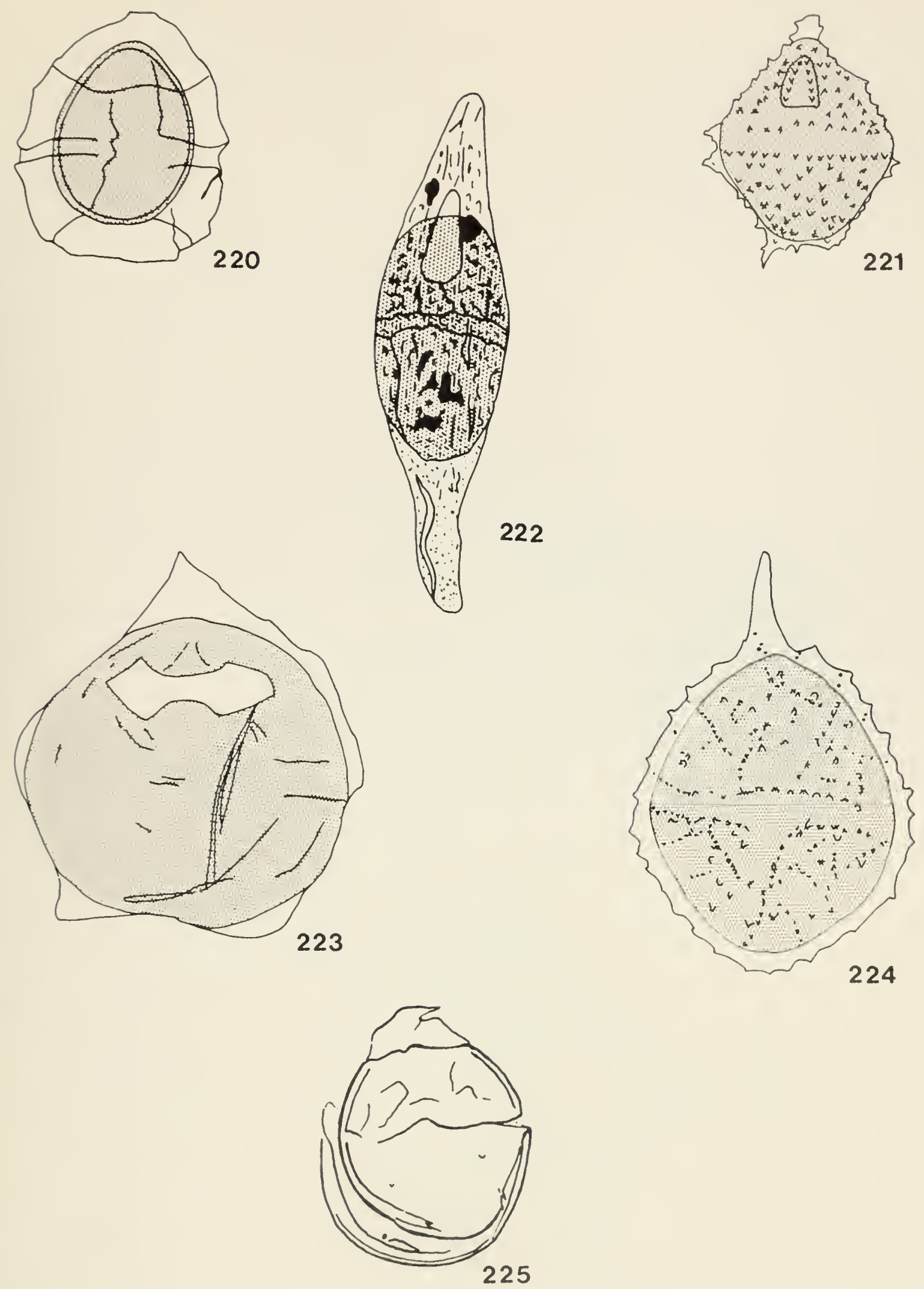
24. Family Palaeoperidiniaceae (226-234)

Fig. 226 Aquadulcum serpens Harland and Sarjeant, 1970, (C), h.

Fig. 227 Geiselodinium geiseltalense Krutzsch, 1962, (A), h.

Fig. 228 Ginginodinium spinulosum Cookson and Eisenack, 1960a, (B), h.

Fig. 229 Laciniadinium orbiculatum McIntyre, 1975, (B), h.

Fig. 230 Luxadinium primulum Brideaux and McIntyre, 1975, (C), p.

Fig. 231 Palaeoperidinium pyrophorum (Ehrenberg) Sarjeant, 1967, (B), a. h. 


\section{Palaeoperidiniaceae}

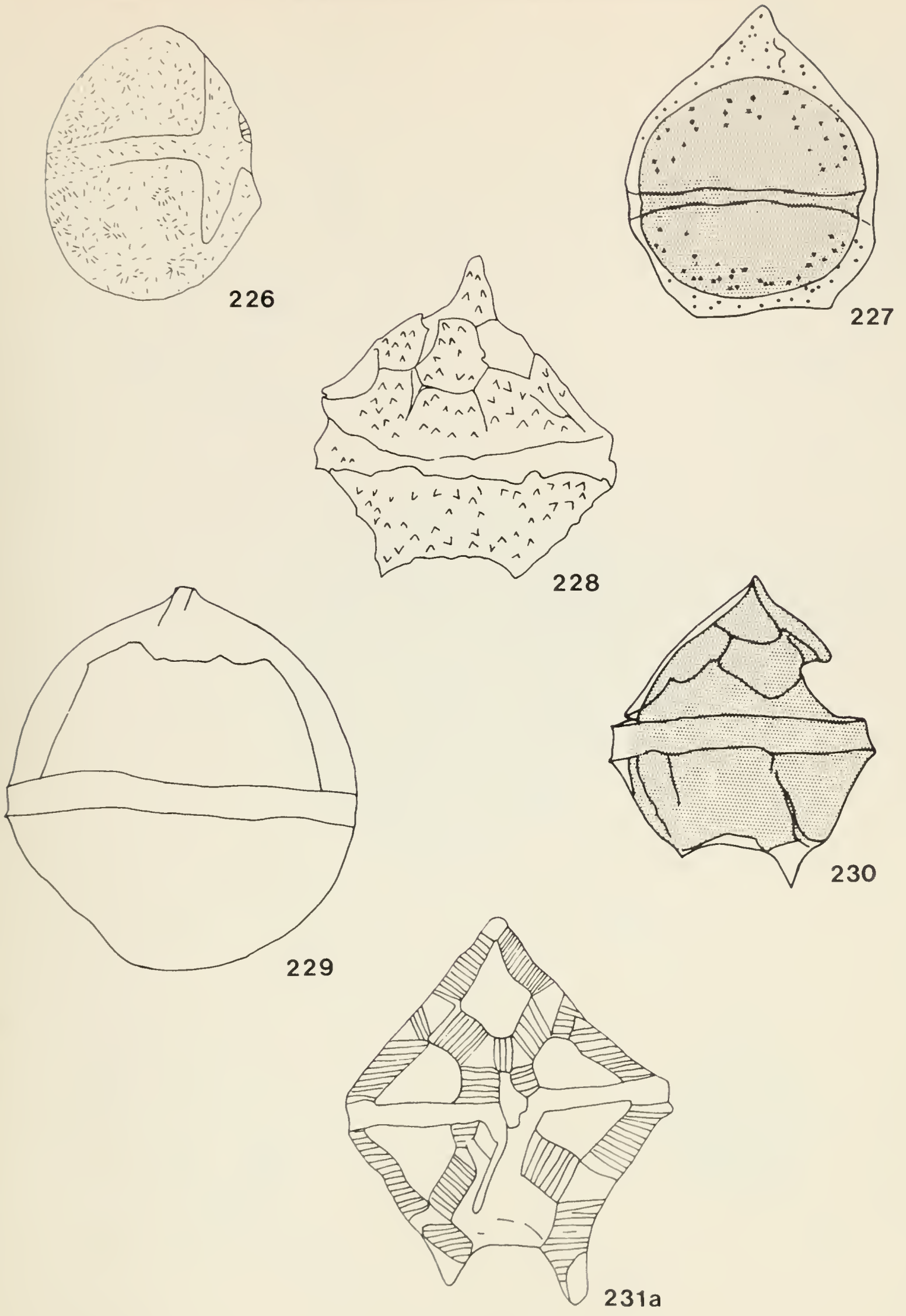




\section{Family Palaeoperidiniaceae (cont.)}

Fig. 231 (cont.) Palacoperidinium pyrophorum, (B), b. s. ventral, c. s, dorsal.

Fig. 232 Saeptodinium gravattense Harris, 1974, (B), h.

Fig. 233 Subtilisphaera senegalensis Jain and Millepied, 1973, (B), h.

Fig. 234 Teneridinium magnoides Krutzsch, 1962, (B), h. 

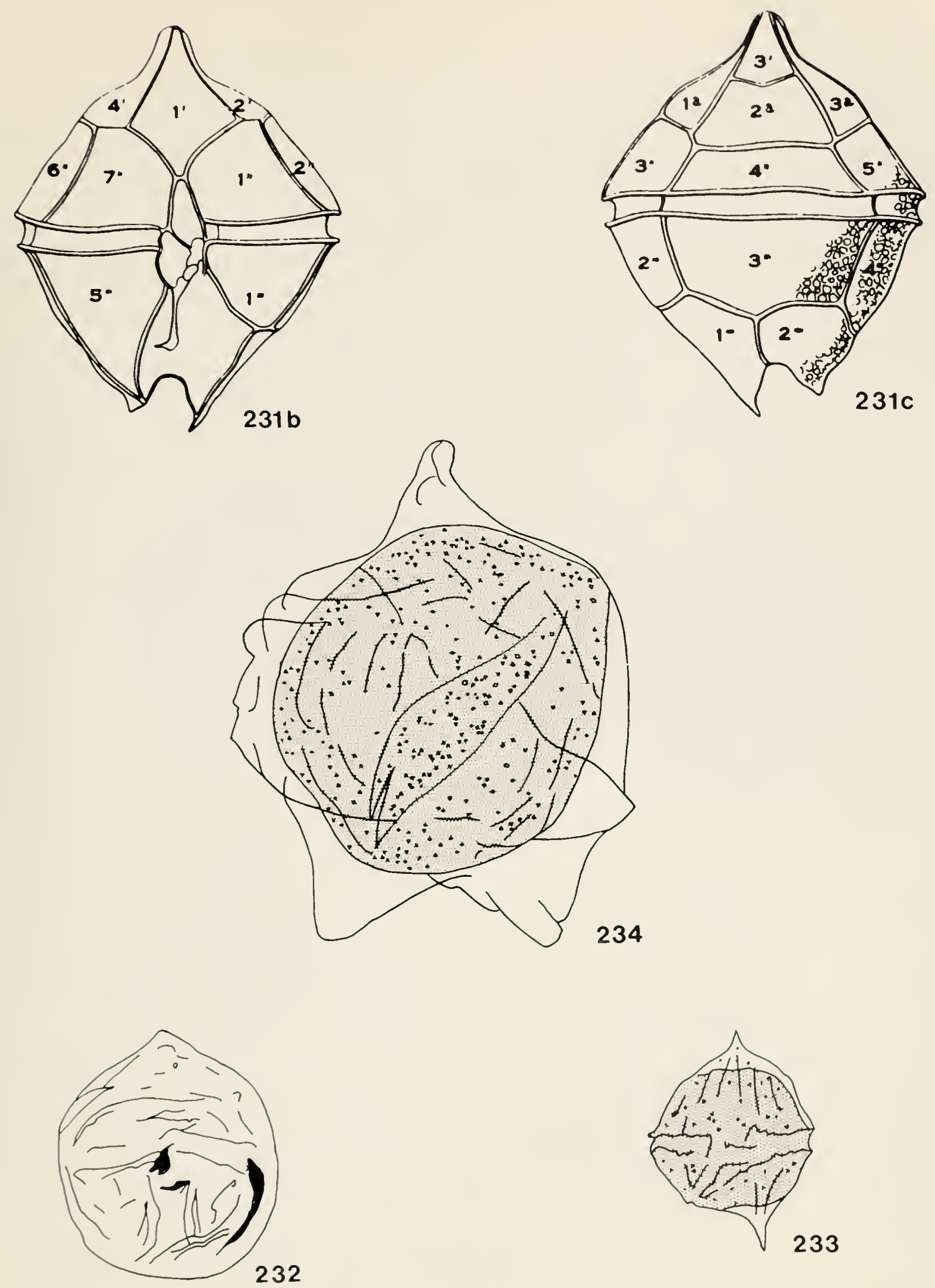


\section{Family Wetzeliellaceae (235-240)}

Fig. 235 Apectodinium homomorphum (Deflandre and Cookson) Lentin and Williams, 1977b, (B), h. Fig. 236 Dracodinium solidum Gocht, 1955, (B), h.

Fig. 237 Kisselovia ornata Vozzhennikova, 1967, (C), h.

Fig. 238 Rhombodinium draco Gocht, 1955, (A), h.

Fig. 239 Wetzeliella articulata Eisenack, 1938, (A), h.

Fig. 240 Wilsonidium rabulatum (Wilson) Lentin and Williams, 1976, (A), h. 


\section{Wetzeliellaceae}

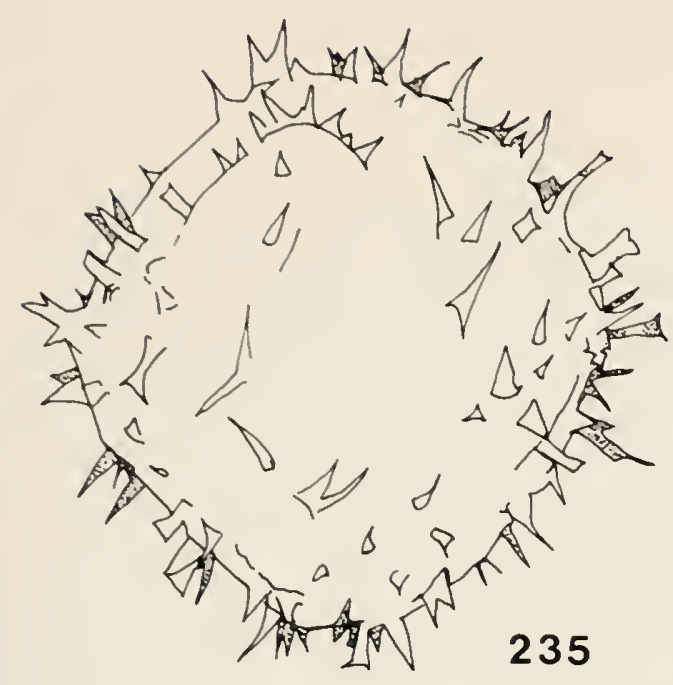

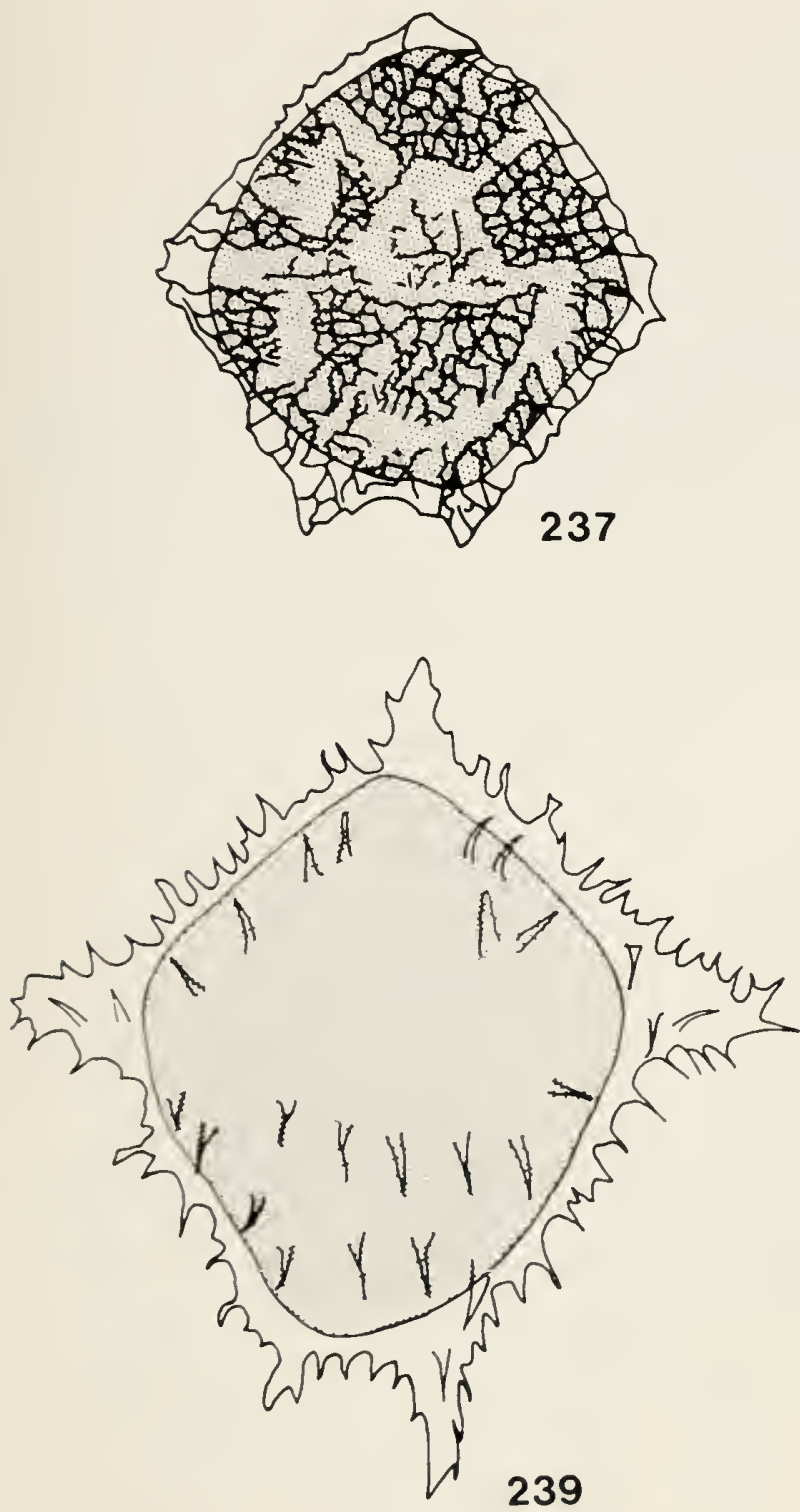
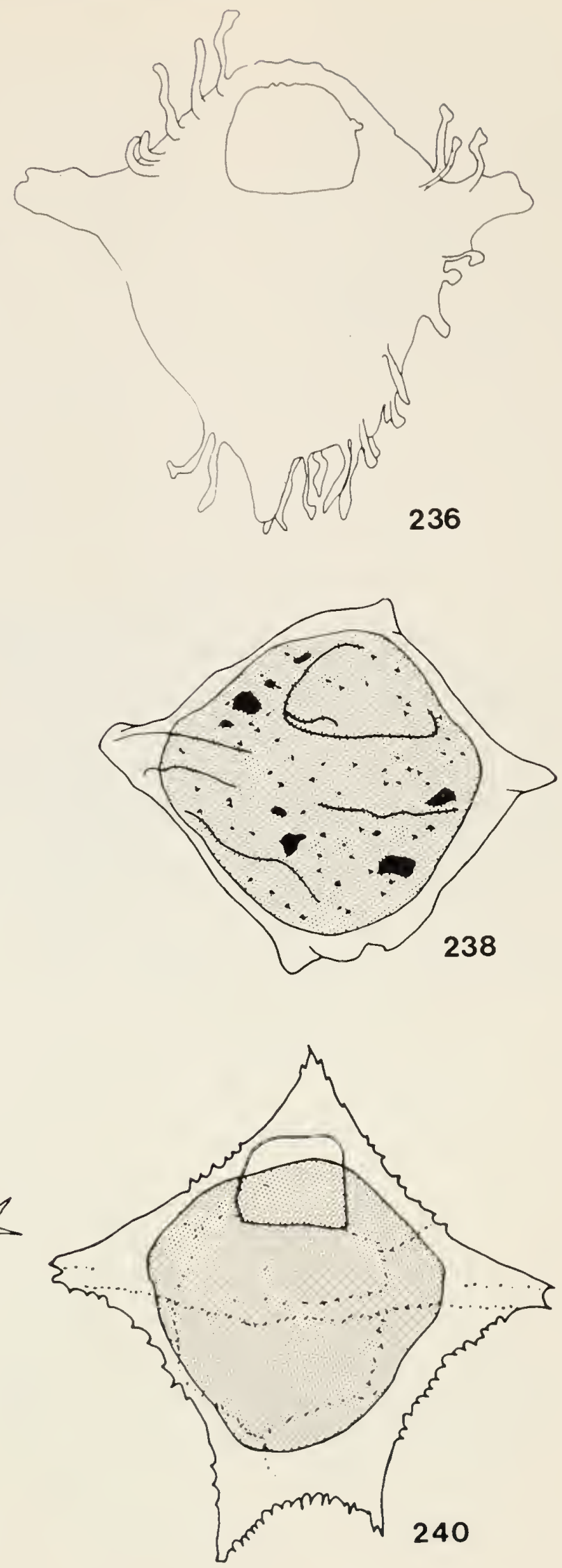


\section{Family Phthanoperidiniaceae (241-255)}

Fig. 241 Andalusiella mauthei Riegel, 1974, (A), s; a. dorsal, b. ventral.

Fig. 242 Dioxya armata Cookson and Eisenack, 1958, (B), h.

Fig. 243 Leipokatium invisitatum Bradford, 1975, (B), h.

Fig. 244 Lejeunecysta hyalina (Gerlach) Artzner and Dörhöfer, 1978, (A), h; a. dorsal, b. ventral.

Fig. 245 Maduradinium pentagonum Cookson and Eisenack, 1970, (A), h.

Fig. 246 Muiradinium dorsispirale (Churchill and Sarjeant) Harland and Sarjeant, 1970, (C), h; a. ventral, b. dorsal. 


\section{Phthanoperidiniaceae}
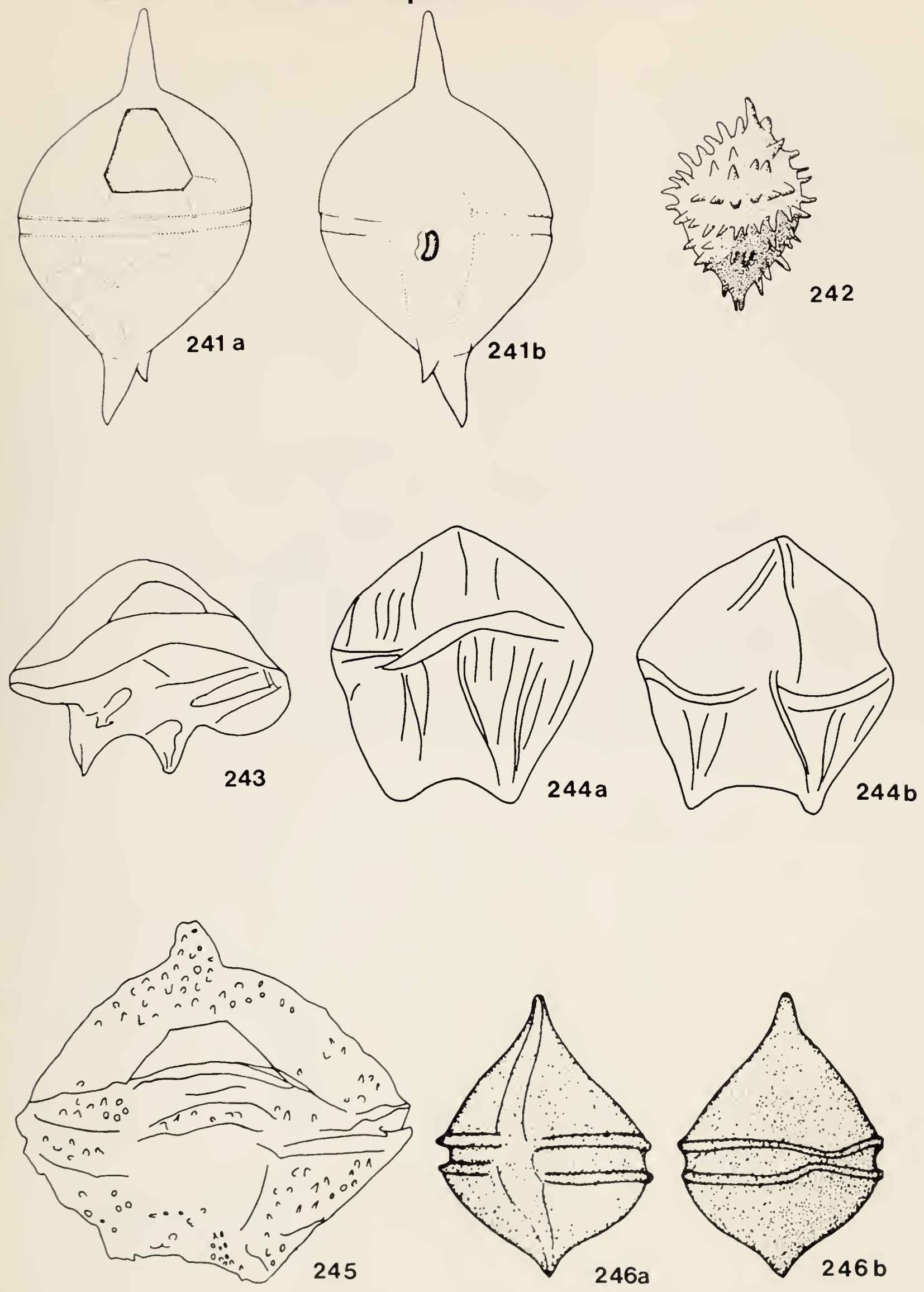


\section{Family Phthanoperidiniaceae (cont.)}

Fig. 247 Multispinula quanta Bradford, 1975, (B), h.

Fig. 248 Omanodinium alticinctum Bradford, 1975, (A), h.

Fig. 249 Phthanoperidinium amoenum Drugg and Loeblich, 1967, (C), h; a. dorsal, b. ventral.

Fig. 250 Pyxidiella pandora Cookson and Eisenack, 1958, (C), h.

Fig. 251 Selenopemphix nephroides Benedek, 1972, (B), h.

Fig. 252 Soaniella granulata Vozzhennikova, 1967, (B), h.

Fig. 253 Stelladinium readii Bradford, 1975, (B), h.

Fig. 254 Sumatradinium hispidum (Drugg) Lentin and Williams, 1976, (B), h.

Fig. 255 Vozzhennikovia apertura (Wilson) Lentin and Williams, 1976, (B), h. 

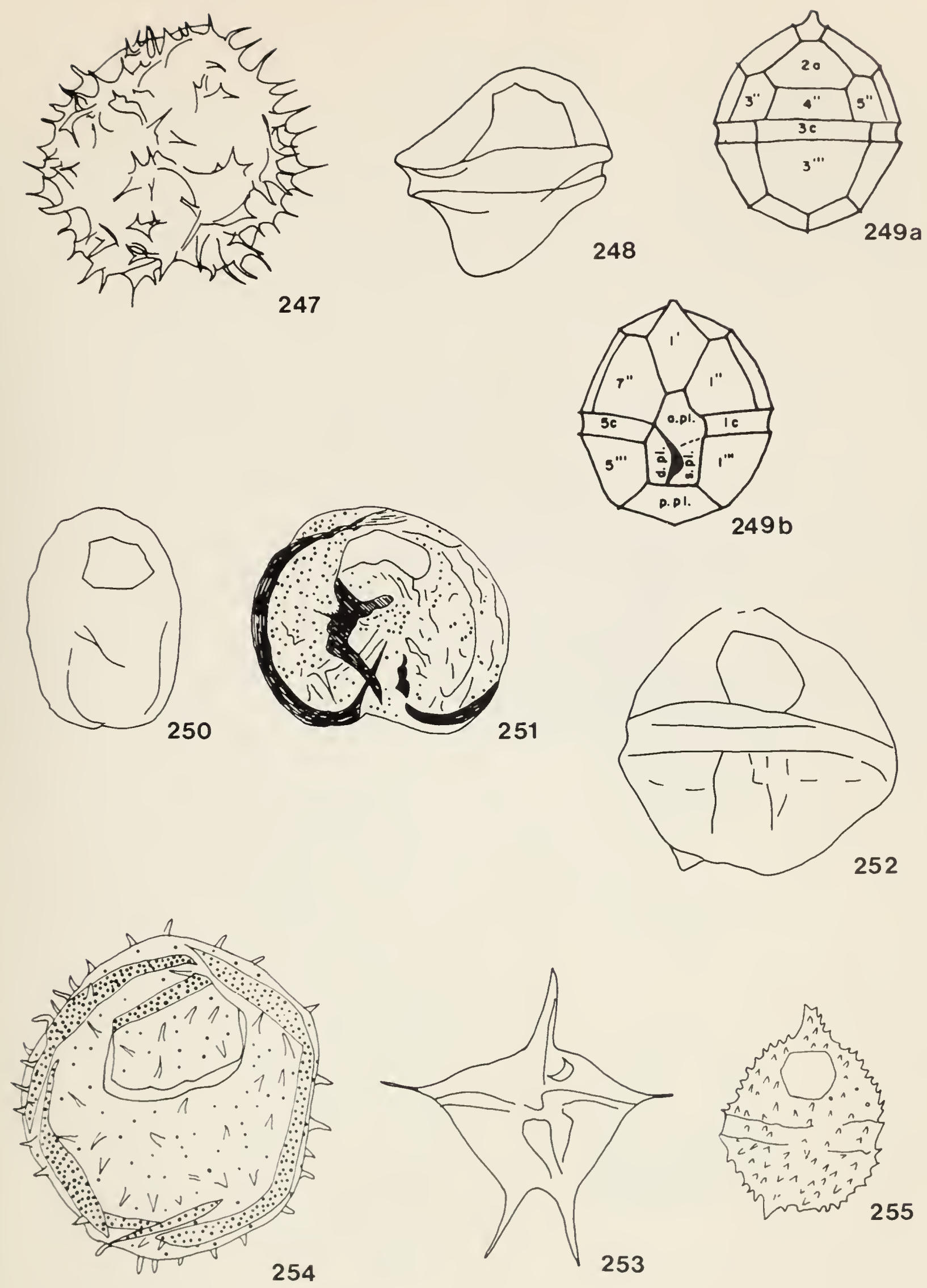
27. Family Ovoidiniaceae (256-258)

Fig. 256 Ascodinium acrophorum Cookson and Eisenack, 1960a, (B), h.

Fig. 257 Balcattia cirrifera Cookson and Eisenack, 1974, (B), h.

Fig. 258 Ovoidinium verrucosum (Cookson and Hughes) Davey, 1970, (B), h.

\section{Family Ceratocoryaceae (259-261)}

Fig. 259 Pentadiniurn laticinctum Gerlach, 1961, (A), s; a. apical, b. antapical.

Fig. 260 Romanodinium areolatum Baltes, 1971, (B), h.

Fig. 261 Thalassiphora pelagica (Eisenack) Eisenack and Gocht, 1960, (A), p. 


\section{Ovoidiniaceae}
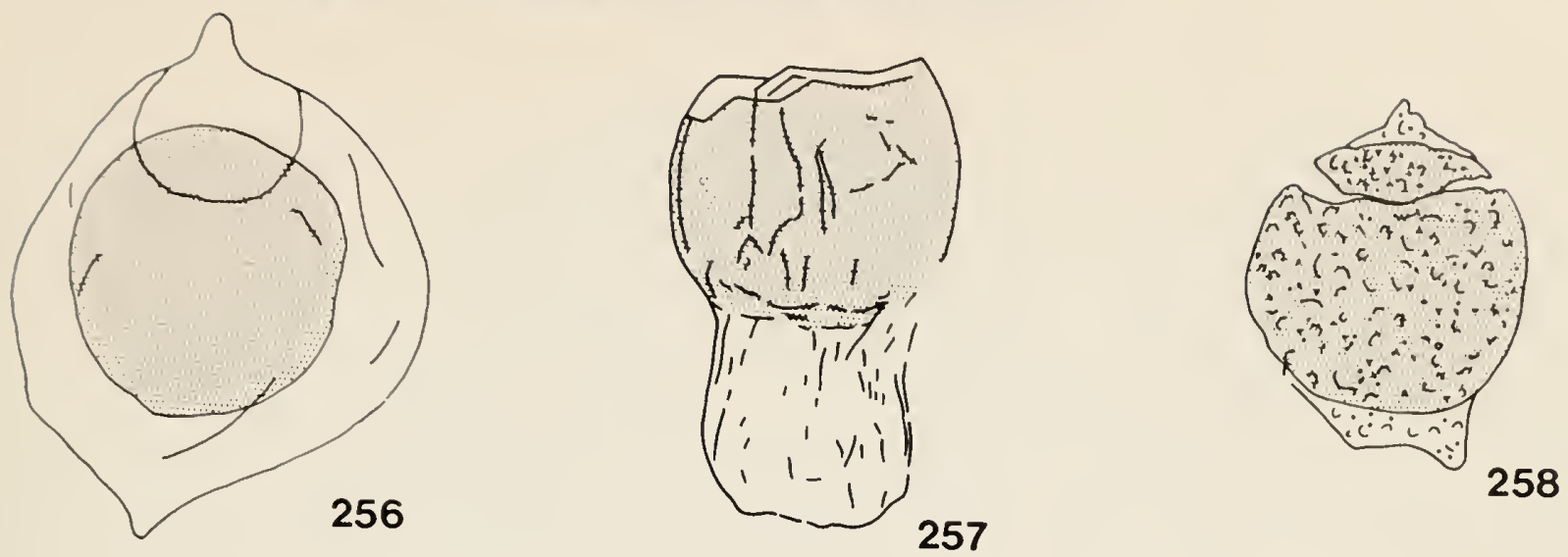

28. Ceratocoryaceae
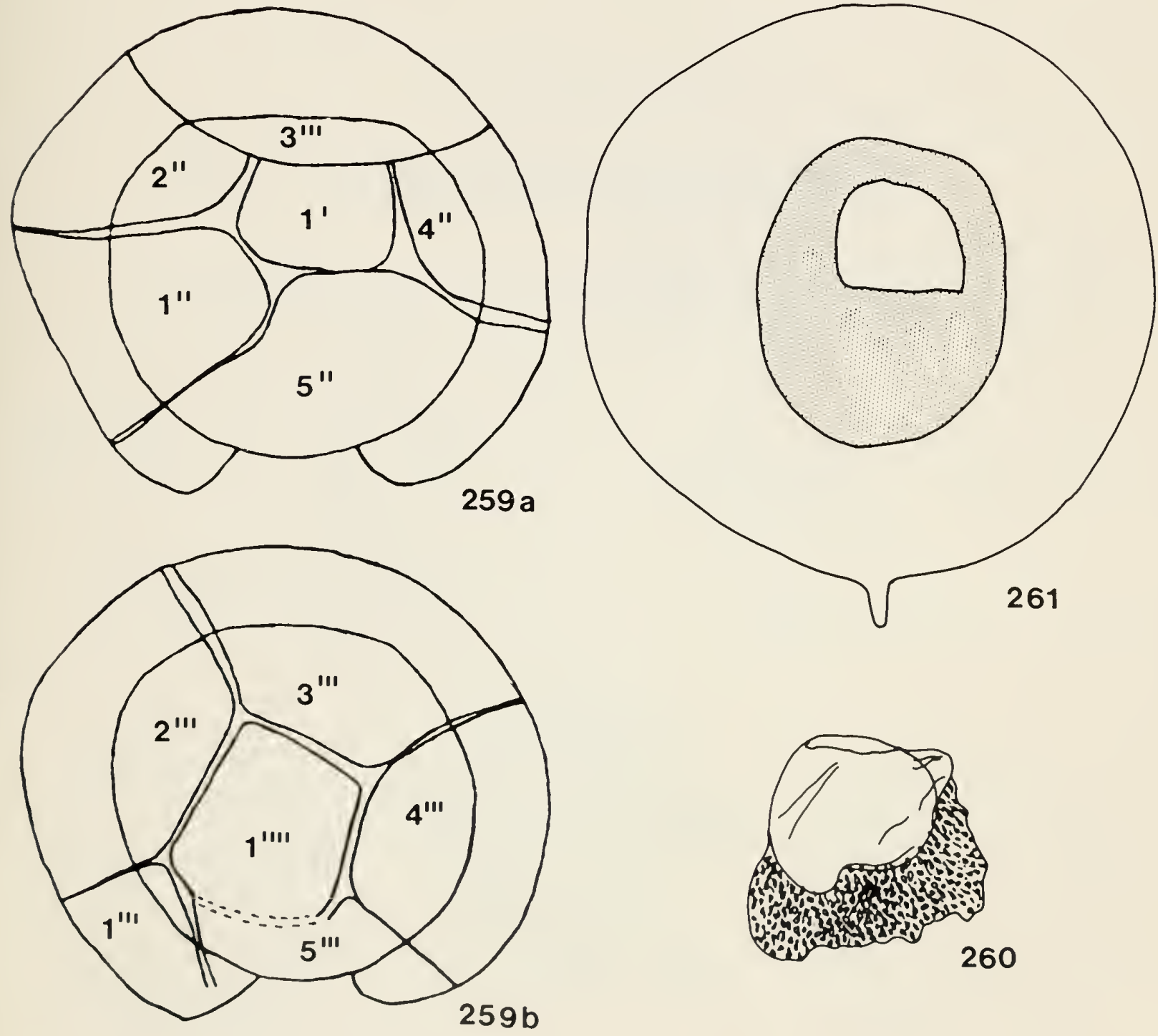
29. Family Pyrophacaceae (262)

Fig. 262 Tuberculodinium vancampoae (Rossignol) Wall, 1967, (B), s.

30. Family Heteraulacacystaceae (263-265)

Fig. 263 Dinopterygium cladoides Deflandre, 1935, (B), h.

Fig. 264 Heteraulacacysta campanula Drugg and Loeblich, 1967, (B), h; a. dorsal, b. ventral.

Fig. 265 Tubidermodinium sulcatum Morgenroth, 1966, (B), h; a. ventral, b. dorsal. 


\section{Pyrophacaceae}

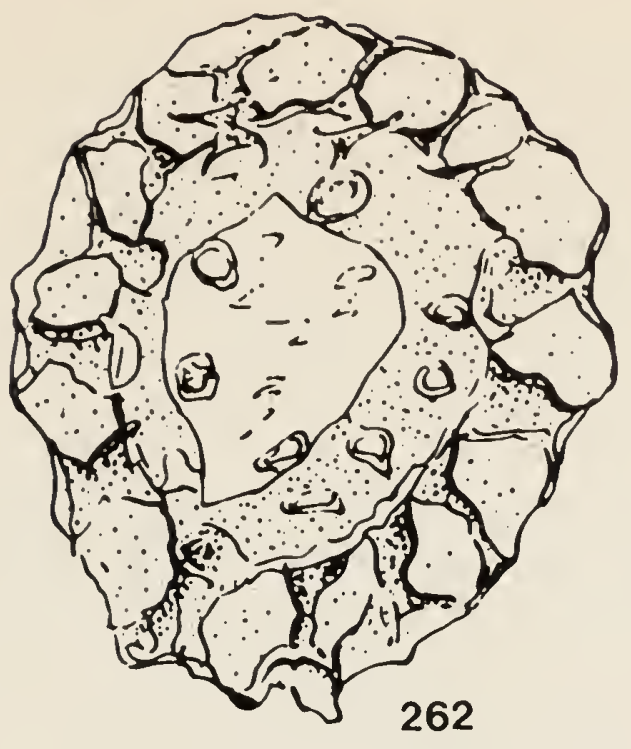

\section{Heteraulacacystaceae}
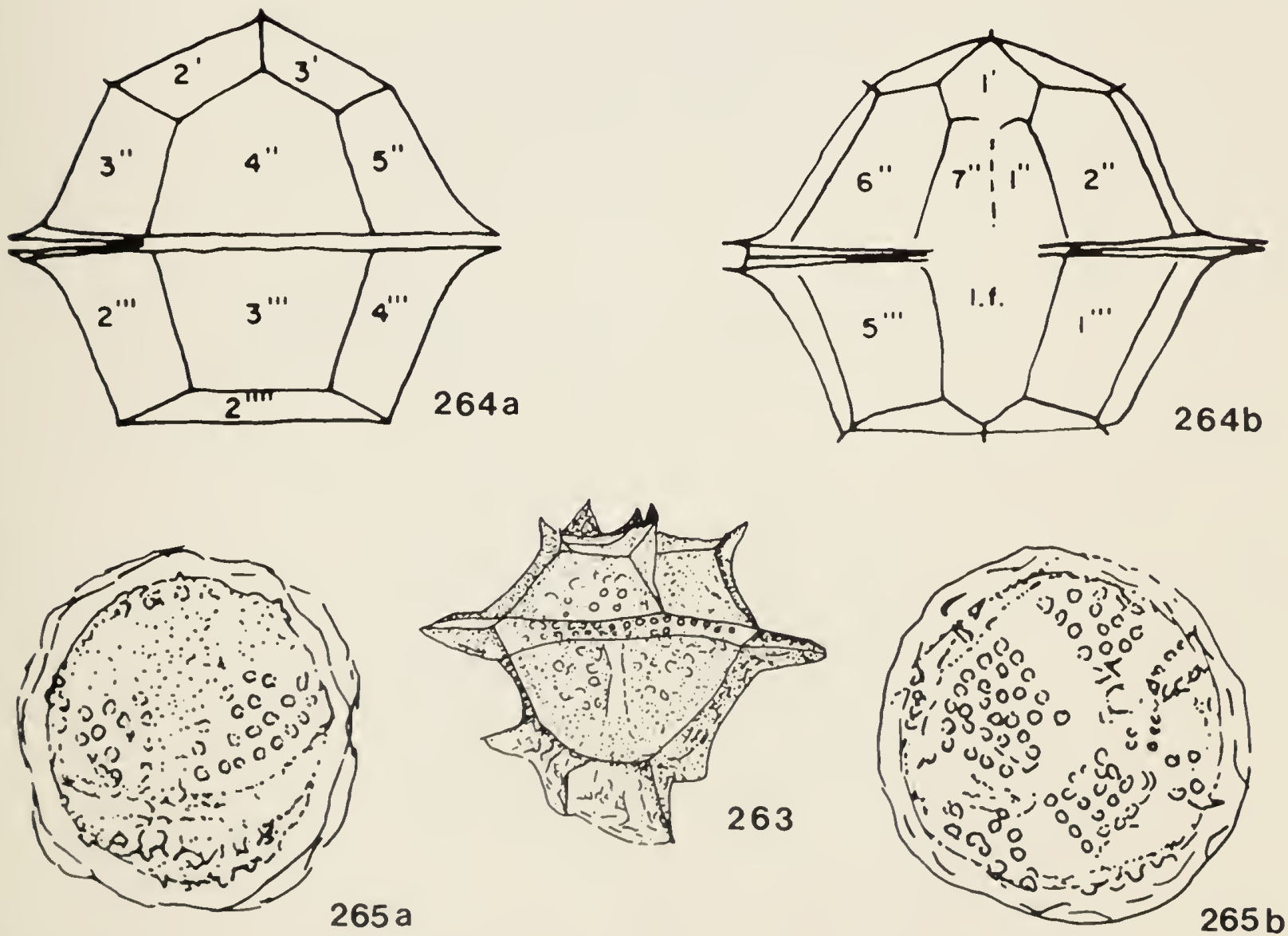
31. Family Microdiniaceae (266-267)

Fig. 266 Cladopyxidium septatum McLean, 1972, (A), h; a. ventral, b. dorsal. Fig. 267 Microdinium ornatum Cookson and Eisenack, 1960a, (C), h.

32. Family Nannoceratopsaceae (268)

Fig. 268 Nannoceratopsis pellucida Deflandre, 1938, (B), h.

\section{Family Dinogymniaceae (269)}

Fig. 269 Dinogymnium acuminatum Evitt et al., 1967, (B), h; a. dorsal, b. ventral. 


\section{Microdiniaceae}
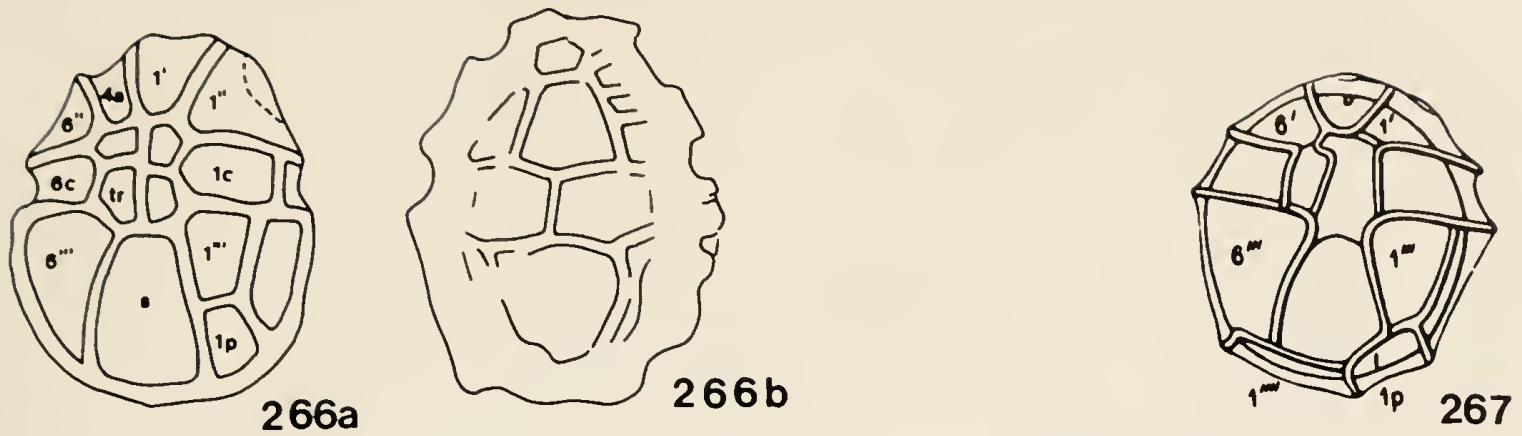

32. Nannoceratopsaceae

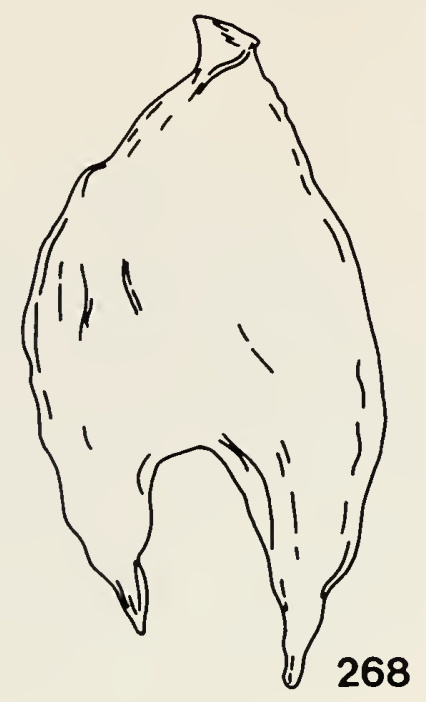

33. Dinogymniaceae
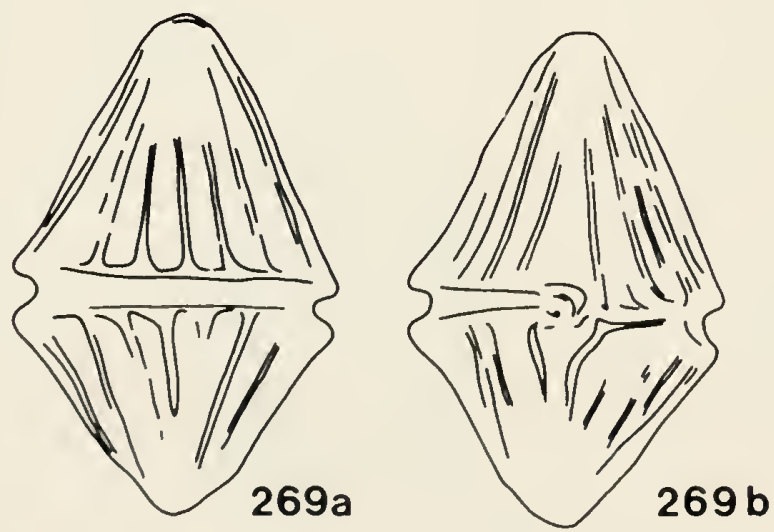


\section{Incertae familiae}

Fig. 270 Anthosphaeridium convolvuloides Cookson and Eisenack, 1968, (B), h.

Fig. 271 Ascostomocystis hydria Drugg and Loeblich, 1967, (B), h.

Fig. 272 Cometodinium obscurum Deflandre and Courteville, 1939, (B), h.

Fig. 273 Fromea amphora Cookson and Eisenack, 1958, (B), h.

Fig. 274 Muiriella plioplax Churchill and Sarjeant, 1963, (B), h; a. ventral, b. dorsal.

Fig. 275 Paralecaniella indentata (Deflandre and Cookson) Cookson and Eisenack, 1970, (B), a. s, b. h.

Fig. 276 Phanerodinium cayeuxii (Deflandre) Deflandre, 1937, (D), h; a. h, dorsal, b. p, dorsal. 


\section{Incertae familiae}
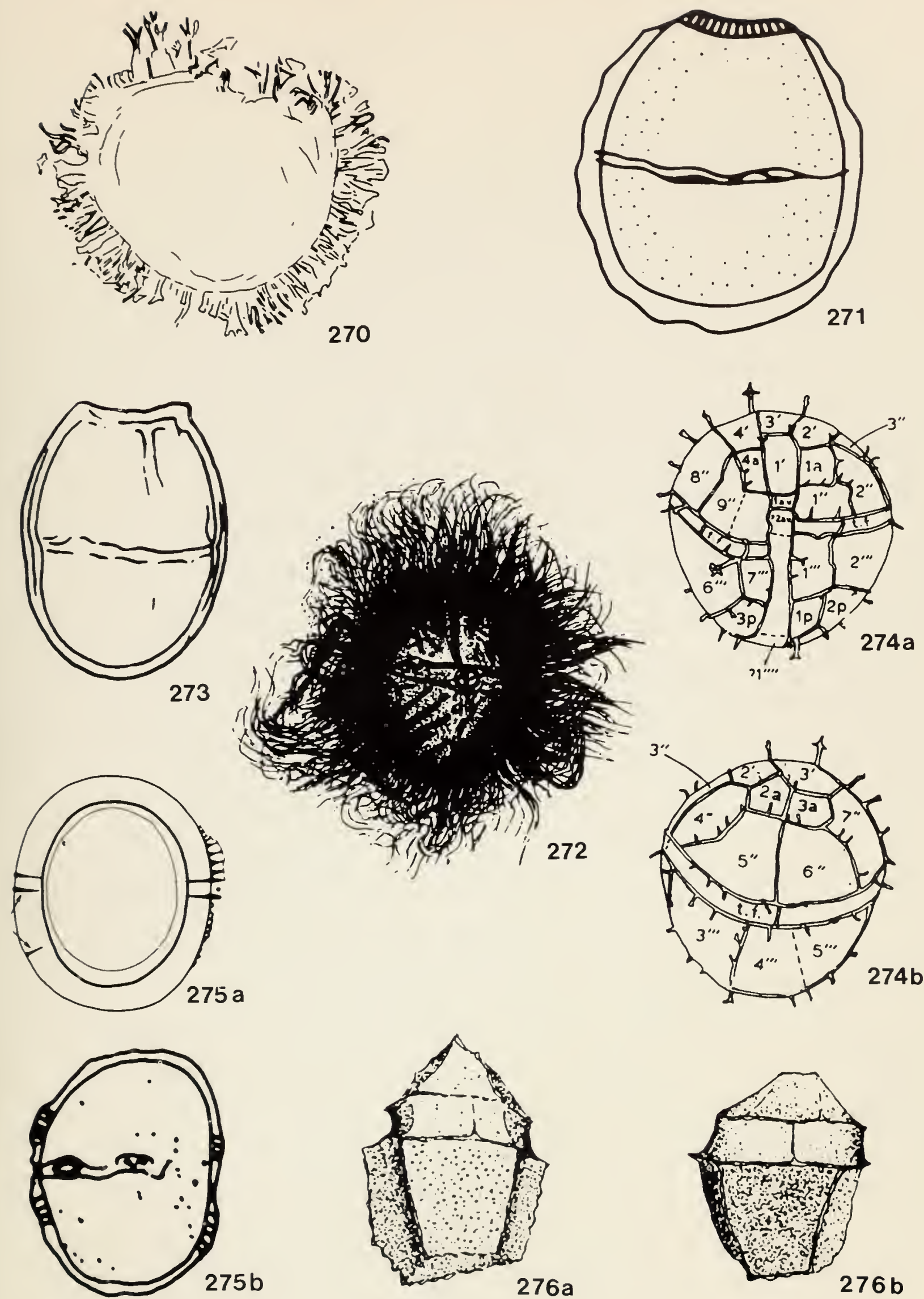


ISBN 0-88854-237-2

ISSN 0082-5093 